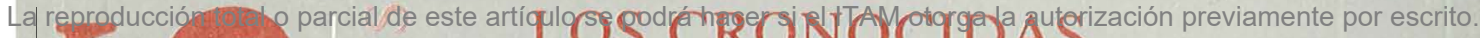

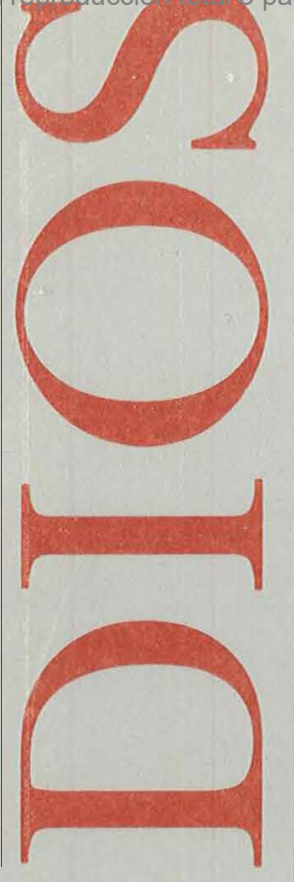

\title{
Denis Grozdanovitch
}

AMÉRICA: HISTORIA Y

CONMEMORACIÓN

Mauricio Tenorio

HABERMAS: LEGITIMIDAD Y

DISCURSO PRÁCTICO

Enrique Serrano

LA UNIVERSIDAD:

CONCIENCIA CRÍTICA

Carlos De la Isla

EL POEMA COMO SEMIÓTICA CONNOTATIVA

Alberto Perrone

LA SUBJETIVIDAD Y EL

CUERPO EN MERLEAU-PONTY

Eduardo González Di Pierro

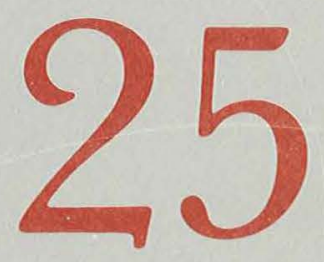

VERANO 1991

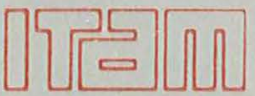




\section{SEGULTEX \\ Una empresa con \\ trayectoria profesional}

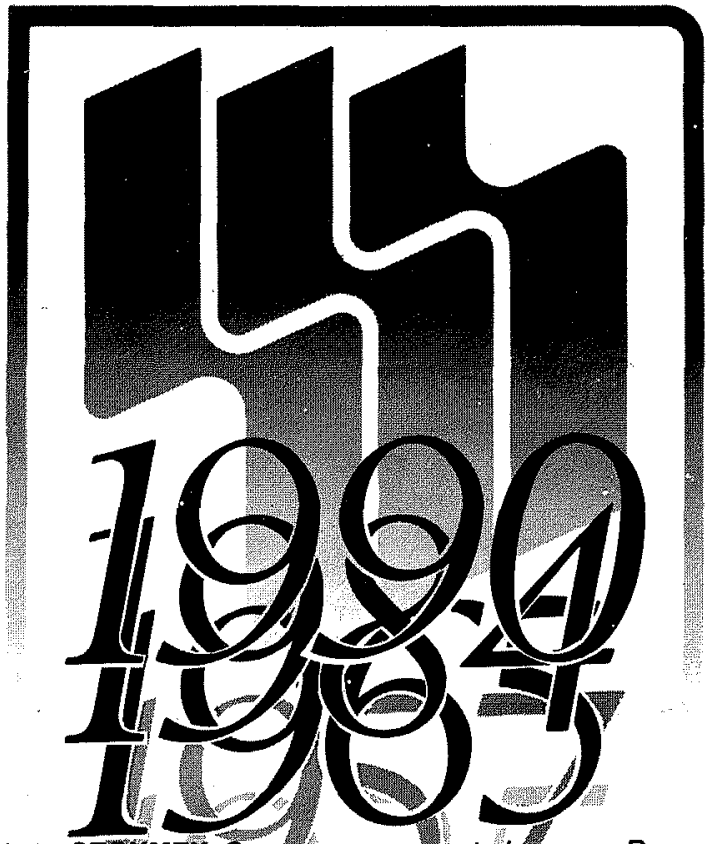

Desde 1935 SECUMEX, Seguros de México, S.A. ha estado

que usted merece. Para ello, por siempre ss ha preparado técnica presente en la sociodad niexican a thmanamente ofreciendo lo mejor proporcionando protección en el de SEGUMEX:

área de seguros.

Durante más de 50 años SEGUMEX Trabajo y atención profesional. ha trabajado para brindar e/ servicio

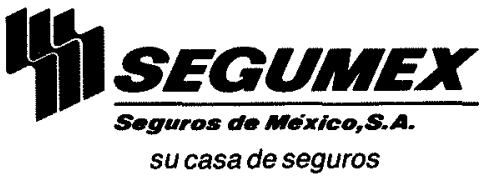




\section{E S T U D I O S}

FILOSOFÍA * HISTORIA * LETRAS

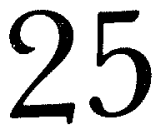

VERANO 1991

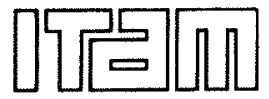


RECTOR

Javier Beristain

DIRECTOR DE LA DIVISIÓN ACADÉMICA DE ESTUDIOS GENERALES E INTERNACIONALES

Rodolfo Vázquez

\author{
JEFE DEL DEPARTAMENTO ACADEMICO \\ DE ESTUDIOS GENERALES \\ Carlos de la Isla
}




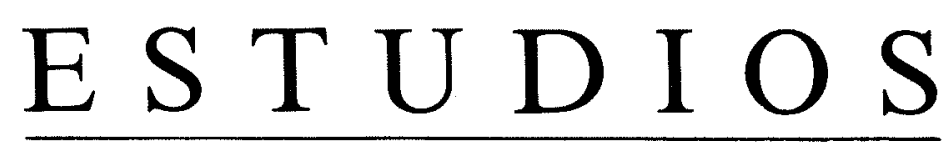

FILOSOFÍA * HISTORIA * LETRAS

Publicación trimestral del Departamento Académico de Estudios

Generales del Instituto Tecnológico Autónomo de México

\title{
25
}

VERANO 1991

\author{
DIRECTOR \\ Julián Meza \\ JEFE DE REDACCIÓN \\ Alberto Sauret \\ SECRETARIA DE REDACCIÓN \\ Nora Pasternac
}

ADMINISTRADOR

José Barba

\section{CONSEJO EDITORIAL}

Margarita Aguilera, Luis Astey, José Ramón Benito, Ignacio Díaz de la Serna, Antonio Díez, Rafael Fernández de Castro, Raúl Figueroa, Luz Elena Gutiérrez de Velasco, Marcos Kaplan, Maribeth Kauss, Carlos Mc Cadden, Laura O’Dogherty, José Manuel Orozco, Carmen Sánchez, Jorge Serrano, Julia Sierra, Reynaldo Sordo, Emilio Zebadúa 


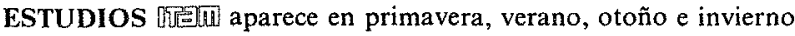

Precio por ejemplar: $\$ 11,500$ M.N. D.F. Extranjero 10 dól. Suscripción anual (4 números): $\$ 40,000$ M.N. D.F. $\$ 45,000$ M.N. interior de la República; 35 dól.

\section{Correspondencia:}

Instituto Tecnológico Autónomo de México

Departamento Académico de Estudios Generales

Río Hondo 1, Tizapán, San Angel

01000 , México, D.F.

Tels. 5509300 ext. 443 y 328

\section{ISSN 0185-6383}

Licitud de título No. 2512

Licitud de contenido No. 1607

Diseño: Annie Hasselkus

Distribución: Difesa (locales cerrados e interior de la República)

Amado Paniagua 47 bis, Col. Moctezuma

15500 México D.F. Tels. 7846696 y 7846722

Promoción y publicidad: Martha Reverdito

Tipografía en laser: Alma Camacho (ITAM)

Formación negativos, impresión y acabado: Multidiseño Gráfico, S.A.

Oaxaca núm. 1, San Jerónimo Aculco, México, D.F. C.P. 01000

Tel. $6525211 \quad 6525581 \quad$ FAX 6523951 


\section{ÍNDICE}

TEXTOS

LOS CRONOCIDAS

Denis Grozdanovitch

AMÉRICA: HISTORIA Y CONMEMORACIÓN Mauricio Tenorio

HABERMAS: LEGITIMIDAD Y DISCURSO

PRÁCTICO

Enrique Serrano

LA UNIVERSIDAD. CONCIENCIA CRÍTICA

Carlos De la Isla

EL POEMA COMO SEMIÓTICA CONNOTATIVA

NOTAS

LA SUBJETIVIDAD Y EL CUERPO EN MERLEAU-PONTY

Eduardo González Di Pierro

SADAM EN COLONA

Ghessan Salame

LOS MAGREBÍES DE FRANCIA Y LA GUERRA

DEL GOLFO

Driss el Yazami 


\section{RESEÑAS}

LEE SMITH, Damas tiernas y hermosas

Julián Meza

TERESA AVELEYRA-SADOWSKA, Hasta la tercera y cuarta generación

Luz María Silva

ZAMIATIN, Nosotros

Julián Meza

G. VATTIMO y otros, El torno a la posmodernidad

Alberto Sauret 


\section{LOS CRONOCIDAS*}

\section{Denis Grozdanovitch**}

Boswell: Acabamos por hartarnos de estar ociosos. Johnson: Ello ocurre, señor, porque necesitamos la companía de los otros, que están ocupados; pero si todos estuviéramos ociosos, no habría hastio; nos distraeríamos unos con otros.

\section{Muy a menudo voy por la tarde a la} sesión de las cuatro de la cinemateca de Chaillot. Allí encuentro regularmente a la misma pandilla de viejos cinéfilos con la cual no me mezclo (al menos todavía), pero observo subrepticiamente. Para ellos, habría que inventar una nueva expresión equivalente a "ratón de biblioteca": acaso ratón calvo de cinemateca... Barbudos, descuidados, cubiertos con sus viejos abrigos deformados salpicados de briznas de tabaco, en la boca pipas o colillas a medio apagar balanceándose en el labio inferior, oprimidos por las bufandas raídas y sucias que se enroscan alrededor de una corbata descolorida, mal vestidos con su pantalón informe de donde salen, en la cintura, faldones de camisa de otra época, provistos casi todos de portafolios de cuero ajados y abultados, atiborrados de periódicos, de revistas especializadas, de libros semirrotos, de cuadernos desportillados, y muy a menudo también, de una gran cantidad de objetos más o menos heteróclitos del tipo de soldados de plomo o trenes eléctricos en miniatura -que cambian y trafican febrilmente antes y después de las sesionesellos llegan cotidianamente puntuales a la cita. Es díficil saber si desempeñan un oficio o alguna función social; todos parecen disponer libre-

*** Traducción de Nilda Ibarguren.

** Escritor francés. 
Denis Grozdanovitch

mente de su tiempo. Casi todos son muy pálidos y se adivina que pasan la mayor parte de su tiempo metidos en las bibliotecas, en los baratillos y en las salas de cine. A fuerza de estar confrontados con los caracteres de imprenta y con la reverberación de los proyectores de ilusiones, sus ojos están rojos, dilatados, perdidos en el vacío. A la luz del día, sobre todo si hay sol, es fácil advertir que su mirada no se adapta al exterior. Después de estas sesiones, ellos regresan tal cual, del brazo, conversando en voz baja como conspiradores a propósito de las diferentes versiones (ellos las conocen todas), de los nombres de los actores, de sus méritos respectivos, volviéndose a veces vehementes, irritándose y defendiendo con una inspiración lírica que ya no controlan, el prestigio de uno de sus favoritos denigrado por los compañeros -su portafolios bamboleando en una mano, la visera de su gorra inclinada sobre los ojos ligeramente extraviados a fin de evitar la excesiva claridad de lo real. Se adivina que se dirigen hacia cuartos abuhardillados -colmados de libros, de discos, de pequeños objetos decorativos, de fotos, de periódicos y de pinturas apilados en los rincones-donde rehogan, en una sartén completamente negra y que huele a grasa, sobre un viejo hornillo que han heredado, su comida de viejos maniáticos marginales. Entre ellos, algunas mujeres: delgadas, de rostros demacrados, con lentes, sus ojos miopes perdidos en un halo donde vaga su mirada extraviada... Casi no hablan, apartándose siempre, y desaparecen de pronto tan discretamente como aparecieron, sombras clandestinas de la existencia...

Se siente que la mayoría de ellos no se ha confrontado con las peripecias o las turbulencias eventuales de la vida sino a través de la refracción de lo ficticio: son amantes de sueños...

Tomo conciencia de que estas gentes son casi las mismas que venían a jugar al billar, a las cartas y al ajedrez a la academia Roger-Conti, en la plaza de Termes, en los tiempos en que yo pasaba allí mis tardes. Me acuerdo de esas largas horas indefinidamente prolongadas, bajo la pobre luz de las lámparas colgadas muy alto, en medio del humo de los cigarros -que, en cada mesa y en los ceniceros colocados sobre el borde de los billares, parecían otros tantos minúsculos fuegos propiciatorios dedicados al dios de la suerte- en el semisilencio murmurante, punteado a intervalos regulares por los altercados de los jugadores de tarot y por el 


\section{LOS CRONOCIDAS}

ligero entrechoque de las bolas brillantes sobre el paño verde, entre esta asamblea de desclasados excéntricos, de edades y extracciones variadas: jóvenes desocupados cínicos o resignados, jubilados planificadores y reaccionarios, proxenetas jactanciosos e hipócritas, pequeños jugadores profesionales que van viviendo de sus ganancias, taimados y estafadores, rentistas plácidos y descreídos, vagos indolentes y filósofos... todos ligeramente chiflados, peculiares, provistos de extravagantes manías, de molestos tics nerviosos, adornando sus monólogos egocéntricos con expresiones curiosas fabricadas de cualquier modo, pescadas aquí y allá al azar de sus lecturas autodidactas; disimulando todos más o menos bien un secreto orgullo megalomaníaco que se revelaba en ciertos momentos de crisis: si una de sus victorias era discutida en el plano táctico, si su vencedor eventual exhibía una satisfacción demasiado evidente, o si una conversación cualquiera venía a tocar una de sus manías favoritas. Ocasiones gracias a las cuales se desencadenaba una serie de sarcasmos confusos que ellos creían brillantes, una serie de sentencias abstrusas que imaginaban definitivas, adornando el conjunto con consideraciones generales pedantes que sobrepasaban ampliamente su objeto y de las cuales no se comprendía ni jota, pero cuya rara pertinencia se podía presentir por las risitas burlonas que subrayaban sus momentos culminantes-ellos revelaban de repente (la mayoría de las veces con gran estupefacción del recién llegado que había tenido la audacia de contrariar su estrategia preferida, sin ponerse siquiera en guardia, y de "hacerlos polvo" con toda inocencia...) su inmensa piedad por la multitud de quienes habían cometido demasiado a menudo el funesto error de desdeñar su punto de vista.

Mis compañeros de ajedrez, principalmente, ofrecían una asombrosa galería de retratos. Uno de ellos, el señor Huber, viejo profesor austríaco, pequeñito, semi calvo, por lo general en pantaloncitos de golf, nunca amable, haciendo juegos con los ojos siempre enojados detrás de pequeños lentes ovales de armazón dorado, íntimamente convencido de ser un desconocido genio del tablero, tenía la costumbre, cuando uno de nosotros, jóvenes jugadores, osaba lanzar un asalto intempestivo contra el blocao ultra cerrado de su enroque, de chillar con su acento germánico marcado y su histérica voz de falsete (lo que le causaba el regaño de toda la sala): Ach, la cheunesse franceze et catholik! Wunderbar, la pelle 
Denis Grozdanovitch

cheunesse innocente! Se encogía entonces sobre sí mismo unos instantes, luego -brincando literalmente de su silla- tomaba al vuelo un alfil que hacía saltar de su casilla de salida como un diablo de una caja, para hacerlo aterrizar estrepitosamente justo en medio de nuestro ataque que se veía con ello invariablemente desmantelado, y exclamaba (provocando nuevas protestas de la asamblea perturbada): que dites-fou de cela, cheune hóme? Ach! Ce n'est pas afec des ruses de poy-scouts que fous desarçonnerez le fieil Houbeur! Y se enfurruñaba de nuevo en su silla hasta la próxima alerta.

Rosenfeld, el judío gordo, dulce y soñador, de una amabilidad un tanto obsequiosa, con el sombrero eternamente apretado en la cabeza, cuando aceptaba jugar con nosotros -prefiriendo el resto del tiempo sentarse junto a las mesas donde ya había partidos iniciados para comentarlos con observaciones sardónicas- y si se daba el caso de que lo pusiéramos un poquito en dificultad, comenzaba a frotarse el mentón reflexionando largamente, gesticulando dolorosamente y luego murmurando lentamente: "Entonces, mi querido señor, usted me pone verdaderamente en aprietos... sí, sí, estoy muy confuso... ¿Cómo voy a salir de esta trampa?" -un silencio, luego de nuevo-:" iDios, que malo es conmigo! iAh! ya no sé cómo hacer... Es muy feo lo que me hace, inunca hubiera creído eso de usted, mi querido señor, me asombra!" Y se lamentaba así un largo rato, luego, resignado, con un amplio gesto de impotencia, suspiraba: "Bueno, en fin, tengo que hacer alguna jugada, no? Veo que usted se impacienta... isí, sí, lo veo! Y ya que es preciso que juegue, no encuentro por desgracia nada mejor para hacer que iesto!" Y muy despacito, sin levantar la pieza mal sujetada con una mano, empujaba hacia usted un peón aislado cuya posición había parecido hasta el momento completamente anodina, pero que se revelaría, cuatro o cinco minutos después, como la clave de un estrangulamiento irremediable que lo forzaba a usted al abandono, lo cual le hacía exclamar: "iAh! iPero entonces...! ¿Usted no lo había visto? Ah, tuve la suerte de encontarlo distraído hoy. iSí, sí, tuve mucha suerte! Créame que estoy desolado, querido señor. Acepte, juguemos otra partida; estoy seguro de que a ésa la ganará fácilmente. Usted es joven y mucho mejor que yo. Sí, sí, estoy seguro de ello." Y el 


\section{LOS CRONOCIDAS}

mismo guión se repetía de manera casi idéntica sin que pudiéramos ganarle jamás una sola partida a Rosenfeld -ique era muy fuerte!

Moullimard, gran zangolotino, algo dandy, siempre munido de su boquilla, que se sacaba elegantemente de la boca para burlarse mejor de nosotros, circulando entre las mesas sin dejar de bromear, estaba constantemente en busca de una posición estratégica desesperada. Una vez que la localizaba, usando sarcasmos apropiados obligaba casi al náufrago a cederle el lugar, y con algunos golpes que semejaban pases mágicos, recomponía la situación y sacaba ventaja -desinteresándose entonces de ella y prefiriendo abandonar la posición reconquistada al jugador inicial que, por otra parte, se afanaba casi en seguida en arruinarla metódicamente de nuevo, no habiendo entendido absolutamente nada de la manera en que Moullimard lo había sacado de apuros. Ahora bien, lo más extraño de este especialista en salvataje, único verdadero talento ajedrecístico entre nosotros, era que si se lo llegaba a obligar a termimar alguna de las partidas que había recuperado del desastre, se mostraba a su vez, ahora que ya no estaba acorralado, incapaz de conducirla a buen término, enredándose en combinaciones tan complicadas que terminaban por anularse a sí mismas y lo arrastraban a una derrota lamentable ante aquellos de los que tanto se había mofado anteriormente.

Un último, Tony -presumido pied noir, ${ }^{1}$ siempre de punta en blanco, jugando al gran señor, adulado por las secretarias que venían a tomar una copa al bar, emergía hacia las cinco de las carreras de Longchamp o de Auteuil, donde acababa por lo regular de "ocasionar una desgracia", exhibiendo fajos de billetes de banco que sacaba del bolsillo trasero de su pantalón para hacérnoslos oler, luciendo cada día un fular diferente (del tipo fantasía, que incita inmediatamente a la melancolía)- había puesto a punto una temible táctica en caso de derrota: fingiendo exasperarse y comenzando una disputa con uno de los espectadores que indefectiblemente estaba allí para recordarle el deber del juego limpio, volviendo además la cabeza para hacerlo, no seguía jugando sino que golpeaba con violencia las piezas sobre el tablero, como si se desinteresara de la partida, pero sin omitir sin embargo ponerlas, con una notable

${ }^{1}$ Francés de Argelia (T). 


\section{Denis Grozdanovitch}

habilidad, muy precisamente en la intersección de las casillas... -lo que le permitía, si no lo advertíamos en seguida, lanzar de una sola vez una combinación tanto más inesperada para él y sorprendente para nosotros, cuanto que la pieza clave provenía de una casilla donde no habría debido estar nunca... Si alguien le hacía notar sin embargo la cosa, se enfadaba tanto que se consideraba libre, herido en su honor de caballero (y más herido aún por estar, según él, mal entablada la partida), para abandonarnos con desdén en lo que él calificaba entonces de "jueguito lamentable".

Hoy rememoro, más bien con cierto asombro, esas horas infinitas, sustraídas del mundo ordinario, en que, con los ojos clavados en los casilleros blancos y negros de eso que se había convertido para nosotros en un verdadero universo paralelo, luchábamos paso a paso -desesperadamente, como si nuestras vidas dependiesen de ello- a fin de asegurar la supremacía estratégica, adquirida al precio de argumentaciones ábstractas insensatas y agotadoras, de los ejércitos -extrañamente inertes en sí mismos, aunque animados de fogosos movimientos dinámicos por nuestras imaginaciones obnubiladas-de esas tristes estatuillas de madera barnizada, ensuciada por miles de millones de caricias.

Existe en París una multitud de sitios donde persevera en su ser esta población, sin otra ambición que la de gozar día a día de los pequeños placeres que ha logrado reservarse, un poco al margen de la marcha del mundo: el muelle del Sena, hipódromos, salas de juegos clandestinos, academias de billar, clubes de ajedrez, de bridge, de tenis, de poesía, institutos de estudios abstrusos de todo tipo, trastiendas oscuras donde se cambian estampillas raras, viejos juguetes remendados, soldados de plomo pintarrajeados, medallas antiguas, pipas de todos los países, hachas prehistóricas, talismanes, fotos de ovnis, o qué se yo qué más... Hasta cápsulas de sodas que algunos coleccionan. Están también las citas de los fanáticos de la petanca, ${ }^{2}$ que se han vuelto tan consustanciales de los jardines y de los barrios de París como sus palomos, las guaridas de jugadores de 42 lo de yam que, durante jornadas enteras, nunca se cansan de experimentar la pequeña sacudida emocional provocada por la ilusión

${ }^{2}$ Especie de juego de bolos (T). 


\section{LOS CRONOCIDAS}

fugitiva de haber sido favorecidos por el destino mediante un feliz golpe de suerte... Y además, naturalmente, centenas, millares de cafés donde se estancan -en la media luz de los espejos corroídos y brumosos, en el suave bienestar del vermouth que se bebe despaciosamente en pequeñas copas, de los gauloises que se encadenan sin apagarlos, de los chistes idénticos eternamente repetidos y del espeso paño de las mesas donde se abaten las figuras familiares- los innumerables jugadores de baraja de las largas tardes parisinas...

En sus Nuits de Paris, Restif de la Bretonne lanza invectivas contra esta ralea de inactivos, aparentemente más numerosa en su época que en la nuestra y que él llama los "cronocidas". Describe largamente lo que considera como su decadencia y les prescribe el trabajo como fortificante, como antídoto para lo que cree que es su malvivir. Dicho esto, Restif, que tenía -subrayémoslo- bastantes razones para predicar la moral convencional a efectos de hacer olvidar su conducta libertina, no habría podido imaginar por cierto, en tiempos de la Revolución Francesa -a la que asistió como espectador y nos describió-que llegaría alguna vez una época semejante a la nuestra; una época en la que, como lo dice de manera excelente Julien Gracq (en alguna parte de sus Lettrines), hubiera tantos brazos y voluntades dispuestos al cambio y transformación del mundo, y tan pocas miradas para su simple contemplación, que se llegara por ello a decretar algo así como "la eminente dignidad de los perezosos". Por otra parte, ihubiera reaccionado Restif como lo hace, él, el flâneur de deux rives si alguna vez hubiera sabido lo que significaría un día la industrialización a ultranza, la estandardización y la uniformidad del trabajo, de las costumbres y de las conciencias? ¿Y quién pues habría podido en su época prever que esta famosa Revolución Francesa tendría por efecto ulterior el reforzamiento de los valores que había querido combatir? ¿Quién pues habría predicho la reaparición de los sufrimientos redentores caros a la cristiandad, bajo la forma del Trabajo elevado al rango de dogma intangible?; ique este mismo trabajo, acelerado y propagado, en absoluto disminuido por las máquinas, conocería tal expansión, tal velocidad incontrolada, que se tornaría estéril, hasta peligroso para la humanidad?; ique esta superproductividad desarrollaría una agitacióm basta tal punto privada de sentido, que una mayoría de 
Denis Grozdanovitch

hombres ya no haría, bajo pretexto de trabajar, más que sacrificar la mayor parte de las horas de su vida a un aburrimiento aniquilador y a cambio de bienes materiales cada vez más dudosos?; ¿que el consumo mismo de esos bienes materiales supermutiplicados se convertiría en una suerte de trabajo casi obligatorio?; ¿que, por último pues, la resistencia consciente o inconsciente a este engranaje comenzaría a ser casi heroica, ascética -que en el sentido en que Restif lo había entendido en su época, serían justamente, por el contrario, los trabajadores honestos quienes se transformarían en "cronocidas"... Sí, Restif -que gustaba de tomarse su tiempo para curiosear en los muelles del Sena a fin de descubrir cualquier novedad: libro, joven criada amable y no muy esquiva, viejo vituperador o bandas de "bribonzuelos" para reprender- ¿habría imaginado alguna vez que nosotros, parisinos de fines del siglo $\mathrm{XX}$, nos tornaríamos casi incapaces de experimentar todavía la simple, muy simple, sensación de existir -tontamente, con arrobo- a semejanza de los peces que, para mantenerse en la corriente, no tienen más que dar un "ligero y exacto coletazo compensador"?, ¿que los raros supervivientes que conservaran un resplandor de lucidez en esta alienación progresiva, terminarían ellos mismos - generosamente llevados por su afán de convencer-por entregarse, para predicarnos la despreocupación a metódicas y laboriosas argumentaciones?

No obstante, a fines del siglo pasado, Robert Louis Stevenson, sin duda uno de los seres más perspicaces que hayan existido, estaba humildemente tentado de hacer ver que los ociosos poseían algunos derechos, entre ellos el de ser tolerados y no molestados, perseguidos, incluso por aquellos cuya complexión misma y temperamento insoslayable los llevaba, de todos modos y a todas luces, a activarse y producir. Escuchemos lo que nos declara al comienzo de su Apologie des oisifs:

Hoy, que todo el mundo está obligado -bajo pena de una condena en rebeldía por crimen de lesa respetabilidad- a abrazar alguna profesión lucrativa, y trabajar en ella con algo que se parezca al entusiasmo, una denuncia de la parte contraria -la que se satisface con lo que tiene, y reivindica el mantenerse como espectadorasabe un poco a bravata, si no a fanfarronada. No debería ser así, 


\section{LOS CRONOCIDAS}

sin embargo. El ocio -como se lo llama- que no consiste en no hacer nada sino en hacer mucho de lo que no está reconocido en los formularios dogmáticos de la clase dirigente, tiene tanto derecho a declarar su posición como la misma industria. Es preciso reconocer que la presencia de personas que rehúsan participar en la gran carrera de handicap por la ganancia de piezas de "sixpenny" es a la vez un insulto y un desencanto para los que se inscriben en ella. Un buen muchacho (como tantos que hemos visto) saca fuerzas de flaqueza, vota por los "sixpence" y, para recurrir al énfasis de un americanismo, "va a fondo". ¿Puede uno asombrarse de su resentimiento si, mientras él se desloma desesperadamente partiendo piedras en el camino, ve no lejos, en los prados, personas tendidas al fresco, con un pañuelo en las orejas y un vaso al alcance de la mano?

Stevenson observa con justa razón que los ociosos raramente están inactivos, que simplemente se consagran a actividades que las autoridades de turno consideran inútiles, incluso perjudiciales; condena a la que se expone por cierto a su vez la redacción de este texto, (he tenido mucho miedo de ello...) Oblomov -sin duda el perezoso más célebre de la literatura occidental, y en cuyo comportamiento se ha reconocido en parte la famosa intelligentsia de la época, al punto de consagrarle una nueva palabra de la lengua rusa: ioblomovtschina! Oblomov, es un inactivo declarado. Pero aquellos que trato de evocar aquí, no pueden ser convictos de oblomovismo, muy por el contrario. Sin embargo, ellos comparten con él una cualidad muy apreciable: tampoco se les puede reprochar que, en virtud de su incapacidad o su rechazo a participar de la histeria planificadora y activista de la sociedad contemporanéa, agreguen algún absurdo o confusión suplementaria (¿no es mucho ya?). Además, esta actitud, más instintiva que reflexiva, los lleva, más a menudo de lo que se podría esperar, a extremos casi heroicos: al no llegar a adaptarse a este imperativo categórico que quiere que placer y trabajo estén claramente disociados, prefieren casi siempre prescindir de lo necesario para consagrarse a lo superfluo. Por ventura, en forma paralela la sociedad actual -y principalmente por la evolución ultraespecia- 
Denis Grozdanovitch

lizada de la ciencia- ha comenzado a hacer cada vez más delgada, si no indiscernible en muchas ocasiones, la frontera que separa a los extravagantes que somos nosotros, de los individuos que ella puede legítimamente considerar dignos de respeto. Parece incluso que no puede ya arriesgarse mucho a intentar una discriminación entre ellos. Me han referido, en efecto, que las autoridades de la CNRS tuvieron muy recientemente la veleidad de sancionar a uno de los investigadores que estaban bajo su dependencia -el cual estaba, excepto en lo que concernía a sus emolumentos, casi "espectralizado". Ahora bien -pese al hecho de que el mismo interesado no consideraba a la sanción totalmente inicua en la medida en que, como lo reconocía sin rodeos, estaba perfectamente consciente de haber tirado demasiado de la cuerda- todos sus colegas investigadores se coaligaron en un gran impulso generoso para obtener su rehabilitación en el seno del organismo, logrando de paso hacer admitir este precepto deontológico que sin dudas sentará en adelante jurisprudencia ante las instancias superiores: "que un investigador está obligado a buscar, ino a encontrar!" Se aprecia en qué medida este acontecimiento, que anuncia quizá el comienzo de un alivio en lo que nos concierne y -iquién sabe?- a lo mejor hasta un reconocimiento oficial de nuestras ocupaciones, puede parecernos tranquilizador. Permítaseme evocar algunos recuerdos a este respecto.

En la época en que yo era un joven jugador de tenis, pasablemente dotado, y fui requerido por la federación para participar con algunos camaradas en un entrenamiento semanal en un gran club parisino, más o menos oficialmente, un experto en balística, miope como un topo, el bravo señor Pelletier, venía a explicarnos en el pizarrón, con esquemas de apoyo, la probable trayectoria de las pelotas y su previsible rebote según los efectos y la potencia del golpe que le imprimiéramos. Este sabio, que no había tocado una raqueta en su vida, se mostraba estupefacto cuando le probábamos con la práctica que una pelota podía muy bien tomar una trayectoria o poner de manifiesto un rebote que su teoría había decretado imposibles. Pero como no era terco -era ante todo un investigador en estado puro- una vez pasada la sorpresa, se inclinaba ante los hechos con un candor maravillado -a veces hasta con entusiasmo- y regresaba a sus cálculos a fin de elucidar el curioso fenómeno. 


\section{LOS CRONOCIDAS}

Más tarde, cuando viajaba regularmente al principado de Mónaco, me alojaba en un minúsculo hotel oculto en un callejón estrecho y oscuro, donde vegetaban los últimos artesanos y pequeños comercios que databan de la época de Marcel Pagnol. Allí encontraba yo ineluctablemente a dos profesores de matemáticas jubilados, Marechal y Couturier, cuyos magros subsidios les permitían conservar un cuarto a cada uno en el desván y comer en el hotel que hacia las veces de casa de huéspedes. Esos viejos señores con trayectorias muy respetables, aunque de ordinario un poco descuidados en sus trajes gastados que databan de épocas antediluvianas, pasaban todo el tiempo en conversaciones matemáticas increiblemente abstrusas y complejas, cuchicheando y dibujando sobre los manteles de papel esquemas herméticos que recortaban enseguida cuidadosamente para ocultarlos en su viejo portafolios de cuero, lanzando miradas inquietas y recelosas hacia los vanos de las puertas... Un agente secreto los hubiera tomado sin duda por nostálgicos anarquistas de retaguardia que se afanaban por fabricar una última bomba vengadora. Ahora bien, si de bomba se hubiera tratado, no podría ser otra que la que explotaría en la primera plana de los periódicos sensacionalistas al día siguiente de la gran noche en que ellos hicieran por fin saltar la banca del casino con ayuda de una de las martingalas milagrosas que perfeccionaban incansablemente en secreto desde hacía años, y cuya exactitud iban a verificar cada noche en la ruleta -siempre a un tris de resultar, nunca completamente a punto, iay!-vistiendo para hacerlo dos magníficos esmoquines comprados a plazos y que parecían cuidar como a la niña de sus ojos. Esas interminables discusiones los hacían entretenerse a veces en la comida más allá de la hora establecida; se les presentaba entonces su respectiva nota, que ellos tenían la costumbre de calcular por separado cada día para agregarle o restarle las sumas que parecían tener en litigio, abismándose entonces ambos en series de operaciones inverosímiles, enredándose y no llegando nunca a ponerse de acuerdo, hasta que Angelo, el amable y agudo jefe de comedor, que los conocía bien, viniera en su ayuda e hiciera el cálculo mentalmente. Los vi así durante muchos años, antes de saber que uno de ellos, Marechal, había sucumbido a una crisis cardíaca en el hotel algunas horas después de haber ganado al fin una suma bastante importante en la 
Denis Grozdanovitch

ruleta, pero de una manera totalmente fortuita en la medida en que Couturier, que normalmente era el jugador del equipo y cuya vista comenzaba a disminuir, habiendo leído mal en el cartoncito que consultaba a escondidas las cifras de su combinación del momento, había jugado un número ligeramente diferente del previsto. Esta buena fortuna, fuera de toda previsión y tan ajena a los laboriosos esfuerzos de los años precedentes, había fulminado a Marechal y tornado inconsolable a Couturier, quien, según Angelo, había retornado a Tourcoing, de donde era originario, a terminar melancólicamente sus días, y había donado la suma tan indebidamente ganada a las obras de Nuestra Señora de Mónaco...

Mi abuelo, también jugador empedernido aunque no del todo científico y que perdió en una sola noche la pequeña fortuna que había amasado en Londres entre las dos guerras, mantuvo luego durante muchos años a un sabio austríaco que vivía en una de las piezas del fondo del departamento, donde había instalado -según mi madre y sus hermanas, admitidas a veces a contemplar el conjunto fascinante- una red muy complicada de pequeñas montañas rusas hechas con módulos de ensamblaje tipo meccano, sobre cuyas pendientes circulaba una bola de plomo cromado que, una vez soltada desde la cima más alta del circuito, regresaba casi a su punto de partida (a diez o quince centímetros de éste) sin llegar nunca a cerrar íntegramente el circuito. Este eminente sabio-que terminó por desaparecer un buen día, no sin antes haber iniciado, tal como lo presentíamos, a mi abuela en los gozos y misterios de la física compensatoria en un estilo, así lo espero por ella, menos mecánico que el de sus experiencias habituales- buscaba el movimiento perpetuo...

El gran matemático Koenig había calculado que la celdilla ideal no era exactamente la que las abejas edificaban inocentemente en su colmena; propuso entonces un modelo ligeramente mejorado que interesó incluso a algunos apicultores, sin lograr - hay que decirlo- que lo adoptaran, hasta que otro gran sabio, Cramer, se dio cuenta de que Koenig se había equivocado y que las dimensiones de la celdilla primordial -la que las abejas utilizaban desde siempre y que un tercer sabio, Maraldi, había vuelto a medir muy cuidadosamente entre tanto- eran con mucho las más perfectas posibles. iTodo volvía a estar en orden!

Pero el más ejemplar entre todos los que tuve ocasión de encontrar 


\section{LOS CRONOCIDAS}

seguirá siendo, sin ninguna duda, Samuel Benguigui. Éste habitaba en Pau, en el último piso de una moderna torre construida en el borde de un acantilado que dominaba desde una centena de metros el valle del Garona. A la edad de setenta años, retirado de la función pública, Benguigui se había vuelto muy versado en aerodinámica espacial, y pasaba largos ratos haciendo sesudos cálculos, luego dibujando los planos del avión que, hasta donde recuerdo, eran en sí mismos muy estéticos. Concluida cierta fase preparatoria que podía tomar una o dos mañanas, Benguigui pasaba a la construcción propiamente dicha del artefacto, cuya insigne particularidad consistía en estar confeccionado exclusivamente en papel (por lo general con viejos números del Sud-Ouest), estando prohibido incluso el cartón. Terminada la fabricación, Benguigui, que era muy metódico, comenzaba por tomar una foto del prototipo, y luego, si el tiempo se prestaba para ello, pasaba a la fase final y solemne, resultado de los esfuerzos de los días precedentes, iel lanzamiento! Cuando yo estaba presente, como ocurría a menudo en cierta época, Samuel iba a buscar una botella de espumoso y brindábamos; luego, aproximándose con pasos contados hasta el borde del balcón que, como ya dije, dominaba una vasta extensión, lanzaba la nave de papel al espacio abierto con un gesto amplio y un poco enfático. Sentándose entonces en un sillón de mimbre reservado a tal efecto, envuelto en una manta y con un gorro encasquetado hasta las orejas, Benguigui supervisaba las evoluciones de su "avión", las que podían variar entre la caída instantánea y las dos o tres horas de elegante planear sobre el Garona y hacia las primeras estribaciones de los Pirineos que nos hacían frente en su altivo esplendor condescendiente -en un caso tan favorable, seguíamos las últimas evoluciones aguzando la visión con los prismáticos hasta que la endeble armazón desapareciera detrás de una cortina de árboles... Supe después que Samuel Benguigui no era único en su especie y que esta actividad, bastante extendida a través del mundo, se llamaba i"papidurología"!

En último término, me gustaría todavía señalar la creación bastante reciente de una asociación metropolitana de trivialistas, que reúne ya algunas centenas de adherentes en todo el país. Los miembros de esta institución muy respetable se encuentran a horas convenidas en cual- 


\section{Denis Grozdanovitch}

quier lugar -paradas de autobús, pies de columnas Morris, fondas de estaciones ferroviarias, etcétera- pero, y éste es el aspecto apasionante del asunto, sin tener ningún motivo preciso para encontrarse ni nada especial que decirse; siendo esta última condición, según lo que he podido comprender, totalmente deseable. Tampoco es obligatorio asistir efectivamente a la cita, aunque esta última cláusula sea uno de los únicos motivos de litigio en las raras discusiones que se generan a veces entre los trivialistas, cuando tienen oportunidad de encontrarse. De todas maneras, la condición de trivialista no implica ninguna regla definida; como lo declara con firmeza y entusiasmo su presidente y fundador: "Se es trivialista o no se es; iy se acabó!" El gran congreso, que reúne teóricamente a todos los miembros en el mismo lugar durante algunos días, es el punto culminante del año trivialístico. Los congresos de estos últimos años tuvieron grandes logros. Según una pareja de trivialistas que yo conozco, la principal actividad de los participantes consiste en ir a recibir a los que llegan a la estación lo más cordialmente posible y acompañarlos luego a su hotel profiriendo gran cantidad de interjecciones entusiastas a fin de salir al paso de toda veleidad de información sobre el orden del día, por temor de ciertos nuevos miembros todavía no compenetrados del espíritu institucional. En el congreso mismo, no está previsto naturalmente ningún tema en particular, y cada uno está requerido de intervenir exclusivamente cuando a él le plazca, y de preferencia cortando la palabra a aquellos cuyo discurso comience a apartarse peligrosamente de la más estricta trivialidad. Después, por lo general, luego de algunos días de discusiones desordenadas donde cada uno participa activamente de la algarabía general sin estar por tanto obligados a escuchar realmente a su interlocutor, los congresistas se separan dándose citas particulares para el año en curso -la mayor parte de las cuales no se cumple porque casi todos los trivialistas anotan las direcciones en pedazos de papel sueltos que rápidamente se extravían. Como lo declara también su presidente: "La asociación de los trivialistas no quiere distinguirse en nada de la vida en general, salvo, justamente, por la voluntad de sus miembros de tener una conciencia aguda de esto, y por su deseo de tranquilizarse mutuamente -y lo más posible- a este respecto!"

En realidad, esta población de excéntricos y de originales, de diletan- 


\section{LOS CRONOCIDAS}

tes, de "cronocidas" o de trivialistas -irreductible en sí misma- ha sobrevivido siempre un poco en todas partes, cualesquiera sean los regímenes, los acontecimientos y los trastornos -no lejos de la actualidad pero justo al lado, paralelamenre a ella, podría decirse; suave pero obstinadamente indiferente a lo que no tenía que ver con sus manías. Cuando yo era adolescente y mi padre me veía preocupado por no sé qué giro tomado por los acontecimientos, tenía la costumbre de repetirme: "Piensa, hijito, que en el curso de todas las circunstancias de la historia ha habido pescadores de caña." Ahora bien, Jünger cuenta en su Diario de Ocupación, que leí mucho más tarde, que entrando en París abandonado por el éxodo, encaramado sobre uno de los carros de su compañía, ve al pasar sobre el puente de la Concordia, más abajo de los pilares del mismo, a un tipo muy apacible que pesca fumando tranquilamente su pipa. Por otra parte, si entramos en no importa cuál museo de arte asiático antiguo y nos dirigimos hacia las colecciones chinas, encontraremos por cierto en algún momento, débilmente iluminado detrás de su vitrina, uno de los grandes rollos de pergamino exquisitamente pintado por alguno de esos misteriosos artistas Tch'an de los tiempos antiguos, y veremos en él, probablemente representados con sus uniformes rutilantes y multicolores, a los innumerables soldadotes temiblemente feroces de dos ejércitos rivales, enarbolando magníficas banderas pintarrajeadas sobre las que escupen fuego formidables dragones, despedazándose generosamente en combates sin cuartel. Al profundizar nuestro examen, acabaremos también por descubrir, en un rincón del rollo, por lo general disimulado detrás de una cortina de árboles, un pequeño estanque cubierto a medias por nenúfares donde viene a desembocar haciendo espuma alegremente un arroyo, que desciende de la montaña en graciosos zigzags y en cuya superficie, bajo un sauce vaporoso vecino de otros árboles coronados de frágiles flores blancas, no lejos de algunos patos meditabundos que se dejan derivar sobre la onda entre jirones de bruma, reposa una barca donde un pequeño personaje tocado con un sombrero de paja pesca sin preocuparse por nada. Y si tenemos todavía la paciencia de descifrar las notas eruditas que acompañan siempre a estas pinturas en los museos, nos enteramos de que, para los ermitaños de Tch'an, el pescador de caña (particularmente si está un poco ebrio de vino de arroz) representa el 
Denis Grozdanovitch

más perfecto símbolo de la sabiduría. Sobre uno de tales rollos, que se encuentra en el Museo Metropolitano de Nueva York, la minúscula sentencia caligrafiada en chino y que flanquea la cabeza del pescador ha sido traducida al inglés y dice así:

Right and Wrong reach not where men fish Glory and Disgrace dog the official riding his horse.

Lin Yu Tang, filósofo chino contemporáneo nos declara en su famoso libro La importancia de vivir:

Después de una larga exploración de la literatura y de la filosofía chinas, llego a la conclusión de que su más alto ideal ha sido siempre el hombre desapegado (Ta Kuan) de la vida y sabiamente desencantado. Esta sabiduría engendra una cierta grandeza de carácter, que da a cada uno la posibilidad de avanzar en la existencia con una ironía tolerante, de escapar a las tentaciones de la gloria, de la riqueza, de las proezas, y finalmente, de aceptar los acontecimientos. De este desprendimiento se derivan también el sentido de la libertad, el gusto por el vagabundeo, por el orgullo, por la indolencia. Pues sólo el sentido de la libertad y del ocio permiten alcanzar la alegría de vivir intensamente... El disfrute de una vida ociosa no cuesta caro. El verdadero gusto por el ocio se ha perdido en las clases ricas, y no se encuentra más que entre las gentes que tienen un supremo desprecio por el dinero. Proviene de una riqueza íntima del alma en un hombre que ama la vida simple y que se impacienta al tener que ganarla. Habrá siempre bastante vida para gozar de ella, para un hombre que está decidido a hacerlo.

Ahora bien, si desde el alma de los tiempos humanos, los chinos han reverenciado siempre una cierta forma de ocio, el mundo animal ofrece a nuestra admiración un ejemplo de diletantismo natural más antiguo y más perfecto aún. Parecería que el perezoso -bajo el aspecto con que podemos percibirlo en nuestros días en ciertas partes de la selva amazó- 


\section{LOS CRONOCIDAS}

nica-hubiera sobrevivido a todas las vicisitudes de la vida salvaje desde los tiempos históricos más remotos - constatación que invalida de manera decisiva la sacrosanta teoría darwiniana. ¿Cómo conciliar, en efecto, el credo del strugle for life con la fabulosa perennidad de un animal tan poco dotado para la competencia? Por otra parte, no es sin duda fortuito que sea precisamente un investigador americano, J. K. Summerville, quien haya consagrado cerca de 15 años de su vida a acechar las raras evoluciones de este despreocupado refractario en su medio natural. Para hacerlo, y como se puso de moda desde Konrad Lorenz que, en su tiempo, permaneció meses enteros sumergido hasta la cintura en un estanque cenagoso para integrarse mejor a un grupo de patos en el cual había puesto su mira, parece que Summerville trató de impregnarse totalmente de las costumbres de los perezosos -operación que rápidamente se revelaría mucho más acrobática y ascética de lo que hubiera pensado al comienzo, en la medida en que el animal permanece a veces colgado hasta 10 días seguidos de la misma rama, sin manifestar la menor veleidad por cambiar de posición (¿para dormir o para meditar?, esto sigue siendo incierto y las conclusiones de J. K. no son formales a este respecto), y no desciende de ella más que bajo el imperio de la extrema necesidad: el hambre y la defecación ("Durante el pequeño y el gran cometido, asegura J. K., él cierra los ojos con una expresión que nos atreveríamos a calificar de placer tranquilo.") Cuando el perezoso está en tierra, se toma todo su tiempo, desplazándose lentamente y cayendo frecuentemente en extrañas distracciones en cuyo transcurso, olvidándose visiblemente de su proyecto inicial, descansa cómodamente en la hierba, el vientre al sol, durmiendo o meditando de nuevo más o menos indefinidamente... En el agua, el perezoso se muestra todavía más a gusto: es el único animal de la creación que nada de espaldas; con su enorme estómago que le sirve de boya permitiéndole flotar, sólo tiene que usar sus brazos como pequeños remos para propulsarse indolentemente sobre las ondas... Por último -y tocamos con ello el aspecto sublime de las observaciones hechas en este animal- al considerar las fotos tomadas por Summerville, resulta que el perezoso, en el transcurso de todas las indolentes idas y venidas o meditaciones somnolientas que componen sus hábitos, no abandona nunca una sonrisa que no podemos 
Denis Grozdanovitch

describir de otra manera que como la expresión de una completa beatitud ("¿El perezoso sería un bienaventurado?", pregunta ansiosamente el investigador americano.)

Pero lo más sorprendente de lo que nos refiere Summerville siguen siendo las costumbres eróticas y sexuales del animal: si las aproximaciones amorosas se alargan penosamente, una vez apareados los compañeros se desenfrenan en una larga serie de espasmos frenéticos sin el menor pudor ni la menor inhibición; luego vuelven a caer -extenuados pero todavía arrebatados, en su semiletargo acostumbrado. (J. K. confiesa su perplejidad a este respecto: imanifiestan un verdadero entusiasmo o experimentan la acción de las leyes de la especie?)

De cualquier manera, el artículo donde pude recoger toda la información sobre las investigaciones de Summerville nos da a entender que, desde su regreso, el ilustre investigador tiene algunas dificultades para retornar al ritmo de la "vida activa". Parecería que J. K. no sale sino raramente de sí mismo, que sus editores se lamentan amargamente de la extrema lentịtud con la cual prosigue la redacción de su obra tan esperada, Comprender a los perezosos, y que su esposa tiene todas las dificultades del mundo para convencerlo de que tenga a bien descender de la viga maestra de la sala donde permanece agarrado jornadas enteras meditando...

Hay entre nosotros quienes pretenden ahora que entramos en la civilización del tiempo libre, que la energía desplegada hasta el presente en el mundo del trabajo será en adelante canalizada hacia un vasto universo de diversiones, que nosotros, los diletantes -dejando por ello mismo nuestro estatus de marginales, podríamos al fin, como lo desea Samuel Johnson, encontrar numerosos y nuevos compañeros de juego. Permítaseme ponerlo en duda. ¿No basta con observar el espíritu general que reina ya en las grandes realizaciones del turismo, de los clubes de vacaciones, del deporte y de la cultura de masas para comprobar que aquellos cuyo temperamento indefectible es producir y activarse no pueden, cuando se ponen de pronto a divertirse, dejar de introducir nuevamente en sus distracciones -inconscientemente al comienzo, deliberadamente después- los principios fundamentales quesiempre los han animado: eficacia, rentabilidad, profesionalismo, redención por el sufri- 
LOS CRONOCIDAS

miento? (¿Habéis tenido alguna vez la ocasión de contemplar esas nuevas gigantescas procesiones de flagelantes modernos que constituyen, a todas luces, los corredores de maratón o los corredores matinales que uno cruza en las calles, el rostro crispado por el esfuerzo, el ser orientado hacia la salvación de su alma?)

Ahora bien, querámoslo o no, esto no será nunca para nosotros, iepicúreos incurables! Incluso cuando nuestras actividades vinieran a confundirse en apariencia con las suyas, diferirían profundamente de ellas. En efecto, sería difícilmente concebible que lográramos nunca desembarazarnos de la calidad de aficionados desenvueltos que nos caracteriza. En pocas palabras, mientras nosotros continuaremos entreteniéndonos amablemente, ellos, como lo dice de manera excelente un humorista moderno, "trabajarán duro, los pobres, para divertirse".

Por lo demás, podríamos preguntarnos en qué medida la nueva sociedad del tiempo libre tolerará esta irreductible ineptitud de parte nuestra. ¿Nos permitirá dejar de lado sus competiciones y desdeñar su sed de marcas? ¿No buscará apartar, y luego confundir a los aficionados clandestinos? A continuación de lo cual, éstos serían suave y firmemente reubicados en el recto camino del tiempo bien administrado. iSe sabe con qué atenta solicitud la colectividad moderna trae nuevamente consigo a las ovejas descarriadas!

En una circunstancia tan siniestra, ¿qué alternativa se nos ofrecerá aún? ¿Deberemos profesar a escondidas, disimulados dentro de nuevas catacumbas? ¿Deberemos comunicarnos mediante mensajes cifrados y darnos a conocer? ¿Tendremos todavía el recurso de refugiarnos en esas comarcas (al menos por el lapso en que ellas mismas continúen existiendo) que, en todas las épocas, fueron la patria de los excéntricos: las islas británicas? ¿Conoceremos entonces una existencia semejante a la de aquel Jenkins, mencionado por Edith Sitwell en su libro Los excéntricos ingleses y que, "en esta fecha, en su año 157, se activaba siempre. Su biógrafo nos enseña en un arrebato de admiración", prosigue ella, "que este personaje pasó el último siglo de su vida pescando y que se lo veía a menudo nadar en las orillas, los pelos de su barba flotando como hierbas sobre las ondas del agua" $\mathrm{Al}$ menos, puedo afirmar que, muy reciente- 
Denis Grozdanovitch

mente y como esta última anécdota va a testimoniarlo, espero, la situación se presentaba tan favorable como en el pasado.

Mientras paseaba yo en un día ventoso, en pleno invierno inglés, por una calle del jardín público que domina el rebaño apretado de pequeñas casas de ladrillo rojo que conforman el barrio obrero de la ciudad de Sheffield, di, a la vuelta de un macizo que me lo había ocultado hasta entonces, con uno de los respetables súbditos de Su Majestad en pleno ejercicio. El individuo lucía un bello bigote bien recortado y estaba tocado con una gorra de tweed y cubierto con un abrigo acolchado que llevaba sobre saco y corbata. Con la pipa en la boca, sentado en una silla plegable en medio de un terreno cubierto de césped, tenía con una mano la bobina y con la otra el hilo que, en una larga curva graciosa, lo conectaba con un soberbio cometa rojo perdido en las alturas de un cielo tormentoso donde gruesas nubes cargaban a la carrera como elefantes furiosos. Como pasé delante suyo saludándolo con la cabeza, me interpeló:

- ¿Sería usted tan amable de tener esto unos instantes?

Respondí que estaría encantado y me pasó la bobina y el hilo, que tuve a fuerza de brazo, muy asombrado además de la potencia de tracción que se ejercía allí, mientras él, metiendo la mano en una especie de capacho como los que se usan para ir al mercado, sacó un termo de donde se sirvió, en un vaso metálico, un té muy caliente que mezcló con leche en un minúsculo envase de cartón sacado del bolsillo de su saco, y comenzó a beber tranquilamente en pequeños sorbos, vigilándome con el rabillo del ojo:

-iNo tan fuerte, joven, aflójelo un poco!

Luego, sacando un segundo vaso, todo abollado éste, de su capacho, me preguntó:

- ¿Un poco de té?

-Con gusto.

Una vez servido el té en el vaso que me destinaba, me lo tendió, luego volvió a agarrar la bobina y el hilo y yo bebí lentamente, parado a su lado, mientras el viento redoblaba esfuerzos como para arrancarle el hilo de las manos. Hubo un largo momento durante el cual él maniobró en 


\section{LOS CRONOCIDAS}

silencio, los ojos elevados al cielo, resistiendo con flema los asaltos venidos de lo alto. Luego, sin volver la cabeza, me dijo de repente:

-Qué tiempo maravilloso, ¿no?

Esperemos sin embargo que la evolución de las costumbres no llegue nunca a extremos tan incómodos como los evocados más arriba y que no tengamos que afrontar en el futuro, tal como estamos acostumbrados, nada más que la reprobación más o menos despreciativa de las gentes honestas que, además, cuando nos cuestionen con incredulidad, según su costumbre, a propósito de lo que consideran nuestras extrañas actividades, tengamos el ánimo de recordar lo que solía responder en similares ocasiones Ryokan, el monje loco:

...en la primavera con cien flores, en las grandes alamedas

yo juego a la pelota

si al pasar un transeúnte me pregunta le respondo:

"soy un hombre ocioso en una época de paz". 


\section{AMÉRICA: HISTORIA Y \\ CONMEMORACIÓN. UN COMENTARIO HISTORIOGRÁFICO}

Mauricio Tenorio*

It is not the literal past that rules us, save, possibly, in a biological sense. It is images of the past... A society requires antecedents. ${ }^{1}$

llega a la pequeña isla Guanahani, a la cual renombra San Salvador. Imagina que "Allí está el paraíso terrenal, hacia el golfo de las perlas, entre la boca de la sierpe y el dragón..." paraíso terrenal del Imago mundi encontrado en la parte más alta del mundo en forma de pera, "teta de mujer allí puesta". Sean las anteriores afirmaciones hechos históricos. 1992 irremediablemente completa el medio milenio de estos acontecimientos. Quinientos años es la medida temporal y espacial que nos separa del hecho.

* Universidad de Berkeley.

1 George Steiner, In Bluebard's Castle. Some Notes Towards the Redefinition of Culture. Yale University Press, 1971, p. 3. 
Mauricio Tenorio

Parece, pues, ser tiempo de conmemorar, que no forzosamente de celebrar. Ante el hecho, ¿qué puede decir la historia no como escrito de lo que sucedió, sino como oficio de escribir el pasado?

En distintos países se han organizado comisiones encargadas de la celebración del quinto centenario del "descubrimiento" de América o del "encuentro de dos mundos". Ciertamente no es puramente semántica la distinción entre "encuentro" y "descubrimiento", o entre "celebración" y "conmemoración". Cada término connota un entendimiento del pasado desde un presente interpretativo; entendimiento no exento de cuestiones nacionales, políticas, raciales e imperiales. Hablar de celebrar el descubrimiento de América rima con coloniaje, con el argumento de la ausente América en el concierto de la historia universal. La del medio siglo del descubrimiento de América parecería ser la fiesta de "gachupines" trasnochados, de tenderos ignorantes.

Asistir a la celebración del quinto centenario del "encuentro de dos mundos" parecería ir, al menos, más acorde con el "presente" interpretativo de que partimos; con el tiempo de los "post...ismos". Y sin embargo, lo de celebrar y de encuentro pone color de rosa, lo que nada nos hace pensar fue algo así como apretón de manos -léase destrucción ecológica, catástrofe demográfica, conquista de "cuerpos y almas". 2 La "leyenda negra" de España, heredada del indigenismo de De las Casas, y retomada y reformada por los historiadores norteamericanos de fines del siglo XIX -que siempre dejan sabor de un Nerón que acusa a Atila-, apoyó en América Latina el desarrollo de una conciencia antihispanista. Con

${ }^{2} \mathrm{Al}$ respecto han sido fundamentales los trabajos de historia demográfica de Borah y Cook (Cook, N.D. Demographic Collapse: Indian Penu, 1520-1620, Nueva York, 1982; Borah, W. et al. The Native Population of the Americas in 1492, Madison, 1976); los trabajos de historia ecológica de Crosby (The Columbian Exchange: Biological and Cultural Consequences of 1492, Wesport, $1967 \mathrm{y}$ Ecological Imperialism, New York, 1987); finalmente, los estudios de la "conquista de almas", como los de Todorov (El descubrimiento de América. La cuestión del otro, México, Siglo XXI, 1987), de Serge Grusinski (Le conquiste de lo imaginarie), y, para el caso de la América portuguesa, de Laura de Mello e Souza (O diabo e a Terra de Santa Cruz. Feitiçaria e Religiosidade Popular no Brasil Colonial, Companhia das Letras Sao Paulo, Brasil, 1987). 


\section{AMÉRICA: HISTORIA Y CONMEMORACIÓN}

algunas notables excepciones, la revolución de 1910, y su consecuente nacionalismo indigenista, reforzó este anti-hispanismo y lo hizo libro de texto $^{3}$ o mural. Y después de la tormenta del odio, cierto pensamiento latinoamericano optó por dar la impresión de calma y madurez hecha de olvido o de perdón: entonces: América y España a celebrar el fructífero encuéntro de dos culturas. Sin embargo, sin caer en condenas estériles, históricamente podría conmemorarse, que no celebrarse, el hecho histórico de América discutiendo al máximo lo que se sabe del hecho y sus consecuencias, y el porqué para algunos es encuentro, para otros descubrimiento. Un autoexamen acerca del cómo de la historia.

En esencia, los verbos descubir, encontrar o, el clásico del maestro O'Gorman, inventar, son verbos de la historia. No son Colón (América), Vasco de Gama (India, África) o Pedro Alvarez Cabral (Brasil) quienes descubren, inventan, describen o encuentran un territorio. Ellos se crearon la imagen muy suya de sus empresas. Son los intérpretes de esas evidencias, es decir, los narradores del pasado quienes consolidan cada uno de los nombres (descubrimiento, encuentro, etc.). Pasado siempre sujeîo a una interpretación ya iniciada con la distinción pasado-presente. Así, la discusión entre descubrir o encontrar (cuestión de interpretación del pasado; respuesta a las preguntas cómo y por qué del suceder) puede incluirse en la de celebrar, no celebrar o simplemente conmemorar, y cómo (cuestión de puro presente; referida a las preguntas sobre el significado que existe en armar las interpretaciones anteriores y los intereses detrás de cada interpretación).

En lo de conmemorar, la voz del profesional de la historia es fundamental, pero no definitiva: no es el amo y señor del presente en el que está contenido. El pasado es entendido por el historiador, distinguiéndolo del presente y suscribiendo una forma de conocimiento "verdadero" -lo cual está implícito en lo de descubrir, encontrar, inventar-. Forma

${ }^{3}$ Para una explicación del hispanismo y anti-hispanismo en la historiografía mexicana, véase González, Luis "75 años de investigación histórica en México" en México 75 años de Revolución. Educación, cultura y comunicación II, México, FCE, 1988; Florescano, E. Memoria Mexicana: Ensayo sobre la reconstrucción del pasado: época prehispánica-1821, México, 1987; y Matute, A. La teoría de la historia en México 1940-1973, México, SEP-Diana, 1981. 


\section{Mauricio Tenorio}

que, en tanto que se asume como verdadera, debe servir también para explicar su presente. El pasado y el presente insospechadamente se unen en los actos de conmemoración. Ahí pueden enfrentarse y desenmascararse distintas visiones historiográficas y diferentes intereses político-sociales. Son momentos óptimos para confrontar nuestras interpretaciones históricas generales, como una manera de ponderar nuestra conciencia del pasado; de ver, como propuso Isaiah Berlin, si es momento de derrumbar viejas, o de construir nuevas, explicaciones generales, de aquellas que hacen "experimentar un sentido de realidad y de dependenciabilidad (dependability)". 4

Toda la historia está sujeta a ser escrita y re-escrita por su tiempo. Para la mayoría de los que consideraríamos grandes momentos de la humanidad (por ejemplo, el uso del fuego, la elaboración de la rueda, etc.) no guardamos fecha ni nombres identificables. El así conocido "descubrimiento de América" quiere ser en la "conciencia histórica" de nuestros tiempos uno de los más emblemáticos de los "grandes momentos" de la historia, pero uno de los que no es anónimo. Toda historia se re-escribe, pero hace más ruido la reescritura de este gran momento no-anónimo. Y parece inevitable tener que conmemorar, que no forzosamente celebrar, el hecho de su "eventualidad" en un espacio-tiempo del que creemos estar ciertos. Porque esos grandes momentos no-anónimos además de

${ }^{4}$ Berlin sostiene que en algunas, raras, ocasiones la interpretación histórica "no sólo incluye, sino que además revela categorías básicas de importancia universal, en las cuales, una vez que son impuestas a la conciencia, reconocemos que subrayan toda nuestra experiencia; sin embargo, estas categorías están tan apretadamente entretejidas con todo lo que somos y sentimos, y por tanto tan totalmente dadas por hecho, que tan sólo tocarlas es transmitir un "shock" a todo el sistema; "shock" de reconocimiento y de los que puede trastornarnos, como es explicable que suceda cuando algo profundamente establecido y fundamental, que ha permanecido incuestionado y en la oscuridad, es súbitamente iluminado o sacado de su marco para ser inspeccionado de cerca. Cuando esto ocurre... llamamos a ese tipo de explicaciones, explicaciones profundas, fundamentales, revolucionarias, y decimos de aquellos que las proponen -Vico, Kant, Marx, Freud-que son hombres de sagacidad, de perspicacia y de genio." (Berlin, I. "The Concept of Scientific History" en Berlin, I. Concepts and Categories. Philosophical Essays by, Viking Press, New York, 1979, p. 132). 


\section{AMÉRICA: HISTORIA Y CONMEMORACIÓN}

forzar su conmemoración, poseen la característica de ser más que un área de la disciplina histórica: son conciencia histórica común de gentes y pueblos. La cuestión de "América", pues, trae a cuento contemporáneamente, y en alta voz, el problema de la historia y su quehacer.

Hay mitos sobre el quehacer de la historia que adquieren nueva vida en el debate sobre "América". Irineo Funes, el memorioso personaje del cuento de Jorge Luis Borges, ${ }^{5}$ poseía "más recuerdos que los que habrán tenido todos los hombres desde que el mundo es mundo". Sin embargo, nos dice Borges, era "incapaz de ideas generales". Este memorioso personaje cumpliría el ideal del omnisapiente cronólogo tan de la historiografía empiricista y positivista, partidaria de fechas y nombres a destajo. Funes es el "tipo-ideal" de la historia que se propone "verdadera" representación del pasado. Sin embargo, Funes, nos dice Borges, "no era capaz de pensar" pues "pensar es olvidar diferencias, es genealizar, abstraer". La historia es sin duda pensamiento, idea, comprensión, recreación y elaboración, pero la historia, dice Berlin, es "la proyección mental en el pasado de (la) actividad de selección y ajuste, de búsqueda de coherencia y unidad, junto con el intento de refinar esta actividad con toda la auto-conciencia de que somos capaces". 6 Nada nuevo hemos de agregar al añejo debate entre empiricismo e idealismo en historia, o entre asimilacionistas y autonomistas (la historia como disciplina científica a la manera de las ciencias naturales); ${ }^{7}$ librémonos de los extremos de decir que la historia es un simple subgénero de la acción, o una ciencia. Sin negar lo "duro" que resulta la evidencia histórica en sus distintas formas, lo cierto es que el recurrir a lo factual no nos daría la "verdadera" solución

${ }^{5}$ Borges, J.L. "Funes el memorioso" en Ficciones, Emecé, Buenos Aires, 1956. ${ }^{6}$ Berlin, Op. cit. p. 133.

${ }^{7}$ Véase al respecto Breisach, Ernst: Historiography. Ancient, Medieval, and Modern, University of Chicago Press, Chicago, 1983, p. 326-336. 


\section{Mauricio Tenorio}

que evitara los debates entre "descubrimiento" e "invención" y que nos diera los parámetros para justificar una celebración.

Funes el memorioso no es el único mito que recorre la interpretación histórica. Viajar al espacio-tiempo histórico de fines del siglo XV, es decir, vivir la historia parecería ser la única, contundente manera de decir cómo fue el pasado, y de, en concordancia, ordenar el rito de conmemoración. Dos peligrosos sueños rondan este ya de por sí onírico argumento: a) el de que la distancia que nos separa del hecho histórico "América" es nada más temporal y espacial; y b) que forzosamente para nosotros "viajeros" del futuro y conocedores de los capítulos siguientes de una trama sería más fácil entender y conocer el pasado, que es prólogo.

Y si el viaje al pasado fuera posible, también lo sería la transformación y ordenamiento del mismo. Sabríamos los porqués del ocurrir del pasado, y las vías alternativas que pudo haber tomado, conoceríamos lo que Trevor-Roper llama the unknown moments de la historia. Traigamos, empero, más cuento a la evidencia. Con una moderna cacería de dinosaurios, la imaginación de Ray Bradbury nos ilustra en sus límites esta visión del pasado como prólogo y de la historia como evolución. Así, un extraordinario safari al pasado "pre-histórico" (es decir, no narrado) se hace posible gracias a complicados mecanismos. El cazador experimenta la sensación de matar un terrible dinosaurio el cual, de cualquier forma -reza el cuento-, habría de morir milésimas de segundos después del disparo. La presa, se calcula, cae en la misma posición que en el pasado "verdadero" (el que pasó). Nada es alterado. Se camina sobre un pasillo electrónico, sin pisar ni tocar nada. Sin embargo, un descuidado cazador pisa el suelo pre-histórico y su hojarasca, sus insectos, y su composición química. El mal está hecho. Al regreso del safari, los cazadores encuentran todo cambiado, hasta la ortografía de las señalizaciones. El lector queda perplejo y exhausto de imaginar toda la hilación de cambios y transformaciones producidas por esa irresponsable pisada, pero queda también seguro de lo factible del juego de tiempos. Porque el pasado, se cree, es prólogo del presente. Empero, el pasado guarda una autonomía tan poderosa como nuestra incapacidad de entenderlo por la distancia temporal y conceptual que nos separa de él. Así, el pasado se vuelve, en efecto, prólogo, pero un prólogo: el del presente en que se cree o el 


\section{AMÉRICA: HISTORIA Y CONMEMORACIÓN}

que se defiende. La tarea es afirmar al máximo la base empírica de la historia. También es considerar la no-linealidad evolutiva de la historia, y desenmascarar los intereses del presente que construyen las ideas de pasado.

Aferrarse a los verbos descubrir, inventar, o encontrar en el entendimiento del fenómeno histórico llamado "América" es mantener una interpretación histórica particular. En esencia, cada interpretación no es hija legítima y pura de la verdad, sino, como afirma Louis Mink, de la "evidencia real, toda la cual por supuesto está en el presente". 8

Colón, por ejemplo, como fuera captado por el acierto de Luis Weckmann, ${ }^{9}$ constituye el último de los viajeros medievales, y no el primero de los modernos. Incluso es posible encontrar consenso en la historiografía contemporánea respecto del carácter "medieval" de la empresa española. Pero lo de medieval sólo es visible desde el punto de vista del tiempo, nuestro tiempo, post-iluminista.

Para la modernidad las divisiones entro lo "moderno" y lo medieval parecen muy claras. Bejamin Keen, ${ }^{10}$ tomando a lo autóctono de América (el pueblo azteca) muestra como existe una historia cambiante de lo que es generalmente aceptado como historia última. Sin duda antropológica, etnográfica e históricamente tenemos más datos del pueblo azteca, pero las interpretaciones no siguen paso a paso a las evidencias, sino que también se guían por el ambiente intelectual, las formas de ver la vida y los intereses de cada tiempo. Para Europa ha habido, así, varias nociones de América y lo "americano" que se entremezclan y siguen: han pasado de la América absorbida en el proyecto español de la magnae hispaniae, a la América utópica franciscana, a la América sutirdora de materias primas, a la América exótica, a la América rebeldey a la América refugio. O del indio esclavo por naturaleza (Sepúlveda), al paternalismo católico lascasiano, al utopismo franciscano inherente en el proyecto de la Iglesia Andina del nuevo milenio. ${ }^{11} \mathrm{Y}$ dentro del "canon" medieval

${ }^{8}$ Mink, L. "On the Writing and Rewriting of History" (1972), p. 89.

${ }^{9}$ Weckmann, L. La herencia medieval de México, El Colegio de México, 1984. ${ }_{11}^{10}$ Keen, B. The Aztec Image in Western Thought, New York, 1971.

11 A la manera como Gerónimo de Mendieta (1525-1604) lo pensó en su Historia eclesiástica (Cf. Phelan, J.L. El reino milenario de los franciscanos en el nuevo mundo, UNAM, México, 1972. 


\section{Mauricio Tenorio}

tuvieron espacio las visiones más renacentistas; la prueba: Pedro Mártir para quien los conceptos estéticos de los indios americanos ponían en evidencia lo relativo de las verdades absolutas europeas: "No me recuerdo de haber visto jamás cosa más fea, y a ellos les parece que no hay debajo de la luna nada más elegante: ejemplo que nos enseña de cuántas maneras el humano linaje se abisma en su vaguedad, y cuánto nos equivocamos todos..." 12

La re-visión de la historia no topa con pared. Los Aztecas, por continuar con el ejemplo, son considerados contemporáneamente una civilización "orgullo" de la humanidad (Soustelle), ${ }^{13}$ o una sociedad objetivamente (ya no moralmente) sanguinaria (Padden) ${ }_{2}^{14}$ o como un problema de la "distinción del otro". Todorov (1982), ${ }^{15}$ un lingüista, ubicó la cuestión de América dentro de una dimensión epistemológica. ${ }^{16}$ Para este autor, la presencia europea en el "Nuevo Mundo" significó semejanzas, mutuas incomprensiones, sumisiones, sincretismos y resistencias continuas. Pero, Todorov arguye, lo que nunca hubo fue "una configuración cultural y social que pudiera permitir comprender las diferencias". El prejuicio de la superioridad (someter al otro como esclavo) era tan explotador y subyugante como el de la igualdad (obligar al otro a ser yo). Lo de América es, pues, una cuestión de dominación de lo "otro". Ecos éstos, de una imparable tarea de revisión de la historia.

Es un problema historiográfico, por supuesto, que la "otredad", en tanto tal, siempre guarda poca evidencia histórica. La escritura de un pasado hegemónico se lleva a cabo unas veces encimando, otras borrando del todo "otros" posibles pasados. El pueblo azteca mismo re-escribió

${ }_{12}^{12}$ Martir, P. De orbe Novo (1530), Cf. Keen, B. Op. cit.

${ }^{13}$ Soustelle, J. La vie quotidiana dez aztéques a la veille de la conquete espagnole, París, 1955.

${ }^{14}$ Padden, R. C. The Hummingbird and the Hawk, Ohio State University Press, 1967.

15 Todorov, T. Op. cit.

${ }^{16}$ Que siguen las sendas trazadas por el estructuralismo y dos importantes trabajos de literatura e historia: Pepper, Stephen C. World Hypothesis: A Study in Evidence (Berkeley, 1966) y Auerbach, E. Mimesis: the Representation of Reality in Westem Literature (Princeton, 1968). 


\section{AMÉRICA: HISTORIA Y CONMEMORACIÓN}

y destruyó historia: en 1428 Itzcoatl ordenó se quemaran los códices y evidencias, y se re-escribiera la historia mexica de acuerdo al tiempo imperial que se vivía. Según parece, mitólogos como Tlacaelel llevaron a cabo la re-escritura de la historia, y consolidaron así el mito del sacrificio humano, del origen divino del pueblo Mexica y de su destino de dominación imperial. Algo similar hará después de la conquista Fray Juan de Zumárraga con los códices aztecas restantes. Quedó escasa evidencia de la presencia azteca; ${ }^{17}$ escasez que no niega su existencia, ni habla de su trascendencia, sólo dice de una cosa: su derrota.

Dudoso es que surjan nuevos importantes documentos sobre el tan debatido hecho "América". Como Funes el memorioso, sabemos, mejor aún, ignoramos lo que ignoramos. A las cartas y crónicas de Colón, a las epístolas de Cortés, a la historia de Fernández de Oviedo, F. de Gomara, Don Bernal Díaz del Castillo, etc... pocas fuentes primarias habrán de agregarse. No hay eslabón perdido cuyo descubrimiento nos permitiera afirmar la historia verdadera. Sin duda la labor de búsqueda es siempre bienvenida, pero en el terreno de los descubrimientos documentales y arqueológicos, el tema de Europa en Amérca guarda pocas sorpresas.

La tinta derramada en interpretar y reinterpretar el fenómeno de la América es irrescatable en una sola vida. Distintas épocas, distintos grupos, diferenes países han elaborado y dejado evidencia de sus visiones. ${ }^{18}$ ¿Qué evidencia debiéramos dejar? Aquí, pasado, presente y futuro se unen: pasado que explicamos representando, representación que enarbolamos y conmemoramos en el presente; conmemoración que es evidencia futura del pasado, hoy presente nuestro. De ahí lo importante de una consciente conmemoración. No hay mejor excusa para

${ }^{17}$ Véase, Portilla, L. M. El Reverso de la Conquista, Joaquín Mortiz, México, 1964; p. 15-19; Florescano, F. Op. cit.

${ }^{18}$ En la época contemporánea, con la generalización de la institucionalización disciplinaria de la historia, se hace más evidente la importancia de estar conscientes de lo necesario e inevitable de las reinterpretaciones. Como afirma $L$. Mink, es sólo en "nuestro siglo que los historiadores han llegado a verse a sí mismos como parte de una tradición de cambiantes interpretaciones históricas, de tal manera que la historiografía revisionista parece ser tan deseable e inevitable como la innovación tecnológica en la industria o la originalidad de estilo en el arte" (Mink, Op. cit., p. 91.) 
Mauricio Tenorio

acelerar (más allá de los academicismos) la revisión de la historia, para sustentar nuevas ideas, para destruir viejas conciencias. Sin embargo, conmemorar tiene bemoles.

\section{III}

Lejos de sugerir que sea estéril discutir lo "factual" de una interpretación u otra (vgr. descubrimiento, encuentro o Columbus jubilee), el énfasis en el hecho de la conmemoración subraya que tales discusiones son partes de un proceso continuo de re-escritura del pasado. El factor de lo factual, la "correspondencia" de las interpretaciones con la "real realidad", siempre será combustible del proceso, pero no su esencia. La imaginación, los intereses políticos, económicos y hasta estéticos del presente interpretativo juegan su parte.

No obstante las diferencias, el conmemorar nos vuelve a todos cómplices de un hecho, acaso sean las reminiscencias de una conciencia histórica que está siendo gradualmente cuestionada. No es que sepamos historia, luego conmemoramos; muy al contrario conmemoramos porque nos asumimos parte de una historia y nos urge hacer historia. La historiografía tradicional (europea o iberoamericana) "ejerció" como paradigma la noción de "descubrimiento". Aunque "descubrir" connotaba la degradación cultural y social de lo americano, las inteligencias americanas absorbieron el término como verdad. Juegos del conocimiento; no fue ni la primera ni la única vez: hoy, por ejemplo, hemos absorbido (cierto, también transformado) el originalmente imperial y napoléonico término de "América Latina" como modo de autodefinirnos. Hubo y hay matices en la noción de el descubrimiento de América, pero difícil es negar los visos molestamente "colonialistas", de anacrónica fe y confianza en el progreso, la modernidad de Occidente y su "espíritu" civilizador. Así pues, el pasado guarda su autonomía, y en Europa y en América la historiografía da muestras de transformación: ¿Quién descubrió América? La pregunta de perogrullo va cayendo en desuso. Ni la evidencia 
AMÉRICA: HISTORIA Y CONMEMORACIÓN

disponible, ni el devenir de nuestros tiempos nos permitirían llevar a cabo una responsable reconstrucción del pasado con base en estos viejos cimientos.

Conmemorar el Columbus jubilee, como en EEUU, acarrearía problemas para la gran mayoría del continente americano (por supuesto problemas no puramente factuales). Los debates en los Estados Unidos parecen ser menos acalorados. En 1978 el prolijo Latin-Americanists norteamericano Lewis Hanke se preguntaba "How Should the Five Hundreth Anniversary or the Discovery of America be Commemorated?", 19 y sin entrar en detalles sobre lo apropiado del término ("discovery"), Hanke consideraba que para íberos e iberoamericanos resultaba imposible evitar los "encuentros ritualísticos", tan de la aproximación casuístico-tomista de los hispanos. Uniéndose o resignándose a la conmemoración Hanke, más allá de las propuestas holliwoodescas que agotan las localidades de todo lo que tocan, propone una manera "americana" (toda América) de conmemoración. Hace del pasado lo que el pasado es para una sociedad moderna, profesionalizada y tecnologizada; es decir, una cuestión de expertos. Por ello, desde su punto de vista, en la fiesta del medio milenio los anfitriones deben ser los historians. Sobre todo, los profesionales de la historia no-hispanos quienes, a su buen ver, son quienes más han aportado al conocimiento de América y España. Ellos, parece sugerir Hanke, deben liderear una comisión internacional de expertos que llegara a la "completa comprensión de lo que pasó en América, Europa y otras partes del mundo como resultado de la apertura del Nuevo Mundo". 20

En el Columbus jubilee ni "Funes el memorioso", que no pensaba pero que sabía todo, podría sentirse a sus anchas. Lo complejo del proceso social, económico y cultural iniciado en el territorio conquistado por los países ibéricos, no es agotable en un happy anniversary. Empero, la

${ }^{19}$ Hanke, L. "How Should the Five Hundredth Anniversary of the Discovery of America be commemorated?" en Les Cultures Ibériques en Devenir, Essais publiés en hommage a la mémoire de Marcel Bataillon, fundación Singer-Polignac, 1978.

${ }^{20}$ Hanke, L. Op. cit. p. 426. 
Mauricio Tenorio

propuesta de Hanke rebasa ese simplismo, constituye un llamado a la profundización de los estudios. Nadie desacuerda con la propuesta; sin embargo, ésta adolece de varias inocencias: ¿lo que realmente pasó en el pasado puede ser "entendido en su verdadera importancia"?; ¿la conmemoración debiera ser histórica y de historia, o de historiadores y para historiadores?; ilo importante de la historia es la suma de trabajos históricos y el intercambio de opiniones? Habría que tener en cuenta la autonomía de los hechos históricos.

Imposible el "real" conocimiento de lo "real", pero igualmente imposible no seguir elaborando reconstrucciones llenas de evidencia real y de veracidad en nuestro presente. Tampoco se considera, en las propuestas del estilo de la de Hanke, que "América" como hecho histórico no puede quedarse en el cajón del historiador: forma parte de la conciencia histórica de mucha gente, de su sentirse y explicarse pasado en el presente y de sus proyecciones a futuro. Además, se trata de una real expresión de dominio, de conquista, que día a día aún se repite. La cuestión de América, en su medio milenio, aunque al cuidado del historiador seguramente debiera ser más que un "bacanal" de scholars. Es, repetimos, una nueva excusa para re-escribir la historia, y para volver al tipo de historia que toca al público en general, la que produce momentos de identidad o desidentidad, la que, debe procurarse, sea liberadora.

\section{IV}

Conmemorar, pero ninguna victoria ni simples "cumpleaños". Las cronologías omniabarcantes no son la explicación del pasado. Ni el imaginario viaje al pasado nos daría la "verdad" que nos permitiera condenar o premiar. ¿Podríamos convencer a Colón de que el río Orinoco no era la entrada a la tierra prometida? ¿Podríamos hacer que Cortés o su soldado Don Bernal captaran "el sentido de la diferencia" en los aztecas ante el espectáculo de un ensangrentado templo mayor? En el supuesto de tener el conocimiento real del devenir evolutivo de la historia, ¿po- 


\section{AMÉRICA: HISTORIA Y CONMEMORACIÓN}

dríamos seleccionar (a la manera de la economía: a contra-facto) evitar una muerte, una infamia, una traición o una injusticia que diera dirección "correcta a la historia"? No se puede más que cultivar el necesario aspecto empírico de la historia con el constante monitoreo de la historia de la historia, ver la parte constructiva de la historia. Porque en efecto, el buen análisis historiográfico -del cómo se escribe la historia- es por fuerza denuncia.

Conmemorar no es celebrar nada. Conmemorar es este discutir actual de términos, esta incansable re-visión y aceleramiento de los estudios del pasado. Es, ante todo, su difusión. Es estimular la emergencia de nuevas e innovadoras interpretaciones: nuevas posibilidades de desmistificación y de conciencias históricas liberadoras, más allá delproyecto de la magnae hispaniae o del indigenismo oficiales. Contrariamente a las leyes físicas, la historia no se desgasta por las fricciones, repeticiones y re-creaciones. Conmemorar es subir el pasado a la tarima de la atención pública. En una época que dice estar agotando las fronteras, hacer esto es afirmar en la academia, en el arte y en la calle la fertilidad de, diría Mink, la última e inagotable frontera: la historia; ésta es, a la vez, objeto de mistificación, y brazo y mano de la desmistificación. Lo que queda es cumplir con la historia al decir del grito popular mexicano: "iquémenle copal al santo manque l'húmen los bigotes!" 


\section{HABERMAS: \\ LEGITIMIDAD Y \\ DISCURSO \\ PRÁCTICO}

Enrique Serrano*

Para Habermas en la discusión en torno a la legitimidad está en juego la posible fundamentación de las cuestiones práctico-morales. Habermas reconoce que la definición empírica de la legitimidad es de gran utilidad en las investigaciones sociológicas. Sin embargo, él ve también que en esta definición hay una pérdida de la capacidad de argumentar racionalmente sobre los criterios de validez que intervienen en los procesos de legitimación. "La permuta empirista de la legitimación por aquello que se tiene por tal permite, pues, investigaciones sociológicas plenas de sentido... De todas maneras parece legítimo preguntarse por el precio que el empirista ha de pagar por la redefinición de su objeto. Cuando se entiende el ámbito objetual de modo tal que en su interior no puedan aparecer órdenes legítimos, sino tan sólo órdenes tenidos por tales, se ciega en el análisis el nexo existente entre las razones y los motivos; y en todo caso se excluye, por razón de método, una valoración de las razones independientes del actor. El estudiosos mismo se abstiene del enjuiciamiento sistemático de las razones en las que se apoyan las pretensiones de legitimidad." ${ }^{1}$

Cuando nos limitamos a dar una definición empírica de la legitimidad adoptamos la postura de observadores, ocupados únicamente en cons-

\footnotetext{
${ }^{*}$ Universidad de Constanza, Alemania.

${ }^{1}$ Habermas, La reconstrucción del materialismo histórico (RMH), Taurus, Madrid, 1981, p. 266. Zur Rekonstruktion des historischen Materialismus (RHM), Suhrkamp, Frankfurt, 1976, p. 293.
} 


\section{Enrique Serrano}

tatar que la pretensión de legitimidad de un orden es reconocida de facto en un contexto social y tiempo determinado. Frente a esta postura Habermas destaca que el reconocimiento de la legitimidad está motivado, entre otras cosas, por apelar a razones y que la validez de estas razones sólo puede juzgarse si se abandona la posición de observador externo al proceso de legitimación. "Ahora bien: que las razones sean buenas razones es algo que sólo se pude establecer en la actitud perfomativa de quien participa en una argumentación, no en virtud de la observación neutral de aquello que éste o aquel participante en un discurso considera como buenas razones." 2

La intención de Habermas es desarrollar una "Teoría Crítica". Ésta no puede conformarse con una descripción de las diferentes formas de legitimaicón, sino que debe preguntar por un posible criterio normativo que nos permita juzgar las pretensiones de validez de aquéllas. Habermas retoma el reto de dar una definición normativa de la legitimidad. Lo interesante de este proyecto es que no pretende "reencantar" el mundo; por el contrario, asume tanto la crítica a las visiones tradicionales del mundo, como el reconocimiento de la pluralidad que caracteriza a las sociedades modernas. "Hasta ahora he analizado dos conceptos de legitimación: el empirista y el normativo. El primero es aplicable, hablando en lo que a las ciencias sociales antañe, mas resulta insatisfactorio por cuanto hace abstracción de una ponderación sistemática de los fundamentos de la validez. El otro concepto, que sería satisfactorio en este sentido, resulta empero, insostenible a causa del contexto metafísico en que se encuentra enmarcado. Por todo ello, lo que yo propongo es un tercer concepto de legitimación, que me atrevería a calificar de reconstructivo." ${ }^{3}$

Veamos esta definición de legitimidad, para después examinar en que consiste su carácter de "tercera" posibilidad. "Legitimidad significa que la pretensión que acompaña a un orden político de ser reconocido como correcto y justo no está desprovista de buenos argumentos; un orden legítimo merece el reconocimiento. Legitimidad significa el hecho del

\footnotetext{
${ }^{2}$ Habermas, RMH, p. 266. RHM, p. 294.

${ }^{3}$ Habermas, $R M H$, p. 270. RHM, p. 298.
} 
LEGITIMIDAD Y DISCURSO PRÁCTICO merecimiento de reconocimiento por parte de un orden político." Más adelante agrega Habermas: "Por legitimidad entiendo el hecho de que un orden político es merecedor de reconocimiento. La pretensión de legitimidad hace referencia a la garantía -en el plano de la integración social- de una identidad social determinada por vías normativas. Las legitimaciones sirven para hacer efectiva esa pretensión, esto es: para mostrar cómo y porqué las instituciones existentes (o las recomendadas) son adecuadas para emplear el poder político en forma tal que lleguen a realizarse los valores constituidos de la identidad social."4

La intuición inicial de Habermas es que la legitimidad de un poder está vinculada indisolublemente a un proceso de comunicación. El poder tiene, en tanto es un fenómeno social, una realidad simbólica; de ahí proviene su necesidad de justificación y también ahí se encuentran los medios de esta justificación.

El derecho natural ya había localizado la fuerza legitimante en la formación de un consenso racional. Pero la tradición del jusnaturalismo no se había conformado con mantener al consenso como sostén de la legitimidad, sino que, en casi todas sus versiones existe la tendencia a dar un contenido específico a ese consenso. En cambio Habermas busca llevar hasta sus últimas consecuencias la sustitución de las razones últimas, por las condiciones formales de un consenso racional. "Por niveles de justificación entiendo, pues, condiciones formales de la aceptabilidad de las razones que prestan a las legitimaciones eficacia, fuerza consensual y fuerza motivadora... Fuerza legitimante hoy sólo la poseen reglas y premisas comunicativas, que permiten distinguir un acuerdo o pacto obtenido entre personas libres e iguales frente a un consenso contingente o forzado." 5

Para Habermas el núcleo normativo de la legitimidad se encuentra en las condiciones pragmáticas que permiten la comunicación entre los individuos dentro del proceso de legitimación. La tesis fundamental consiste en afirmar que el lenguaje tiene como "telos" interno el entendimiento (Verständigung). A partir de esta tesis se proponen otras dos

\footnotetext{
${ }_{5}^{4}$ Habermas, $R M H$, p. 243 y $249 . R H M$, p. 271 y 276.

${ }^{5}$ Habermas, $R M H$, p. 251 y $254 . R H M$, p. 278 y 281.
} 


\section{Enrique Serrano}

complementarias: 1. En el concepto de entendimiento se encuentra implícito la idea de un acuerdo libre de coacción y 2. El concepto de entendimiento presupone una noción amplia de racionalidad. Con estas tesis se apunta la estrategia de fundamentación de una noción normativa de legitimidad que no tiene que recurrir a un orden trascendente (divino, natural o histórico). Ahora se plantea que son las condiciones que permiten acceder a un acuerdo racional las que poseen una fuerza legitimante y que estas condiciones se encuentran implícitas en todo proceso de comunicación lingüística. Por tanto, se trata de reconstruir los procesos de comunicación para determinar esas condiciones.

Habermas denomina a su concepto de legitimidad como "reconstructivo", ello hace referencia al método en que ese concepto se sustenta. El objetivo del llamado "método reconstructivo" es hacer explícitos los elementos y estructuras de saber preteórico, presentes en las acciones humanas. ${ }^{6}$ Examinemos algunos aspectos generales de este método para precisar el sentido del concepto "reconstructivo" de legitimidad.

Habermas se remite a los trabajos lingüísticos de Chomsky. Este último distingue entre "ejecución lingüística efectiva" (performance) y competencia lingüística (competence). Mientras la primera se refiere al uso del lenguaje en situaciones particulares, la segunda se refiere a los principios lingüísticos (fonéticos, sintácticos y semánticos) que debe asumir cualquier "hablante-oyente" en el uso del lenguaje. 7 Para Chomsky el objeto teórico de la lingüística no es el habla efectiva (performance), sino los principios a los que debe recurrir un hablante competente de una lengua (competence). La forma de acceder a estos principios que asume todo hablante competente es a través de una reconstrucción de los procesos lingüísticos, que tiene por objetivo distinguir los aspectos empíricos y contingentes de dichos principios, a los que Chomsky considera como "universales lingüísticos".

Por su parte Habermas sostiene que no sólo los rasgos fonéticos sintácticos y semánticos de las oraciones, sino también ciertos rasgos de

${ }^{6}$ Ver: Habermas, Zur Logik der Sozialwissenschaften, Suhrkamp, Frankfurt, 1982. McCarthey, La Teoria Crítica de Jürgen Habermas, Tecnos, Madrid, 1987.

${ }^{7}$ Chomsky, Aspectos de la teoria de la sintaxis, Aguilar, Madrid, 1970. 
LEGITIMIDAD Y DISCURSO PRÁCTICO las emisiones admiten una reconstrucción en términos universales. En otras palabras no sólo la lengua ("competencia lingüística"), también el habla ("competencia comunicativa") es susceptible de una reconstrucción racional. ${ }^{8}$ en el acto del habla el hablante no sólo emite una oración con un contenido empírico ("O"), también la situa pragmáticamente a través de un "modo" (fuerza ilocucionaria), por ejemplo, "te prometo que o", "te exigo o", "te aseguro que o", etc. La encargada de reconstruir las estructuras generales que aparecen en todo acto del habla es la "pragmática universal".

"He propuesto el nombre de pragmática universal para el programa de investigación dirigido a la reconstrucción de las bases universales de validez de habla... La intención básica de la pragmática universal de los actos del habla se expresa en el hecho de que tematiza las unidades elementales del habla (emisiones) en la misma actitud que la lingüística tematiza las unidades del lenguaje (oraciones). La meta del análisis reconstructivo del lenguaje es la descripción explícita de las reglas que un hablante competente debe dominar para formar oraciones gramaticales y emitirlas de forma aceptable. La teoría de los actos del habla comparte esta tarea con la lingüística. Mientras que esta útlima parte del supuesto de que todo hablante adulto posee un conocimiento implícito reconstruible, en el cual se expresa su competencia en reglas lingüísticas (para producir oraciones); la teoría de los actos del habla postula una competencia de reglas comunciativas correspondientes, a saber, la competencia de usar oraciones en actos del habla. Se supone además que la competencia comunicativa tiene un núcleo tan universal como la competencia lingüística. Una teoría general de las acciones de habla describiría, por tanto, exactamente aquel sistema fundamental de reglas que dominan los sujetos adultos en tanto que pueden satisfacer las condiciones de un empleo afortunado de oraciones en emisiones, con

\footnotetext{
${ }^{8}$ Esto es a lo que se ha denominado el "giro pragmático" que tiene sus bases en las teorías de Wittgenstein, Austin y Searle. Wittgenstein, Philosophische Untersuchungen, Suhrkamp, Frankfurt, 1984. Austin, Cómo hacer cosas con palabras, Paidós, Barcelona, 1982. Searle, Actos de habla, Cátedra, Madrid, 1980.
} 


\section{Enrique Serrano}

independencia del lenguaje particular al que esas oraciones pertenezcan y de los contextos contingentes en los que se insertan los enunciados."

El objetivo de la pragmática universal es identificar y reconstruir las condiciones unviersales de un posible entendimiento entre los sujetos sociales. Habermas sostiene que estas condiciones contienen un núcleo normativo. Toda comunicación se encuentra ligada (implícita o explícitamente) a "pretensiones de validez", estas son las siguientes: 1. Entendimiento (el cual exige que las emisiones del hablante sean inteligibles); 2. Verdad (la cual exige que los contenidos proposicionales o presuposiciones existenciales sean verdaderas); 3 . Veracidad (la cual exige que el hablante sea sincero o veraz) y 4 . Correción o Rectitud (la cual exige que la emisión sea correcta en términos morales). Estas pretensiones de validez nos remiten a las funciones pragmáticas del habla, las cuales, a su vez, nos permiten dar una clasificación de los actos del habla:

1) La primera de estas funciones es la "representativa", ella se refiere a la relación con un mundo objetivo "externo" (Verdad). Corresponde a los actos del habla "constativos".

2) La segunda es la "expresiva" y se refiere a la relación con el mundo subjetivo (Veracidad). Corresponde a los actos del habla "expresivos".

3) La función "interactiva" es la tercera y nos remite a la relación con otros individuos, es decir, con el mundo social (Corrección o Rectitud). A ella corresponden los actos del habla "regulativos".

Hasta ahora no hemos hablado del "entendimiento", ello se debe a que esta pretensión de validez es común a todos los actos del habla. Mientras que las otras pretensiones de validez relacionan la emisión del hablante con un orden extralingüístico (con el mundo externo, con el mundo subjetivo o con el mundo social), el entendimiento, en cambio, es una

${ }^{9}$ Habermas, "Was hei $\beta$ t Universalpragmatik?" (1976), Vorstudien un Ergänzungen zur Theorie des Kommunikativen Handelns, Suhrkamp, Frankfurt, 1984, p. 357 y $386-396$. 


\section{LEGITIMIDAD Y DISCURSO PRÁCTICO} pretensión inmanente al lenguaje en sus diversos usos. "La meta del entendimiento es acceder a un acuerdo que tiene como término una comunidad intersubjetiva de comprensión recíproca, de saber compartido, de confianza mutua y de coincidencia. El acuerdo se basa en el reconocimiento de las cuatro pretensiones de validez correspondientes: Entendimiento, Verdad, Veracidad y Rectitud. Podemos observar que la expresión alemana "Verständigung" (también la española "Entendimiento"- E.S.) es ambigua. Su sentido mínimo indica que dos sujetos entienden una epxresión lingüística de la misma manera. Su sentido máximo es que entre ambos existe un acuerdo relativo a la rectitud de un enunciado en relación a un contexto normativo mutuamente reconocido. Adicionalmente, dos participantes del proceso comunicativo pueden llegar a una comprensión sobre algo en el mundo y pueden hacerse mutuamente comprensibles sus intenciones. Si el pleno acuerdo, que engloba los cuatro componentes mencionados, fuera el estado normal de la comunicación lingüística, no sería necesario analizar el proceso de comprensión desde la perspectiva dinánica del producir un acuerdo." ${ }^{10}$

La acción comunicativa trascurre sobre el transfondo de un acuerdo problemático; los sujetos aceptan de manera ingenua o inmediata las pretensiones de validez inscritas en los actos del habla. Pero en cuanto una de estas pretensiones de validez se ve cuestionada la acción comunicativa queda bloqueada. Si los individuos desean mantenerse en el nivel comunicativo, deben entonces hacer explícitas estas pretensiones de válidez para restablecer el entendimiento, mediante la redefinición común de la situación. Es por ello que Habermas plantea el acuerdo, en tanto meta del entendimiento, desde una perspectiva dinámica. Cada una de las cuatro pretensiones de validez puede ser objeto de un desempeño (Einlösung) dentro de un contexto de interacción social en el que se busca justificarlas o fundamentarlas. En el caso de la verdad y la rectitud su fundamentación puede requerir salir del contexto de la acción y pasar a una situación discursiva. En el "discurso" se busca apoyar estas pretensiones de validez con argumentos. ${ }^{11}$

${ }^{10}$ Habermas, "Was hei $\beta$ t Universalpragmatik?", p. 355.

11 Habermas, "Wahrheitstheorien" (1972), Vorstudien und Ergänzungen zur Theorie des kommunikativen Handelns. 


\section{Enrique Serrano}

El discurso representa una ruptura de la acción comunicativa para acceder a un plano en el que todos los participantes deben someterse a la dinámica de la argumentación, con la finalidad de llegar a un acuerdo sobre la validez de las pretensiones cuestionadas. El discurso es una continuación por otros medios (los argumentos) de la acción orientada al entendimiento. Mediante el discurso se prueba el carácter objetivo de la verdad de las emisiones y de la corrección de las normas. El resultado del discurso racional debe ser, según Habermas, un acuerdo válido no sólo para sus participantes, sino también para todo sujeto racional posible. "Llamamos, ciertamente, racional a una persona que en el ámbito de lo cognitivo-instrumental expresa opiniones fundadas y actúa con eficiencia; sólo que esa racionalidad permanece contingente si no va a su vez conectada a la capacidad de aprender de los desaciertos, de la refutación de hipótesis y del fracaso de las intervenciones en el mundo. El medio en que estas experiencias negativas pueden elaborarse productivamente es el discurso teórico, es decir, la forma de argumentación en que se convierten en tema las pretensiones de verdad que se han vuelto problemáticas. Llamamos racional a una persona que puede justificar sus acciones recurriendo a las ordenaciones normativas vigentes. Pero sobre todo llamamos racional a aquél que en un conflicto normativo actúa con lucidez, es decir, no dejándose llevar por sus pasiones ni entregándose a sus intereses inmediatos, sino esforzándose por juzgar imparcialmente la cuestión desde un punto de vista moral y por resolverla consensualmente. El medio en que puede examinarse hipotéticamente si una norma de acción, esté o no reconocida de hecho, puede justificarse imparcialmente, es el discurso práctico, es decir, la forma de argumentación en que se convierten en tema las pretensiones de rectitud normativa." 12

La descripción del discurso como un proceso de fundamentación racional de las pretensiones de validez, en donde sólo debe aceptarse la coacción del mejor argumento, es, evidentemente, una idealización. El

${ }^{12}$ Habermas, Teoría de la acción comunicativa (TAC), Taurus, Madrid, 1987, Tomo I, p. 38. Theorie des kommunikativen Handelns, (TKH), Suhrkamp, Frankfurt, 1981, B. I, p. 39. 
LEGITIMIDAD Y DISCURSO PRÁCTICO propio Habermas afirma que el discurso es una forma de comunicación infrecuente o rara, por tratarse de un proceso que ha de aproximarse suficientemente a condiciones ideales. En este punto se introduce el conocido y muy discutido concepto de una "situación ideal de habla". Con este concepto Habermas busca hacer explícitas las condiciones que deben satisfacerse para que se dé una argumentación plenamente racional. Entre estas condiciones se encuentra la de que los participantes de una comunidad de diálogo deben reconocerse recíprocamente como interlocutores con los mismos derechos. Cada uno debe tener el derecho de exponer sus argumentos y la obligación de escuchar los ajenos, así como la de respetar la lógica de la mejor argumentación. Habermas es consciente del carácter irreal de esta situación ideal de habla; sin embargo, él mantiene que no se trata simplemente de un ideal abstracto, sino que dicha situación ideal es una suposición que subyace a todo discurso. Cualquier individuo que entre en un discurso debe aceptar implícitamente la posibilidad de llegar a un acuerdo a través de la argumentación racional. Rechazar este supuesto sería desvirtuar el sentido del proceso de argumentación.

Por otra parte, Habermas afirma que esta situación ideal de habla también ha tenido una influencia en la vida política de nuestras sociedades. El principio de que la legitimidad racional se encuentra en el diálogo que busca un acuerdo es inseparable de la historia de la democracia. Como apunta Albrecht Wellmer: "De ahí que el principio de lo razonable para la ilustración, pueda interpretarse como una demanda de abolición de todas las relaciones de poder que no tuvieran más legitimidad que la de su facticidad. La razón no como un concepto opuesto al de autoridad, sino como un principio de comunicación pacífica y no forzada, frente a la realidad experimentada de una comunicación desfigurada de la política." ${ }^{13}$ El interés por estudiar la influencia del ideal de formación racional de la voluntad colectiva en la política está presente ya en los primeros trabajos de Habermas ${ }^{14}$ y es una línea de investigación que recorre toda su producción teórica.

${ }^{13}$ Wellmer, Teoría crítica de la sociedad y positivismo, Ariel, Barcelona, 1979, p. 51 .

${ }_{14}$ Habermas, Strukturwandel del Öffentlichkeit, Darmstadt un Neuwied, 1962. 


\section{Enrique Serrano}

Esta primera aproximación a la teoría de la acción comunicativa de Habermas nos permite precisar el sentido de su definición de legitimidad. Ahora podemos acudir al siguiente razonamiento: 1. La legitimación puede conceptualizarse como un proceso de comunicación. 2. El uso comunicativo del lenguaje tiene como objetivo interno la búsqueda del entendimiento. 3. Por tanto, la legitimidad estará dada por las condiciones que permiten un proceso comunicativo orientado hacia el entendimiento. 4. Como discurso práctico la legitimidad presupone la idea normativa de una argumentación libre de toda coacción externa, en la que se ponga a prueba la validez de los fundamentos del poder.

Lo que no debemos perder de vista es algo que el propio Habermas destaca, a saber: Entre el entendimiento en su sentido mínimo y el entendimiento en su sentido máximo existe un abismo. Dos sujetos entienden una expresión lingüística porque entre ellos hay una coincidencia respecto al significado (uso) de las palabras. Pero ello, como lo vio Wittgenstein, ${ }^{15}$ no implica una coincidencia de opiniones. Un fascista y un demócrata pueden entender cada uno el sentido lingüístico del discurso del otro, pero ello no implica que puedan compartir sus opiniones. La tesis de Habermas consiste en afirmar que el entendimiento lingüístico mínimo contiene un núcleo normativo, en el cual se exige del hablante-oyente que asuma la responsabilidad de buscar un entendimiento en su acepción máxima. Es decir, que fundamente racionalmente la pretensión de verdad y corrección inscrita en sus emisiones lingüísticas. El fascista y el demócrata tendrían, para cumplir con las exigencias de ese núcleo normativo, que someter sus respectivas visiones particulares del mundo a la coacción del mejor argumento. Es evidente que de esta manera se avanzaría un gran trecho en el camino del entendimiento. ${ }^{16}$

Theorie und Praxis, Suhrkamp, Frankfurt, 1978. Arbeit, Erkenntnis, Fortschritt (Afätze 19541970), Verlag de Munter Amsterdam, Amsterdam, 1970.

15 "Correcto y falso es lo que los hombre dicen; y los hombres concuerdan en el lenguaje. Esta no es una concordancia de opiniones, sino de formas de vida." Wittgenstein, Op. cit., fragm. 241.

16 Tendríamos que examinar con más cuidado qué significa la pretensión de corrección para las pretensiones normativas. Éste es un punto esencial para hablar de un entendimiento pleno. Pospongo esta tarea, ya que ella requiere de un examen más detallado de la teoría de la acción comunicativa. 


\section{LEGITIMIDAD Y DISCURSO PRÁCTICO}

Entre sujetos racionales puros (o casi) la meta del entendimiento sería, obviamente, más fácil de alcanzar. Habermas advierte que los individuos no se ajustan plenamente a esa racionalidad comunicativa, por tanto lo plantea como un horizonte normativo. He querido detenerme en ello para destacar el carácter normativo de la definición reconstructiva de la legitimidad. El problema reside ahora en precisar en qué sentido Habermas considera a su definición como una alternativa frente a las definiciones normativas de la legitimidad.

Creo que es posible aceptar que la definición de Habermas representa efectivamente una alternativa frente a las nociones tradicionales de la legitimidad. Su carácter alternativo se encuentra en la estrategia de fundamentación del nivel normativo. El método reconstructivo le permite a Habermas desechar el supuesto de un orden trascendente (divino, natural o histórico) como fundamento de las normas morales. De manera más precisa podemos decir que Habermas nos ofrece un criterio racional para juzgar críticamente la dimensión normativa inscrita en los procesos de legitimación. Este criterio es independiente de loś mitos, religiones, visiones del mundo, etc. que aparecen en los diversos procesos de legitimación tradicionales; ya que se trata de un principio normativo que hace referencia al carácter "formal" o estructural del discurso.

Habermas considera que la definición reconstructiva de la legitimidad también es una opción en el sentido de que no propone a priori un tipo específico de organización política. Debemos advertir aquí que la institucionalización de la idea de formación discursiva de la voluntad colectiva parece estar ligada necesariamente a una organización democrática del poder. Por ello alguien puede objetar que en la definición reconstructiva de la legitimidad sí hay una toma de partido a priori por un modelo específico de organización política. Sin embargo, Habermas mantiene que la democracia está definida esencialmente por un principio racional de legitimación y no por tipos específicos de organización. "La democratización no puede significar una preferencia apriorística por un determinado tipo de organización, en pro, por ejemplo, de la llamada 'democracia de identidad'... La discusión entre los representantes de una teoría normativa de la democracia por una parte y los de un concepto 'realista' o empírico de la misma por otra reviste unos caracteres igual- 
Enrique Serrano

mente difíciles. Si las democracias se diferencian de otros sistemas de dominación por un principio racional de legitimación, y no por tipos de organización caracterizados apriorísticamente, las críticas que entre sí se formulan unos y otros han de malograr su objetivo." ${ }^{17}$

El sentido de esta noción de la democracia lo podemos comprender mejor si tomamos en cuenta que es el resultado de una polémica con aquéllos que reducen la democracia a una serie de procedimientos. Habermas subraya que los procedimientos sólo adquieren una fuerza legitimadora en la medida en que se encuentran vinculados a una dimensión normativa. "Pero un procedimiento sólo puede legitimar indirectamente, es decir, remitiendo a instancias que por su parte tienen que ser reconocidas. Así, las constituciones burguesas escritas contienen un catálogo de derechos fundamentales, enérgicamente inmunizados contra los cambios, que posee fuerza legitimadora en la medida y sólo en la medida en que se lo entiende en conexión con una ideología aneja al sistema de dominación." ${ }^{18}$ En efecto, la implementación de procedimientos políticos hace referencia siempre a un sistema de normas que son consideradas como válidas. Pensemos, por ejemplo, en la regla de la mayoría que define los procesos electorales; sólo una descripción empírica estrecha puede hacer a un lado su relación con el valor de la "soberanía popular".

Ahora bien, así como los procedimientos democráticos nos remiten a un nivel normativo, los valores democráticos nos remiten a una serie de

17 Habermas, $R M H$, p. 252-253. RHM, p. 279-280. "Por consiguiente, la democracia, en tanto que principio de ordenación política, no particulariza a priori ningún tipo específico de organización (por ejemplo, un sistema de soviets) como el correcto. Ni tampoco excluye a priori ninguna organización que implique representacuón, delegación, etc. La cuestión es, más bien, encontrar en cada conjunto concreto de circunstancias mecanismos institucionales que justifiquen la presunción de que las decisiones políticas básicas contarían con el acuerdo de todos los afectados por ellas mismas si pudieran participar sin restricciones en una formación discursiva de la voluntad coleçtiva. Este principio sirve de estándar a la teoría crítica de la sociedad." MacCarthy, Op. cit., p. 384.

${ }^{18}$ Habermas, La lógica de las ciencias sociales, Tecnos, Madrid, 1988, p. 384. 
LEGITIMIDAD Y DISCURSO PRÁCTICO procedimientos. Podemos distinguir analíticamente entre el nivel de justificación de la dominación y los procedimientos de organización de la misma, pero entre ellos existe una mutua dependencia. A esto es muy importante tenerlo en cuenta, porque en la historia han existido regímenes que apelan a los valores democráticos, pero que no implementan los procedimientos democráticos de decisión. Ello ha conducido a dictaduras que se ejercen en nombre del "pueblo", de la "voluntad general", de la "clase universal", etc. La confusión en todas ellas consiste en querer conciliar los principios democráticos con la idea de "identidad". La única democracia viable es la que asume el carácter plural de nuestras sociedades.

Creo que se puede llegar a un acuerdo con la posición de Habermas al afirmar que la democracia no es un tipo de organización política a la manera de los modelos utópicos, empeñados en diseñar todos los aspectos de la organización social y dominados por el principio de la "identidad" o de la reconciliación plena de los conflictos sociales. La noción de democracia se encuentra ligada, sin embargo, a ciertos principios de organización política, los cuales permiten vincular su aspecto normativo con la realidad social. División de los poderes, procesos electorales competitivos, garantías institucionales a la libertad de opinión, organización, etc., son algunos de los rasgos esenciales de una organización democrática. Estos principios democráticos generales pueden encarnar en diferentes formas y ellos implican también una búsqueda continua de nuevos tipos de organización y mecanismos de participación política. Podríamos decir que la democracia presupone una organización social "abierta", esto es, en continua transformación, como consecuencia del ejercicio de la libertad.

Pero me parece apreciar que cuando Habermas califica a la definición reconstructiva de la legitimidad como una "tercera" posibilidad (frente a las definiciones empíricas y normativas tradicionales) no se refiere únicamente a los problemas metodológicos y organizativos, sino que su pretensión va más allá. Esto se puede ver cuando Habermas habla de la situación ideal de habla. "La anticipación de una situación ideal de habla tiene para toda comunicación posible el significado de una apariencia constitutiva que, a la vez, es manifestación de una forma de vida. Pero 
Enrique Serrano

no podemos saber a priori si esa ilusión, proviene, sin embargo, de suposiciones inevitables, o si pueden crearse prácticamente las condiciones empíricas para una realización (aunque sea aproximativa) de la forma de vida que esas suposiciones nos permiten poner de manifiesto. Desde este punto de vista las normas fundamentales del habla racional incluidas en la pragmática universal contienen una hipótesis práctica."19

La dificultad se localiza cuando la situación ideal de habla no se toma únicamente como una suposición contrafáctica (proveniente de suposiciones inevitables) que nos sirve como referente normativo en la crítica a los consensos fácticos, sino que se presenta como una situación en la que se anticipa una forma de vida que puede llegar a realizarse. Aquí se introduce implícitamente el supuesto de la posibilidad de acceder a una situación social donde las relaciones entre los individuos y lạ relación del individuo consigo mismo se tornen transparentes, lo cual permitiría un acuerdo pleno. Sobre este punto Wellmer observa: "Me parece que el concepto de comunicación libre de dominio, como Habermas lo construye, contiene el supuesto de que los problemas prácticos (morales-E.S.) tienen una unívoca solución racional -aún cuando nosostros podamos perderla o a causa de obstáculos internos o externos a la comunicación nos sea impedido acceder a la solución racional de los problemas. Habermas justifica este supuesto, en tanto él como medida de las soluciones concretas de los problemas prácticos no introduce un orden racional con carácter ontológico, sino el propio consenso libre de los individuos. Yo creo que en este pensamiento existe un círculo. ${ }^{20}$ En efecto, parece caerse en un círculo al pensar que el consenso racional nos permite encontrar una solución a nuestros problemas prácticos y, al mismo tiempo, creer que esa solución práctica es la posibilidad de acceder a un consenso racional.

El origen de este círculo vicioso se encuentra en la itnerpretación de la situación ideal de habla como la anticipación de una forma de vida. En la base de esta interpretación se encuentra el supuesto de una posible reconciliación (entre los hombres y entre la naturaleza "externa" e

19 Habermas, "Wahrheitstheorien", p. 181-182.

${ }^{20}$ Wellmer, A., Ethik un Dialog, Suhrkamp, Frankfurt, 1986, p. 198. 
LEGITIMIDAD Y DISCURSO PRÁCTICO "interna") en base a una solución racional unívoca de nuestros problemas prácticos-morales, a la que se accedería mediante un diálogo pacífico. En ello se percibe la sombra de la tradición utópica, en especial de la que va de $\operatorname{Marx}^{21}$ a Adorno. Esta herencia de la tradición utópica parece contradecir $\mathrm{o}$, por lo menos, entrar en conflicto con la noción "posmetafísica" ("posconvencional") de la razón que Habermas se propone desarrollar.

La tensión entre la noción de una razón "posmetafísica" y la tradición utópica no se encuentra en determinar hasta qué punto se puede realizar una organización racional de la sociedad, en la que la libertad de cada uno pueda coexistir con la de los demás. En esto ya advertía Kant lo siguiente: "Pues cuál pueda ser el grado máximo en que la humanidad haya de detenerse, y cuán amplia la distancia que necesariamente haya de quedar entre la idea y su realización, nadie puede ni debe determinarlo precisamente; porque es la libertad la que puede franquear cualquier límite indicado." 22 La dificultad entre la noción posmetafísica de la razón y la tradición utópica reside en el ideal utópico mismo, es decir, en plantear la realización de un sentido pleno, el cual otorgaría una solución racional unívoca a todos nuestros problemas en una situación de plena reconciliación. "Quien sueña con una supresión del poder hace referencia, implícitamente, a lo idéntico. ${ }^{23} \mathrm{El}$ ideal de la "identidad", que subyace a la tradición utópica, no puede compaginarse con una definición de la razón abierta a la pluralidad.

En este punto hay que tener cuidado. No se trata de afirmar simplemente que en Habermas se da un renacimiento de la filosofía de la historia y su ideal utópico de una reconciliación. Este autor es consciente de las dificultades que enfrentan las filosofías de la historia y toma frente a ellas una distancia crítica. De esta manera, él puede superar muchos de los errores de esas filosofías. Habermas no sostiene, por ejemplo, la

21 Zimmermann, Rolf, Utopie-Rationalität-Politik, Verlag Karl Albert, Feiburg/München, 1985.

${ }^{22}$ Kant, Kritik der reinen Vernunft, Suhrkamp, Frankfurt, 1974, Tomo I, p. 324 (a-317).

${ }^{23}$ Habermas, Rödel, U; Frankenberg, G; Dubiel, H. Die demokratische Frage, Suhrkamp, Frankfurt, 1989, p. 125. 
Enrique Serrano

existencia de un proceso causal regular en la historia. También reconoce que la posible "evolución" tiene costos y que con ellos aparecen nuevos problemas. "La dialéctica del progreso se manifiesta en el hecho de que, con la adquisición de capacidades para resolver problemas, se alcanza conciencia de la existencia de problemas nuevos... El sufrimiento a causa de las contingencias de un proceso que no podemos dominar gana una cualidad nueva en la medida en que nos atribuimos la facultad de intervenir en él de un modo racional. Desde el punto de vista negativo, este sufrimiento es el de una necesidad nueva. Podemos, así, hacer el intento de interpretar la evolución social en función de aquellos problemas y necesidades que se manifiestan a través de los adelantos evolutivos: el propio proceso evolutivo-social de aprendizaje genera nvevos recursos en cada etapa de desarrollo que, a su vez, suponen la existencia de dimensiones nuevas de la escasez y, con ello, necesidades históricas nuevas." 24

En la teoría de Habermas tampoco se acude a la idea de un "macrosujeto" al estilo de las filosofías de la historia tradicionales. Por el contrario, se habla de una dimensión intersubjetiva como base de la acción comunicativa, lo cual implica la pluralidad de sujetos. "La idea de un sujeto de la historia que se crea a sí mismo, era y es una ficción; pero en modo alguno es absurda la intención que esa idea a la vez expresa y yerra, de ligar la evolución de los sistemas socioculturales al tipo de control que es la autorreflexión en el sentido de una institucionalización políticamente eficaz de discursos (de comunidades intersubjetivas de orden superior autogeneradas por vía discursiva). ${ }^{25}$ De ahí la importancia de realizar un esfuerzo hermeneútico para comprender la intención de Habermas al proponer una teoría de la evolución social de los sistemas culturales.

Habermas mantiene, desde sus primeros trabajos, la necesidad de retomar la perspectiva de una "filosofía de la historia con intención práctica". Esto es, pensar a la historia no únicamente como una acumulación de sucesos, sino buscar en ellos un sentido que permita apoyar

${ }^{24}$ Habermas, RMH, p. 167.

${ }^{25}$ Habermas, La lógica..., p. 450. 


\section{LEGITIMIDAD Y DISCURSO PRÁCTICO}

nuestra práctica, como crítica del presente. ${ }^{26}$ El punto de partida de la teoría de la evolución social de Habermas es una "reconstrucción del materialismo histórico". "Reconstrucción" significa aquí una crítica interna al materialismo histórico, con la finalidad de acceder a un planteamiento más adecuado para los objetivos que esa misma teoría se había planteado.

Lo que se critica del marxismo es su concepción unilateral del desarrollo histórico de las sociedades. Para Habermas la evolución social no se puede reconstruir siguiendo únicamente la perspectiva de la organización de la fuerza de trabajo. Es por ello que Habermas se remite a los trabajos del joven Hegel para distinguir dos dimensiones de la dinámica social: "trabajo" e "interacción". 27 Por "trabajo" se entiende una acción que se guía por una racionalidad con arreglo a fines. Ésta puede adquirir el carácter de una "acción instrumental", cuando se orienta por reglas técnicas en relación a objetos del mundo externo, o el carácter de una "acción estratégica", cuando se orienta por ciertas reglas de preferencia imperantes en un contexto en relación con otros individuos. "Las acciones instrumentales de los distintos individuos muestran una racionalidad final, esto es: están coordinadas en relación con el fin productivo. Las reglas de la acción estratégica, según las cuales se produce la cooperación, son una parte componente necesaria del proceso de trabajo:"28

Mientras que por "interacción" se entiende una acción que se orienta

${ }^{26}$ Kant proponía una "paz perpetua" como horizonte normativo de la filosofía de la historia con intención práctica. Por su parte, Hegel trató de demostrar que esa reconciliación futura tiene una base objetiva en el propio debenir histórico. (Curiosamente Hegel vuelve a la perspectiva del Estado-nación como forma definitiva de esa reconciliación). Marx retoma la posición de Hegel y afirma que su mérito no es destacar la existencia de una lucha de clases, sino "mostrar" que esa lucha conduce "necesariamente" a una sociedad comunista. Entre la posición de Kant y la hegeliano-marxista se abre un abismo en el que se mueve continuamente Habermas.

27 Habermas, "Arbeit un Interaktiom", Bemerkungen zu Hegels Jenenser 'Philosophie des Geistes', Technik un Wissenschaft als 'Ideologie', Suhrkamp, Frankfurt, 1969. Ciencia y técnica como 'ideología', Tecnos, Madrid, 1984.

${ }^{28}$ Habermas, RMH, p. 133. 


\section{Enrique Serrano}

a través de normas intersubjetivamente vigentes, las que son reconocidas como tales y definen así expectativas recíprocas de comportamiento. "Ahora bien: los medios de vida no se producen con el fin de consumirlos. Al igual que el trabajo, también la distribución de los productos del trabajo está organizada socialmente. Las reglas de la distribución no se refieren a la elaboración de material o a la aplicación, adecuadamente coordinada, de los medios, sino a la vinculación sistemática de aspiraciones o intereses recíprocos. El reparto de productos acabados requiere, por tanto, unas reglas de interacción que se pueden desligar de las situaciones concretas y establecer con carácter duradero como normas reconocidas o como reglas de la acción comunicativa en el nivel de la comprensión lingüística." 29

En base a estas dos modalidades de la acción Habermas diferencia dos tipos de integración social:

1) La integración del sistema, que corresponde al trabajo. Por ella la sociedad se conserva dentro de ciertos límites, respondiendo a los problemas que le presenta su entorno mediante mecanismos impersonales (como lo es, por ejemplo, el mercado). En ella se busca un equilibrio social con independencia del consenso normativo de los individuos que intervienen en ella.

2) La integración social que corresponde a la interacción. En ella se crea un "marco institucional" sustentado en un consenso normativo de los individuos, originado en un proceso comunicativo. "La introducción de formas nuevas de integración social (por ejemplo, la sustitución del sistema de parentesco por el Estado) requiere un conocimiento de carácter práctico-moral, no un conocimiento técnico-valorativo que se pueda realizar en las reglas de la actuación instrumental y estratégica; esta sustitución no precisa de una extensión de nuestra capacidad de control sobre la naturaleza exterior, sino de un conocimiento que se materializa en las estructuras de interacción. En una palabra: una extensión de la

${ }^{29}$ Habermas, RMH, p. 133. 


\section{LEGITIMIDAD Y DISCURSO PRÁCTICO}

autonomía social frente a la naturaleza interior, que nos es propia. ${ }^{30}$

Estas dos dimensiones o niveles de la integración social están vinculadas en la dinámica social. La forma en que ellas se vinculan es a lo que Habermas denomina "principios de organización". En las llamadas sociedades tradicionales, por ejemplo, la integración del sistema se encuentra subordinada al "marco institucional" de la integración social. "Las 'sociedades tradicionales' sólo pueden subsistir mientras la evolución de los subsistemas de la acción con respecto a fines se mantiene dentro de los límites de la eficacia legitimadora de las tradiciones culturales. Ésta da lugar a una 'superioridad' del marco institucional, superioridad que ciertamente no excluye restructuraciones inducidas por un potencial excedente de las fuerzas productivas, pero que sí excluye la disolución crítica de la forma tradicional de legitimación. Esta inatacabilidad representa un buen criterio de demarcación de las sociedades tradicionales frente a las que han cruzado el umbral de la modernización.".31

En cambio el principio de organización de las sociedades capitalistas se caracteriza porque la integración del sistema (encarnada en el mercado y los sistemas administrativos) rompe con los límites del "marco institucional". El modo de producción capitalista permite una expansión permanente de los sistemas de acción con arreglo a fines. Esto es lo que percibían tanto Marx como Weber. "La superioridad de la forma de producción capitalista estriba en los dos casos siguientes: en la instauración de un mecanismo económico que garantiza a largo plazo la ampliación de los subsistemas de acción racional con arreglo a fines y en la creación de una legitimación económica bajo la que el sistema de dominación puede adaptarse a las nuevas exigencias de racionalidad que comparta el progreso de esos subsistemas. Es ese proceso de adaptación lo que Max Weber entiende como 'racionalización". 32

Habermas sostiene que en las sociedades capitalistas también hay una evolución en el nivel de la integración social. Su teoría de la evolución

\footnotetext{
${ }^{30}$ Habermas, RMH, p. 147.

${ }^{31}$ Habermas, Technik..., p. 67. Ciencia..., p. 73.

32 Habermas, Technik..., p. 70 . Ciencia..., p. 77.
} 


\section{Enrique Serrano}

social busca asumir la perspectiva de los dos niveles de integración, para ofrecer un diagnóstico sobre el desarrollo de las sociedades capitalistas. De esta manera, se busca, además, superar la unilateralidad presente en las teorías de Marx y de Weber. "La respuesta que propongo implica que el género humano en cuanto tal no aprende solamente en la dimensión del conocimiento técnicamente valorable-decisivo para la expansión de las fuerzas productivas-sino también en la dimensión de la conciencia práctico-moral -fundamental para las estructuras interactivas." ${ }^{33}$

Para conceptualizar el proceso de aprendizaje en el nivel práctico-moral Habermas acude, en un primer momento, al modelo del psicoanálisis y, posteriormente, al modelo de la psicología evolutiva de signo cognoscitivo (Piaget y Kohlberg). Ello resulta problemático, porque implica extrapolar los modelos psicológicos de socialización del individuo a la explicación del desarrollo de las estructuras normativas de la sociedad. En la base de esta extrapolación se encuentra la poco afortunada analogía entre ontogénesis y filogénesis, la cual ha sido uno de los temas favoritos de la filosofía y de la historia tradicionales. El propio Habermas advierte los peligros y dificultades que se esconden detrás de esta analogía; sin embargo, él insiste en usar estos modelos para dar cuenta de la racionalización cultural de las sociedades.

"Toda teoría general de la justificación permanece característicamente abstracta frente a las formas históricas de la dominación legítima. Aplicar raseros de justificación discursiva a sociedades tradicionales es comportarse de modo históricamente 'injusto'. ¿Hay una alternativa a esa injusticia histórica de las teorías generales por una parte, y a la arbitrariedad de la mera comprensión histórica por otra? El único programa con perspectivas que acierto a ver lo constituye una teoría que aclare estructuralmente la sucesión históricamente observable, de niveles de justificación y la reconstruya como un contexto lógico-evolutivo. La bien probada psicología evolutiva de signo congnoscitivo, que ha reconstruido, en lo relativo a la ontogénesis, las etapas de la conciencia moral, puede al menos entenderse como una indicación heurística y como un aliento." ${ }^{34}$

${ }^{33}$ Habermas, $R M H$, p. 149.

${ }^{34}$ Habermas, $R M H$, p. 171-172. ¿No es acaso una mayor injusticia reducir todas 
LEGITIMIDAD Y DISCURSO PRÁCTICO

Es curioso que Habermas haya retomado del jovel Hegel la distinción entre trabajo e interacción y no haya, al mismo tiempo, recuperado el principio de la "lucha por el reconocimiento" para dar cuenta del proceso de racionalización cultural. "Hegel atribuye el proceso de aprendizaje moral de la especie a la experiencia negativa de la lucha práctica, en la que los sujetos sostienen una lucha por su reconocimiento jurídico y social. Con ello Hegel anticipó una crítica materialista a las teorías del desarrollo cognoscitivas. De un concepto transformado de lucha social puede también beneficiarse una teoría social crítica, porque ese concepto abre la posibilidad para esa teoría de interpretar el proceso histórico como consecuencia de conflictos y enfrentamientos morales. ${ }^{.35}$ En efecto, para Hegel los conflictos sociales no se reducen a un problema de distribución de los bienes sociales, sino que implican una dimensión moral: la lucha por el derecho a tener derechos (el reconcomiento como persona). Desde este punto de vista la explicaicón de la racionalización de las estructuras normativas de la sociedad nos remite directamente a la historia de las luchas sociales y su influencia en el marco institucional y no a un proceso psicológico.

Es cierto que el concepto de "lucha por el reconocimiento" requiere, como sostiene Honneth, ser transformado para poder ser utilizado por una teoría crítica. Creo que una de las transformaciones más importantes de este concepto debe estar dirigida a romper el vínculo que existe en el sistema hegeliano entre esta lucha con una filosofía de la historia. La "lucha por el reconocimiento" no tiene un "origen", ni un "final", sino que la debemos entender como un principio abstracto que aparece en toda forma de asimetría social. En cada una de las formas de asimetría social "la lucha por el reconocimiento" adquiere un carácter específico. La manera en que se desenvuelve esta lucha en el nivel de la socialización de los individuos es, por ejemplo, diferente al modo en que se desarrolla

las modalidades de legitimación a eslabones en una cadena evolutiva? ¿No es una mayor injusticia desechar la especificidad de los diversos sistemas políticos a favor de una continuidad histórica?

${ }^{35}$ Honneth, A., "Moralische Entwicklung und sozialer Kampf". Zwischenbetrachtungen in Proze $\beta$ der Aufklärung, Suhrkamp, Frankfurt, 1989. Kritik der Macht, Suhrkamp, Frankfurt, 1989. 
Enrique Serrano

en la relación sociedad civil-Estado, etc. Recuperar el concepto de "lucha por el reconocimiento" puede servir además para establecer una mediación entre "trabajo" e "interacción" ("mundo de la vida"y "sistema"), así como para realizar una crítica radical a la noción funcionalista de poder (poder como "medio").

Los modelos evolutivos construidos a partir de la psicología nos ofrecen pautas de desarrollo poco flexibles, lo cual las hace inadecuadas para conceptualizar el desarrollo de las estructuras normativas de la sociedad. El "modelo Freud" nos presenta la emancipación del género humano en términos de autorreflexión y el "modelo Piaget" ${ }^{16}$ en términos de una lógica evolutiva que debe cumplir gradualmente con diferentes etapas de aprendizaje. En ambos casos se pierde la especificidad de la dimensión política y su apertura de posibilidades que no obedecen a una pauta prestablecida. Es cierto que Habermas no pasa por alto la presencia del conflicto social, pero con los modelos psicológicos parece subordinarlo a una lógica evolutiva situada por encima de él. ¿Se trata acaso de postular nuevamente la acción de una astuta razón que "usa" el conflicto como medio para cumplir sus fines? Por otra parte, la extrapolación de la psicología evolutiva nos acerca demasiado, a pesar de todas las precauciones que toma Habermas, a la idea de un sentido histórico que "debe" cumplirse.

Si queremos captar la especificidad del desarrollo de las estructuras normativas de la sociedad tendremos que volver al medio en el cual éstas se desenvuelven, a saber: el conflicto social. Mi propuesta es pensar el desarrollo de las estructuras normativas no como una "lógica evolutiva", sino a través de una vía negativa, esto es, como el cuestionamiento de las pseudouniversalidades o particularidades que pretenden adquirir un estatuto universal o que reprimen una perspectiva universalista. Precisamente la lucha por el reconocimiento podemos pensarla como un enfrentamiento las pseudouniversalidades. Esto nos acercaría al devenir histórico empírico, pues nos permitiría abordar el estudio de las luchas sociales no sólo desde la perspectiva de la redistribución de la riqueza, sino también en su sentido moral y jurídico. La lucha de individuos o

${ }^{36}$ Wellmer, "Über Vernunft, Emanzipation und Utopie", Op. cit. 
LEGITIMIDAD Y DISCURSO PRÁCTICO grupos que buscan su reconocimiento como "personas" y como tal cuestionan la pretendida universalidad de un orden establecido (reconocimiento que no sólo puede pensarse en términos formales). Pensemos en las luchas obreras, feministas, de minorías raciales, etnias, etc.

Es posible asumir los logros de las investigaciones psicológicas, sin tener que aceptar la conceptualización del desarrollo de las estructuras normativas de la sociedad como un proceso psicológico. Se puede relacionar la perspectiva ontogenética y la filogenética sin establecer entre ellas una analogía. Ello nos permitiría, además, recuperar los resultados de la ciencia antropológica (entendida como sociología de "otras" culturas). El logro más destacado de estas disciplinas es el reconocimiento de que los "otros", llamados "salvajes" o "pueblos primitivós", no son niños ingenuos, ni "buenos" (o "malos"), ni individuos que se encuentran en una etapa "prelógica", sino que representan simplemente otra forma de conceptualizar el mundo. Si acaso se puede hablar de una evolución de las estructuras normativas es, precisamente, en la capacidad de reconocer a los "otros", para aprender de ellos a percatarnos de nuestra propia unilateralidad. Es decir, aprender que la vida se puede racionalizar desde las más diversos puntos de vista. Esto no puede calificarse, desgraciadamente, ni como una enseñanza generalizada ni definitiva de nuestra cultura (en cualquiera que nos situemos).

En la Teoría de la acción comunicativa Habermas denomina este desarrollo como "decentración de las imágenes del mundo". "La evolución cognitiva significa en términos generales la decentración de una comprensión del mundo de cuño inicialmente egocentrista. ${ }^{37}$ Pero al utilizar los términos de la psicología evolutiva se presta a una confusión sobre el carácter de este desarrollo social.

No debemos perder de vista que la llamada "decentración de las imágenes del mundo" es el resultado de los conflictos sociales y que éstos sólo pueden objetivarse en un desarrollo histórico si se cumplen por lo menos estas dos condiciones: 1 . Un cierto equilibrio de poder entre las fuerzas sociales y 2. la transformación de ese equilibrio en una nueva forma de institucionalización de las relaciones de poder y por tanto en

${ }^{37}$ Habermas, TKH, Tomo I, p. 106. TAC, Tomo I, p. 103. 


\section{Enrique Serrano}

una nueva forma de ejercicio del poder. En este sentido me parece importante rescatar laintuición de Weber de estudiar el desarrollo de las imágenes del mundo en dos niveles: A) El de la relación entre las imágenes del mundo y las relaciones de poder y conflictos sociales. B) El de la lógica y dinámica de esas visiones del mundo. Hacer a un lado cualquiera de estos niveles es caer en la unilateralidad.

Es evidente que Habermas puede responder que la institucionalización de las nuevas relaciones de poder requiere de un nuevo nivel de las estructuras normativas de la sociedad. "Incluso quisiera sostener la tesis de que el desarrollo de estas estructuras normativas representa la avanzadilla de la evolución social, pues nuevos principios de organización social significan nuevas formas de integración social, y sólo éstas, por su parte, hacen posible la implementación de las fuerzas productivas existentes o la generación de otras nuevas, así como el incremento de la complejidad de la sociedad. ${ }^{138}$ Ante ello habría que preguntar: ¿Qué es primero, la transformación de las formas de ejercicio del poder o la transformación de las estructuras normativas? Me parece que si realmente se quiere superar la unilateralidad de la teoría marxista del desarrollo social hay que renunciar a las explicaciones causales simples.

Cuando afirmamos que se trata de explicar el desarrollo de las concepciones del mundo a través de una vía negativa, implica renunciar a la idea de una "evolución lógica" hacia una universalidad en la que se abren las puertas del entendimiento pleno (identificado con la "Verdad"). Se trata, como hemos dicho, de abordar el desarrollo social como un cuestionamiento permanente de las falsas universalidades. Esta crítica a las pseudouniversalidades se desencadena en el interior de los conflictos sociales, los cuales se desenvuelven tanto en la integración social como en la integración del sistema. Entre estos dos niveles existe una relación compleja (no olvidemos que se trata de una distinción analítica), irreductible a un vínculo causal simple. El proceso de desarrollo social no presupone necesariamente ningún punto culminante; ni tampoco la realización de un modelo de sociedad transparente. El desarrollo de las estructuras normativas no conduce a un entendimientó pleno o en su

${ }^{38}$ Habermas, RMH, p. 35. 
LEGITIMIDAD Y DISCURSO PRÁCTICO sentido máximo, sino a un entendimiento sobre la forma de enfrentar nuestros conflictos, que garantice tanto la integridad de la sociedad, como la integridad de cada uno de sus miembros.

Habermas en la Teoría de la acción comunicativa asume que la racionalidad comunicativa, entendida como el resultado de una comprensión decentrada del mundo, tiene un carácter procedimental y que, por tanto, de ella no es posible obtenerse el ideal de una forma de vida plenamente racional. $^{39}$ El propio Habermas califica al utopismo que confunde la ifnraestructura comunciativa con una forma de vida lograda como un error de la modernidad. Esto último nos permite llegar a un acuerdo fundamental, al permitir eliminar la ambigüedad del concepto de situación ideal del habla. Se tiene que aceptar que este concepto no presupone ninguna anticipación de una forma de vida ("lograda"), sino que sólo es un criterio normativo.

Por otra parte, esto también nos permite confirmar que la definición reconstructiva de la legitimidad no es una "tercera" alternativa, sino sólo un criterio para juzgar críticamente los consensos fácticos que sustentan las diversas formas de legitimación. La definición reconstructiva de la legitimidad tiene, entonces, que asumir la definición empírica de la legitimidad como punto de partida, sin presuponer una forma de legitimación "auténtica" o "verdadera" en que las relaciones de poder queden superadas. Su potencialidad crítica no se encuentra en anticipar una utopía de la reconciliación, sino en sustentar las críticas concretas a las diversas formas de legitimación. "Nosotros no podemos anticipar la perfección del sentido, sino sólo la eliminación del sinsentido. Nosostros no podemos pensar las relaciones entre los individuos completamente libres de toda coacción, ni una racionalidad plena, pero de hecho podemos intentar suprimir y a partar las coacciones y bloqueos que experimentamos." ${ }^{40}$

Con esta serie de observaciones críticas he querido llamar la atención sobre la tensión que existe en la teoría de Habermas entre la noción posmetafísica de la razón y la situación ideal del habla, entendida como

\footnotetext{
${ }^{39}$ Habermas, TKH, p. 110-113. TAC, p, 107-109.

${ }^{40}$ Wellmer, Op. cit., p. 220.
} 


\section{Enrique Serrano}

la anticipación de una forma de vida realizable. Habermas es consciente de esta tensión y de las dificultades que ella engendra. Creo que en la base de los cambios y modificaciones de su teoría se encuentra un intento de superar estas dificultades y no existe, hasta la fecha, una toma de posición definitiva ante este problema. No debemos olvidar que se trata de una filosofía viva. Con ello no me refiero únicamente al hecho de que Habermas esté vivo sino también a que se trata de una filosofía abierta, por principio, a la discusión y, por tanto, a la transformación.

Mientras tanto, por nuestra parte, podemos rescatar el principio de la "prohibición de las imágenes" (Bildverbot) que caracterizaba ala primera escuela de Frankfurt. Esta prohibición de imágenes se convertia en un rechazo de toda utopía positiva, lo cual dejaba como única alternativa la crítica a las formas de dominación concretas que se nos dan en el presente, así como la crítica a sus pretensiones de ser formas definitivas de la historia. ${ }^{41}$ Cuando la Teoría Crítica afirmaba "hay algo más", no se trataba de definir ese algo, sino destacar las contradicciones en las formas de organización del presente. No se trata de anunciar la realización del sentido pleno, sino denunciar y enfrentar el "sinsentido" en el presente.

41 Desgraciadamente la Escuela de Frankfurt no continuó con este proyecto. Como apunta George Friedman, la escuela de Frankfurt estaba lo suficientemente cerca de la tradición del judaísmo para retomar la esperanza de una redención, pero no lo suficiente para mantener esa esperanza dentro de la crítica al presente. Por ello se abandonaron a la idea de una reconciliación abstracta y a la desesperanza ante una realidad que se alejaba de ese ideal. "La Escuela de Frankfurt es, por último, más digna de alabanza por lo que no pudo realizar porque, en su fracaso, demostró la bancarrota de la modernidad." La filosofía política de la Escuela de Frankfurt, F.C.E., México, 1986. 


\section{LA UNIVERSIDAD: CONCIENCIA CRÍTICA}

Carlos de la Isla*

\section{D} os comentarios de introducción al tema: Cuando hablamos de la misión de la Universidad ide qué universidad hablamos? Con el término universidad ha pasado como con la palabra democracia: Las dictaduras más duras, las dictablandas más blandas junto con los pocos gobiernos más respetuosos del demos, todos los regímenes políticos justifican y se apropian de la elegante investidura de la democracia. De innumerables universidades de México y del Mundo se puede decir que en lo único en que coinciden es en el nombre. Sin embargo, a pesar de la desacralización de la Universidad y de sus tan diversas expresiones pienso que es legítimo hablar de algunas características esenciales, de algunas funciones obligadas de la Universidad con mayúsculas, aunque puedan existir instituciones que de Universidad sólo tengan el nombre.

El segundo comentario introductorio se refiere al que me parece el significado de la misión de la Universidad. Todos los enunciados que puedo pensar sobre la función de la Universidad con mayúscula suenan a utopía, a ideal imposible y soy consciente de que la finalidad de esta reflexión no es hablar de ideales de la razón pura a priori. Sin embargo, siento que es legítimo hablar de utopías sobre la Universidad o, como diría Hutchins, de la Universidad de Utopía; en primer lugar porque en nuestro presente histórico parece que las soluciones reales a los problemas de mayor tamaño todas parecen utópicas, lo que significa que a todo problema difícil corresponden soluciones difíciles.

* Departamento Académico de Estudios Generales, ITAM. 
Carlos De la Isla

Por otra parte, así como se decía hace dos mil años: las profecías tienen su cumplimiento, de modo semejante podemos decir ahora, las utopías tienen su cumplimiento: Era utopía que un poeta encarcelado por el sistema socialista llegara a presidente de una democracia, y allí tienen a Vaclav Havel. Era una impensable utopía la Perestroika desde la dictadura de Stalin; utopía era la unión de sistemas políticos antagónicos y allí tienen la unificación alemana. . . Por eso, desde esta perspectiva las características esenciales de la Universidad y su misión ineludible hay que decirlas aunque suenen a utopía, ya que se ha demostrado que si existe determinación las utopías tienen su cumplimiento.

Todos los intentos por definir el carácter específico de la Universidad en buena parte coinciden. "La Universidad es la comunidad de estudiantes y profesores que se reunen para pensar" diría el Cardenal Newman. Y Sartre: "La Universidad está hecha para hombres capaces de dudar." "La Universidad, dice Robert Hutchins, es el espacio recogido para meditar los problemas intelectuales del Mundo" y Karl Jaspers: "La Universidad es el recinto sagrado de la Razón."

70 Se puede advertir que el atributo invariable es "pensar" en sus múltiples modalidades : meditar, dudar, analizar, razonar ... Por eso creo que la expresión más afortunada sobre la Universidad y que no contradice a ninguna de las anteriores, es aquélla que la define como "la conciencia crítica de la sociedad".

La Universidad, conciencia crítica de la sociedad, significa que la misión de la Universidad es pensar (la investigación no es otra cosa que pensar al mundo y a nosotros en el mundo), enseñar a pensar (y ésta es la esencia de la educación universitaria), transmitir y acrecentar el pensamiento (en esto consiste la extensión de la cultura) .

La Universidad como conciencia crítica de la sociedad debe conocer la realidad social en su totalidad, ésta es la materia de su pensamiento; pero esta acción reflexiva sobre la sociedad no termina en el pensamiento, ha de juzgarla y con actitud crítica, denunciar, anunciar, inventar.

Así entendida iqué importante y vital es la Universidad! Por ejemplo, el análisis crítico de la dimensión política. "El arte de hacer vivir a los hombres felizmente en comunidad." Así fué definida la política en una "primitiva Universidad" hace 24 siglos. Y iqué puede decir la Universi- 


\section{LA UNIVERSIDAD: CONCIENCIA CRÍTICA}

dad de finales del Siglo XX de lo que está sucediendo hoy en el marco de la política mundial?

El hecho de que el mundo entero permita que un sólo hombre, y ciertamente no el más lúcido ni el rey filósofo platónico, decida sobre la guerra y la paz, sobre la vida y la muerte, sobre la conservación o destrucción de la casa del hombre, sobre la preservación y destrucción de las expresiones culturales más antiguas de la humanidad; sobre la buena boga o el hundimiento de este barco en el que todos navegamos; .. el simple hecho de permitir que un solo hombre decida sobre cuestiones tan trascendentales pone en evidencia no sólo la crisis sino la quiebra del sistema político internacional .

Y iqué diría de la política que olvida la felicidad de los ciudadanos y pone como valor supremo el poder y la dominación? Ciertamente los griegos de hace 25 siglos hubieran condenado estas decisiones y permisiones como propias de bárbaros, es decir, de subhumanos.

Pero la Universidad en situaciones tan graves ¿qué puede hacer? Ante todo, pienso yo, no debe convertirse en promotora o cómplice de la irracionalidad; y son promotoras de esta irracionalidad las universidades que se someten al poder político, y son cómplices cuando callan. La Universidad debe conservar siempre su independencia, autonomía y libertad para juzgar; denunciar, anunciar e inventar para preservar la independencia y la libertad de la sociead. Por eso se ha dicho con mucha razón que el pueblo que no fomenta la educación superior, que no robustece su Universidad, está destinado a la dictadura. Porque la actitud crítica de los universitarios, de los ilustrados, no sólo de los que aún piensan en las aulas, sino de todos los egresados que son la proyección de la Universidad, constituyen la gran defensa de la libertad. Aunque hay que decirlo también: existen universitarios, ilustrados que caen en el servilismo y éstos son los que generan el despotismo ilustrado; como lo afirma Gabriel Zaid, de períodos de la política mexicana: "El despotismo ilustrado sólo puede sustentarse sobre el servilismo ilustrado."

Y ¿qué puede, qué debe decir la Universidad sobre la dimensión ética donde cada quien se apropia el criterio de bondad, de virtud e infalibilidad o donde, por beneficio de los que manejan el provecho del poder, se niegan la validez y la existencia de toda norma ética? ¿Qué tiene que 
Carlos De la Isla

decir la conciencia crítica de la sociedad sobre el armamentismo (derroche que supera toda ciencia ficción imaginativa) y el hambre, que se ha convertido en la guerra más devastadora y a la que menos atención se ha puesto, porque el clamor de los hambrientos está tan debilitado que ya no merece la promoción televisiva ni el impacto mercantil? ¿Qué tiene que decir la Universidad en su reflexión ética sobre el comportamiento de dominación de los países poderosos sobre los más débiles con el control inflexible del endeudamiento y de todas las debilidades del mundo de la necesidad? Ysi es necesario un serio y lúcido análisis crítico sobre la diferencia de clases entre países ¿qué decir de las hirientes diferencias de clases, grupos y privilegios sociales en lo que nuestro país es un evidente y lamentable ejemplo?

El quehacer, el oficio de juzgar, sin embargo, exigen tamaño y autoridad moral. Por eso una de las funciones más trascendentales de la Universidad consiste en enseñar a pensar y a esto se dirige la formación, la educación universitaria. Esta tarea es todo un arte sutil. No se trata simplemente de instruir, habilitar o moldear ciudadanos útiles a la sociedad. De hecho, el modo en que se realiza la formación define el perfil de la Universidad. Si sólo enseña a pensar los pensamientos aprobados, detalladamente selectos por la ideología institucional; si el proceso educativo es vertical, profético, magistral, receptivo; entonces la Universidad se convierte en reforzadora del sistema establecido, y lo más grave, traiciona su misión analítica, crítica y creadora.

Si por el contrario, ejercita su pedagogía de pensar fomentando el análisis crítico a través del estudio de los grandes problemas intelectuales, si propicia más la reflexión, el descubrimiento y la creación, si funda la educación más en el cultivo de la razón imaginativa que en la memoria, entonces la Universidad está cumpliendo ya, a través de sus profesores, estudiantes, investigadores y egresados su misión de conciencia crítica de la sociedad.

Esta formación que impulsa el desarrollo de la persona en todas sus dimensiones resulta en el momento actual más importante que la información.

Los conocimientos técnicos tienen una vida muy breve y su caducidad se acelera constantemente. ¿Quién no estaría de acuerdo ante esta 


\section{LA UNIVERSIDAD: CONCIENCIA CRÍTICA}

realidad, que la sólida formación analítica y crítica es más importante para asimilar lo nuevo, para aprender a desaprender lo que no tiene vigencia, para ordenar y tomar decisiones ante lo insospechado?

Y ¿qué decir del vertiginoso cambio de nuestro mundo? ¿Quién se atreverá a predecir lo que sucederá mañana? Pues bien, en este mundo en que sólo puede predecirse lo impredecible del cambio ¿qué le queda al hombre que quiera vivir humanamente sino estar preparado, formado para afrontar con lucidez intelectual y con dignidad humana lo que venga? En esto consiste la educación del presente para el futuro.

Tarea ésta vital en el sentido más estricto porque esta educación procura a través del diálogo "el parto de las almas" (expresión de José Vasconcelos); es decir que el estudiante tenga sus propias ideas como sus propios hijos; y porque todo hombre vive de ideas esta formación significa vida propia, y la Universidad en este sentido es generadora de vida humana.

Otro aspecto formativo de la vocación universitaria es el que se refiere a la responsabilidad social. Como conciencia crítica, su quehacer no termina en la reflexión y el trabajo intelectual aséptico y vacío de acción y de vida.

Hay quienes afirman que la Universidad cumple su obligación de justicia con la sociedad cuando forma profesionistas muy capaces en el campo de la ciencia y de la técnica. Pienso que este criterio es, por lo menos, muy discutible, porque si bien es cierto que los buenos profesionistas mejoran el ejercicio de su profesión y ya así benefician a la sociedad, la falla radica en el modo distributivo del beneficio. Los estudiantes que ingresan a la educación superior ya son privilegiados; no importa si se trata de universidades públicas o privadas. Existe una inversión social muy importante y aun sacrificada en las universidades, especialmente en los países pobres y extremadamente pobres. Si esa inversión económica que sacrifica vastas áreas menesterosas de la sociedad tiene como resultado final la afirmación y acrecentamiento de los privilegios a grupos ya privilegiados, entonces la Universidad se constituye en reforzadora de diferencias sociales.

Esto sucede cuando los profesionistas emplean el beneficio de su educación superior exclusivamente para su provecho, soslayando y hasta 
Carlos De la Isla

despreciando el compromiso en justicia con aquella parte de la sociedad que invirtió en su educación superior en espera de un beneficio global.

Subrayo este posible comportamiento porque es muy frecuente esta actitud individualista de los ilustrados y también porque la Universidad a través de sus egresados estaría contrariando su misión. Soy consciente de que la Universidad no puede, no debe hacerse responsable de los comportamientos personales de sus egresados, que en última instancia dependende su libre determinación. Sin embargo, afirmar que la Universidad es neutral o que no tiene influencia alguna en las actitudes de los profesionistas sería aceptar el fracaso de la formación universitaria en los valores intelectuales, estéticos, espirituales y morales que aparecen entre sus fines primarios. Es evidente por otra parte que la huella que deja la universidad elitista, que es una mera extensión de los privilegios de grupos, o la mercantilista, que todo lo ordena a la ganancia económica, es muy diferente a la huella que marca en sus estudiantes la Universidad que comunica con evidencias racionales y con la práctica de un verdadero servicio social, el sentido de la justicia y de la responsabilidad con la sociedad toda.

En esta misma dirección y sentido está el tema siempre escabroso de la responsabilidad del científico. ¿Cómo es posible que pueda sostenerse la tesis de la neutralidad de la ciencia y del científico? ¿Qué conciencia, aún no contaminada, podrá concebir la disyunción entre el descubrimiento científico y el empleo que de él haga el poder político?

Honorato de Balzac, que no es por cierto un severo moralista, escribe: "La conciencia es un juez insobornable mientras no ha sido pervertida." Y si la afirmación es válida para la conciencia individual lo es también para la conciencia social. ¿Qué pensar de los científicos universitarios, ilustrados que simplemente se sienten orgullosos por sus descubrimientos y se desentienden del empleo (muchas veces criminal) que el poder político pueda hacer de él? El inventor de la bomba de uranio (que tiene la virtud, según se dice, de aniquilar a los seres humanos sin afectar la propiedad privada) abiertamente manifestaba orgullo por su invención, con increíble firmeza sostenía: "el empleo de esta bomba, obra maestra de la técnica destructiva, racionalizada, no es algo que me incumba." Actitudes de irresponsabilidad como ésta manifiestan que la ciencia, 


\section{LA UNIVERSIDAD: CONCIENCIA CRÍTICA}

aunque por sí es elucidante (como diría Edgar Morín) debe ser elucidada por esa conciencia crítica superior. $\mathrm{Y}$ ésta es una de las funciones esenciales de la Universidad.

Por otra parte, debemos reconocer que la Universidad tiene un gran poder, el poder moral de la razón; por eso tanto el poder político como el económico intentan la alianza o el sometimiento de la Universidad y para lograrlo emplean medios y argumentos insospechables. La gran defensa en contra del totalitarismo es el poder de la razón, el poder moral de la Universidad. De ahí que sea tan importante que conserve su autonomía, su independencia y sobre todo su dignidad, es decir, su conciencia crítica incontaminada para juzgar a los demás poderes. Y es necesario decir que muchas universidades no han conservado esta independencia ni esa dignidad que otorga la autoridad moral para juzgar; más aún algunas universidades en el mundo entero se han convertido en parte de la estructura política o económica, es decir, han dejado de ser Universidades.

Por último deseo señalar una de las actividades más urgentes de la Universidad. Algunas corrientes contemporáneas del pensamiento discurren por cauces de incertidumbre, inseguridad y a veces de franco pesimismo, respecto a los viejos temas sobre la verdad, la justicia, el bien, la belleza y la paz. Algunos pensadores caminaron desde la llamada crisis de la razón por el subjetivismo, el relativismo, hasta el nadismo.

Aquí una vez más encontramos agigantada la significación de la Universidad como la casa abierta a todos ( $y$ en este sentido es enteramente democrática), a la reflexión enfocada a la invención. Hay muchos campos de la civilización mundial que aún deben ser descubiertos o inventados en la proporción, por lo menos, en que se han encontrado campos pantanosos y arruinados. Urge la reflexión para inventar una política inspirada en el bien de la humanidad y no en la fuerza del poder unilateral y arbitrario, inventar una economía política que resuelva la vergüenza de los antagonismos entre clases de países en elmundo y de clases sociales dentro de los países, los antagonismos entre el armamentismo y el hambre, una axiología construida con valores de la vida, cultura de la vida, del espíritu, de la belleza y de la gracia; urge inventar unas relaciones humanas basadas en el respeto a la pluralidad que logre la armonía de 
Carlos De la Isla

los diferentes y supere la gastada competencia entre hombres y mujeres, competencia de todos contra todos que engrendra las guerras en todos los niveles.

Es urgente inventar un sistema de desarrollo que propicie el progreso de todos y, desde ya, que resuelva la gigantesca injusticia generada por la creciente acumulación de libertad y privilegios de unos cuantos y el acento de la marginación ya intolerable de las mayorías, si se quiere evitar otra explosión violenta, sangrienta (no importa el color y el nombre de la bandera) que reivindique el derecho de los marginados. Y la función de inventar es esencia de la conciencia crítica de la sociedad, de la Universidad.

En esta época de tanta oscuridad en campos tan extensos cuando incluso el Oriente -el Oriente de donde viene la luz está nublado de irracionalidad y vergüenza-es indispensable, es vital que la Universidad, la Verdadera Universidad, siga siendo luz. 


\section{EL POEMA COMO SEMIÓTICA CONNOTATIVA \\ Alberto Perrone*}

He querido decir lo que eso dice, literalmente en todos los sentidos.

A. Rimbaud

Nadie puede escribir un libro.

J.L. Borges

los planos del signo saussureano una forma factible de ser descrita lingüísticamente y una sustancia: aquellos aspectos del fenómeno lingüístico que deben ser descriptos con premisas extralingüísticas. $Y$ ha preferido hablar de la función del signo, más que del signo, colocándola entre dos entidades: Expresión y Contenido; y confirmando que siempre las funciones son solidarias. En cada plano hay, con respecto al significante, una sustancia de la expresión y una forma de la expresión. Para el significado, una sustancia del contenido y una sustancia de la forma. El sistema de significación implica, a su vez, los planos del signo saussuriano y la coincidente imbricación. Para que la connotación sea considerada desde el punto de vista de la comprensión puede ser interpretada como una relación entre dos niveles. Para Greimas y Lévi-Strauss se puede considerar que la connotación se relaciona con la metáfora mediante la metonimia: "un fenómeno de sustitución sobre un fondo de

*FCE, Sao Paulo. 
Alberto Perrone

equivalencia semántica". También según el Diccionario razonado de Greimas-Courtés; al hablar de semiótica connotativa se presupone la explicitación de una teoría llamada a describir los planos del "lenguaje (significante y significado tomados globalmente)" y una sustancia y el referente que introducen variantes. Pero como Hjelmslev radicalizó el formalismo piscologista de Saussure al pensar el signo como función y pasar a considerar Expresión y Contenido, logró un modo de hablar de lo inmanente del signo y de la autosuficiencia del lenguaje. De donde las semióticas connotativas han llegado a ser aquellas que tienen como plano de la expresión otra semiótica, que son sistemas complementarios, de donde Martinet considera que, en definitiva, son algo fundamentalmente diferente.

Por su parte, Cohen retomando a Saussure, Hjelmslev y al mismo Barthes, en cuanto a la busca de un "corpus homogéneo y sincrónico" muestra la correspondencia entre "significante y significado" (Saussure) o "Expresión y contenido" (Hjelmslev): uno como sonido articulado y el otro como idea o la cosa denotada. Este proceso de remisión de un término al otro es el que produce la significación. Se mantiene el criterio saussuriano según el cual la lengua es forma y no sustancia, aún en la posición de Hjelmslev, quien excluyó a las semióticas connotativas del campo de la cientificidad. Habiendo, por otra parte, sido objetado èl intento de Barthes como falto de rigurosidad, aun logrando sugerir "fragmentos connotativos" de lenguas "naturales y contextos" (Greimas, op.cit.).

De todos modos, al observar el planteo hjelmselviano, nuevo sobre la tradición de la Antigüedad, se puede intentar verificar las relaciones trabadas por cada elemento del poema dentro del sistema. Es "dicho conjunto de relaciones -siguiendo a Cohen, en Estructura del lenguaje poético, pág. 33- el que permite a un elemento dado cumplir su función lingüística". De donde se concluye que el lenguaje no es otra cosa que la experiencia reemplazada por una llave que a quienes la saben usar, permite abrir una puerta. Aunque ese abrir se confunda, a veces, con un cruzar y probablemente, en el universo de la locura, entrar para quedarse. El poema se reconoce como un lenguaje que no tiene ni para él, como objeto construido, ni para quien lo creó, ni para nadie, ningún otro lado 


\section{EL POEMA COMO SEMIÓTICA CONNOTATIVA}

además del lado desde el cual ha sido escrito. El poeta, comprendiendo que tiende a ser manejado por esa llave que es su lenguaje, no deja de golperar ante esa puerta y de un modo similar al personaje de Kafka, quien terminó por adevertir que nadie más que él había intententado cruzar ese umbral. Porque sólo a él le aguardaba aunque jamás lograría cruzarlo con vida.

Como lo recordó Barthes en la lección inaugural de 1977, en el Collége de Francia, al decir que Jakobson demostró que un idioma se define menos por lo que permite hablar que por lo que obliga a decir, la labor del poeta, su tarea, es la formalización permanente de resonancias que no se agota en el mensaje, ni en mensaje alguno.

Por su parte, Borges pensó que hubiera deseado escribir, aunque más no fuera, un verso que nada le debiera a sus preferencias y aversiones. Y que por lo mismo fuera irreductible a un análisis ulterior, definitorio. Este deseo, se imaginó el autor de El Aleph, quizá ya existía y había sido realizado varias veces, y no sería otra cosa que el Universo, los universos existentes, conjeturales. Esta paradojal aspiración de originalidad absoluta y de ausencia de remisión a tiempo y espacio sirve para demostrar la imposibilidad manifiesta, en un producto literio, de desprenderse de la connotación. Es este mismo atributo, considerándolo desde el punto de vista de la comprensión, lo que también posibilita una progresiva exploración del poema.

Fue Wittgenstein quien imaginó que los límites del mundo y de sus posibilidades son los del lenguaje. Quevedo antes lo escribió para lo intelectual y lo sensible en su poesía.

Y Nietszche, además, indicó que más que decir "esto es", era aconsejable decir "esto significa". O sea un desplazamiento del ser al existir donde el lenguaje se ha vuelto -y así es observado- la marca, aunque controvertida, de la inmanencia del hombre. Si el lenguaje sustituye a la verdad, a la poesía de la época actual le resta connotar esa realidad con plena conciencia de la incongruencia de la sustitución que realiza. $\mathrm{La}$ otra vuelta de tuerca que el poeta con su poema le hace dar al lenguaje sólo pueder convertir a un texto en poesía.

Fue, por último, Octavio Paz quien escribió que en la esfera de la identidad no existe la metáfora. Aunque quizá no porque como él 
Alberto Perrone

consideró la poética de la analogía sólo puede darse en "una sociedad fundada y corroída por la crítica", sino más bien porque, posiblemente, una sociedad se constituye exclusivamente a partir del lenguaje, vive para él y nada queda fuera.

Paul Ricoeur en Hermenéutica y estructuralismo considera la intención fundamental del signo sobrepasarse ya que el lenguaje, en tanto medio significante, exige referirse a la existencia. Y la metáfora, por su modo de remitir a través vale con su intencionalidad, que suspende y sustituye la referencia del discurso descripto-explicativo, y unívoco, por una polisemia connotativa aunque controlada. Esto último porque, lógicamente, un poema como una metáfora pueden significar algo y no está dentro de su posibilidad significar otras cosas.

Lo poético, quizá se pueda precisar, comienza en el instante en que el término joveneto reemplaza al más habitual jovencito y la sangre puede ser de humo.

Hay que ser un Sócrates o un Carmides, hay que hacer una sabiduría para un joveneto, hay que ofrecer el humo de la sangre ....

(José Lezama Lima)

Aquella palabra ya infrecuente se puede también encontrar en un breve relato nada menos que de César Vallejo. Al desvío del código usual lingüístico en la Retórica se le denominó Figura, "que es la única que ofrece a la poética su verdadero objeto", según el mismo Cohen. Y como también para Saussure en "el mecanismo lingüístico todo rueda sobre identidades y diferencias", la cadena fónica muestra como su primer carácter el ser lineal, y que el oído no distinga interrupciones. Como el hablante considera estable la coincidencia de la detención de la voz.con el sentido, la pausa adquiere también significación: independiza semánticamente las unidades.

Ogden y Richards sostuvieron que el término "sentido" designaba aquello a lo que remite el significante pero, a su vez, subdividido en el objeto real considerado en sí mismo (referente) y el correlato subjetivo del objeto fenómeno mental mediante el cual se lo aprehende 


\section{EL POEMA COMO SEMIÓTICA CONNOTATIVA}

(referencia). Para ellos, la connotación y la denotación poṣeen el mismo referente pero cada una de ellas se opone en el plano psicológico. Una designa la respuesta afectiva y la otra la cognitiva.

\section{Siempre estará faltando \\ la honda mentira \\ el siempre.}

\section{(Idea Vilariño)}

Y se puede incluso ejemplificar con un fragmento de prosa que ha incluido Cohen al citar la Estética, de Hegel:

Puesto que las mismas palabras no son más que signos de las representaciones, no se debe buscar el verdadero origen del lenguaje poético ni en la elección de las palabras y el modo de unirlas para que formen oraciones y períodos, ni en la sonoridad, el ritmo, la rima, etc., sino en la modalidad de la representación.

Las anteriores citas permiten advertir una diferencia de "modalidad de là representación" provocada por una diversa selección y conmutación aplicada en la cadena del habla. Si las palabras son las funciones de las representaciones cada una de ellas guarda un doble sentido posible: denotativo y connotativo. En los diccionarios se tiende más a un acercamiento al primero, pero no sería imposible suponer -en cuanto existen diccionarios de rimas-otro diccionario que incluyera signos connotativos donde las palabras se pudieran definir por sus cualidades afectivas, al menos en un corpus socio-temporal. Ahí "rojo" significaría "excitante" y "azul", se consideraría "sedante".

En consecuencia, "si la poesía está hecha de figuras y si las figuras son violaciones del código denotativo -reflexiones que devienen de Saussure, Hjelmslev, Greimas hasta llegar a Cohen- entonces resulta que la negación denotativa es la condición de la posición connotativa. Y resultan antagónicas al no darse una simultánea respuesta emocional e intelectual, al mismo tiempo. O la intelección de la poeta uruguaya en 
Alberto Perrone

cuanto poeta o la del filósofo alemán, como tal. Como el mismo Cohen destacó para que concuerden las connotaciones hace falta además, que se actualicen, cosa que no se puede dar más que si las denotaciones les ceden su lugar.

El cambio de sentido del "siempre" invierte un paralelimo del hábito. "Para mí -dijo Breton- no lo oculto, la imagen más vigorosa es la que presenta el más alto grado de arbitrariedad." Lógica e ilógica producen una emocional significación poética. Borges en el prólogo a Fervor de Buenos Aires, en 1923, había pensado: "Siempre fui novelero de metáforas, pero solicitando fuese notorio en ellas, antes lo eficiente que lo insólito." Matiz diferencial frente a la propuesta del Surrealismo. Y tanto él, como el poeta paraguayo Elvio Romero destacaron que en las antiguas lenguas se pudo decir "camino de la sangre" para denotar, en el sentido de agotar al objeto, una "lanza" y, en consecuencia, lógicamente es posible pensar que pudieron aparecer los dos tipos de respuestas.

En el mundo de la latinidad se señalaba el músculo del brazo humano y lo llamaron musculus, que significa "ratoncito". Un sistema semiótico, pero regresivo, que desea cruzar aquel umbral buscando un estado presemiológico donde encontrar esa morada dentro de la cual se supone que aguarda el sentido de las cosas, no ya de las palabras. Por eso también la literatura adquirió cada vez más pronunciada tendencia hacia el antilenguaje para -supuestamente-captar el en-sí de la cosa.

Esta profundización en el campo de la lingüística se viene enfatizando en los últimos 50 años. Intentos de delimitar un problema ya resultan un decidido avance en relación con lo que pensó la Antigüedad. Aristófanes, en Las nubes, es el remoto antecedente para referirse a un ejemplo de comparación acuñado por el poeta; después la problemática se encuentra expuesta en las Epístolas de Horacio. Sin desconocer que Platón y Aristóteles habían iniciado la reflexión sobre el que "hacer bien las metáforas es percibir las relaciones de semejanza" (Poética); y que Cicerón enfatizó la actividad sensibilizadora de la imagen y advirtió la distinción entre metáfora y metonimia que, mucho después, con la actividadad del Formalismo ha tenido especial importancia.

Aunque para Cohen se viene destacando la sustitución (connotación) del aspecto intelectual por el afectivo (emotivo) y se marque el antago- 


\section{EL POEMA COMO SEMIÓTICA CONNOTATIVA}

nismo entre ambos, al extremo de que uno debe obligatoriamente desaparecer para que el otro se cumpla, hay quienes (Hjelmslev, Barthes, Greimas, entre otros) optan por una connotación como sistema significante desenganchado de una significación primera. Aludida en ese prefijo co-notación, en cuanto a lo que está presente, sin tener que desplazar a la otra significación coexistente y, al mismo tiempo, sin necesidad tampoco de ser algo expresamente opuesto.

El estado de investigación en que se halla esta concepción también se puede comprobar en la imposibilidad que muestra Cohen para resolver completamente, y él lo reconoce, los dos códigos donde intenta su definición de poesía. Le falta encontrar la combinación simétrica del enunciado absurdo.

De este modo, sentido y fenómeno se presentan indisolublemente unidos en las Ciencias Sociales. Dilthey dice que "Para determinar el concepto de poesía, lo tengo que abstraer de aquellos hechos que constituye la extensión de ese concepto... una característica por la cual reconozco que la obra es poética". Justamente este pensamiento está en la base fenomenológica husserliana que prosiguió la reflexión semiótica en sus variadas inflexiones. En esta línea se ha retomado también a Dilthey quien consideró los fenómenos humanos sujetos a un sentido y a la intersubjetividad. Por lo que las Ciencias Sociales o Humanas alcanzan cierto grado de objetividad. Porque la experiencia del sujeto no puede restringirse como cuando las reglas experimentales acotan y fijan su aparición bajo determinadas circunstancias. Por lo cual la función Pragmática de quien enuncia (Wotjak, Mignolo) es fundamental. Y resulta productiva la observación de que el discurso es "una inversa coordinación de enunciados... Pone en evidencia las restricciones, particularmente las semánticas, a las cuales están sujetas las secuencias de enunciados" (Cohen).

Y se sigue a Buxó cuando se acepta -con Hjelmselv y Benveniste-que "la lengua es el único medio de análisis de la sociedad, no se quiere afirmar que las estructuras semióticas de la lengua determinen, sin más, las estructuras sociales, sino que éstas son interpretadas por una lengua y estructuradas de conformidad con su propio sistema semiótico". Si inicialmente Hjelmslev consideró que cuando se "procede al análisis 
Alberto Perrone

científico de la 'sustancia', ésta se convierte forzosamente en 'forma' ..cuyo complemento es también una 'sustancia' que comprende, una vez más los residuos que no han sido aceptados como marcas constitutivas de definiciones". Elementos teóricos para reforzar la proyección de un pensamiento que llama la atención sobre un exceso, la pura negatividad del residuo aparece pasible de volverse poesía.

Al haber invertido Barthes la inicial propuesta de Saussure por la cual era concebible "una ciencia que estudie la vida de los signos en el seno de la vida social" (la Semiología) se la terminó por convertir en parte de una Lingüística como ciencia de las siginificaciones. Al extremo que un congreso reunido en París en 1969, se pronunció por la utilización del término Semiótica para la Ciencia de los Signos, tendiendo a disminuir la ambigüedad que devenía de la lógica de Peirce, Mills, et alii.

Esos golpes sangrientos son las crepitaciones de algún pan que en la puerta del horno se nos quema.

(César Vallejo)

Estos versos pueden ejemplificar esa clave que todas las figuras poéticas exhiben de la antinomia denotación/connotación y que resulta siendo un cambio de sentido y función. El sentido habitual de un "golpe", de "sangre", de "crepitaciones", etc. es el sentido denotativo que se ha vuelto no-pertinente en el poema "Los heraldos negros" cuya pertinencia sólo les devuelve el sentido connotativo. Por lo que se puede leer un poema construido a partir de figuras que no son más que desviaciones del código denotativo. Y como ha sido Jakobson, por su parte, quien consideró que el principio de similitud gobierna el poema, resulta que la metáfora -basada en ese principio- ha terminado por ser consagrada, al menos para los estudiosos como la figura más importante. Porque son las figuras por semejanza las que permiten reconocer una relación de identidad, que es también de indiferencia. 


\title{
EL POEMA COMO SEMIÓTICA CONNOTATIVA
}

\author{
Y $\mathrm{Li}-\mathrm{Po}$ \\ el divino \\ que se \\ bebió \\ a la \\ luna \\ una \\ noche en su copa \\ de vino.
}

(José Juan Tablada)

Como se sabe, lo que habría de llamarse "Estridentismo" fue en México un movimiento de vanguardia literaria, pero lo que es útil considerar, resulta del descubrimiento del haiku japonés que se realizó a partir de la estadía de Tablada en Oriente, en 1903. En él, como en los que se agruparon en aquella vanguardia, existen elementos para preguntarse por la nueva forma que el poema comienza a mostrar. La publicación del libro $L i-P o ́$, en 1919, es un antecedente y se lo debe considerar en relación con lo que realizan Apollinaire y Vicente Huidobro. Cuando Huidobro llega a París, en 1916, se incorpora a la revista SIC junto con Apollinaire, Reverdy, Breton y Aragón. Es cuando la dimensión orientalista, e ideogramática de la escritura sueña con un regreso a ese pasado de la humanidad donde encontrar el primer lenguaje. De ese propósito, surgió a su vez el Dadaísmo y el Surrealismo. En la medida en que la modernidad utiliza una escritura fonética-vehículo histórico del concepto- habrá un estrato anterior de la esritura ideográfica y algún otro más que pueda conducir el poema al jeroglífico.

Un gesto de vanguardia que rubrica desde el mismo nivel gráfico del poema lo que la obra literaria no puede dejar de ser: un círculo de información -gráfica o fónica- enmarcada, que no han hecho otra cosa que comprobar Mignolo, Kristeva. Para esta última, el enunciado poético no resulta legible en su totalidad significante más que como una puesta en el "espacio" de unidades significantes. De donde cada unidad logra un lugar claramente definido e inalterable en el todo del poema. Preci- 


\begin{abstract}
Alberto Perrone
samente, ella lo ejemplificó con Stéphane Mallarmé y su recordable Un coup de dés... Este "lance de dados" ...es otro antecedente de los intentos de una sintaxis espacial en la concepción del poema como objeto concreto visual. Una incorporación de la tecnología publicitaria de la época y la adopción del ideograma como método de composición basado en la yuxtaposición directa, analógica y no siempre discursiva de las palabras. Joyce y Cummings, por un lado, hasta los poetas brasileños -no casualmente a uno de ellos (Haroldo de Campos) fue a quien le remitió nada menos que Jakobson su carta-ensayo sobre la textura poética, que se vino a divulgar al incluirla en sus Ensayos de poesía-como la insistencia de Roberto Juárroz en denominar a la continuidad de sus libros Poesía vertical.
\end{abstract}

Ave
cantá
suave
que tu canto encanta
sobre el campo inerte
sones
vierte
y ora-
ciones
llora
desde
la cruz santa

("La capilla aldeana", de Vicente Huidobro)

El escrito vanguardista de Huidobro, Non serviam, cuya discutible datación el chileno ubicó en 1914, prorrumpió enfáticamente en el carácter crítico del movimiento poético que denominó Creacionismo. Para él, "el poeta es un pequeño dios", y existe una convergencia entre arte y ciencia. La filosofía de Emerson, y también la Bauhaus en Alemania, en 1919, posibilitaron este credo; así como entre los italianos, y en Rusia, 


\section{EL POEMA COMO SEMIÓTICA CONNOTATIVA}

aparecen las variantes del futurismo. Una sintética ubicación para evidenciar que la revista Creación cuyo primer número editó Huidobro en París y los dos últimos en España, durante el lapso 1921-24, puso el acento en la idea del universalismo idiomático. Tablada buscó reprodocir ese género poético sumamente breve, formado por una sutileza métrica de efecto simbólico que, al menos antes del japonés Basho (siglo XVII) pertenecía al orden humorístico o al menos, irónico: el haikú. Y Luis Quintanilla recogió, por su parte, en Avión, textos que vistos desde esta perspectiva, evidencian, como los cuadros pintados por los Impresionistas los puntillistas o, más tarde, por los Cubistas, idénticos planteos: lo caligramático lo ideográfico, la renovación también por el humor. La Universidad de Columbia le encargó a Octavio Paz una revalorización de Tablada, que influyó a su vez en el poeta consagrado con el Nobel.

La infrecuente disposición del fragmento del poema "La capilla aldeana" de Huidobro -que el crítico Noé Jitrik también estudió- corrobora postulados que se caracterizan por destacar -como nunca antes- la materialidad del poema. Probablemente, no la inventa, como seguramente él hubiera aspirado, pretendiéndose un adelantado de la modernidad. Pero la puso de relieve de un modo que ya no se volverá a desconocer, ni por los poetas, ni por los teóricos. Lo que posibilita continuar, aún en la actualidad, estas reflexiones. Tanto las connotaciones objetivas tipográficas como las de producción de una metáfora, el "ave" canta por el hombre que "reza" es la sustitución de un término por otro sobre la base de un eje semántico -para emplear la terminología de Greimas- ese semántico intermedio, el canto, es un "sema" implicado. Como ha propuesto además Jakobson, también aparecen indicadas consideraciones sobre el "contexto" de esta obra en un sistema de elementos que han comenzado a designarse como "intertextuales". El imperativo singular, "canta", pasa por una transición dentro del paradigma musical implícito que posibilita que se transforme en el plural "sones" y entrelace una rima que enlaza a "santa". Un enlace sonoro (o musical) que no puede dejar de ser influencia -admiración y rivalidad-de Rubén Darío, nunca más que en aquel período considerado, indiscutiblmente, un horizonte de realización para los hispanoparlantes. Aspectos cruciales en un poema que intenta ir a contramano del canon 


\section{Alberto Perrone}

gráfico y perturbar también en lo sonoro, la inicial certidumbre del "canto". Y mantiene -como Tablada- un aspecto cómico del efecto fónico, aun en la exasperación del ordenamiento tipográfico que, rellenando de palabras la caligrafía destaca en la parte superior una cruz, continúa hacia abajo de la página el desarrollo total del poema "La capilla aldena". Posición que tiene vasos comunicantes de época, el efecto aparece increíblemente incrustado en el dibujo de la cruz y surge al leer fonéticamente "y ora", del mismo modo que "llora" u "iora", que anticipa en su nivel la palabra que repite el parante y que ungolpe de vista permite leer, más abajo: "llora". La visión de esa emblemática cruz, los sonidos observados y la misma separación de una de las palabras connotan otra relación, contrapuesta, al "canto suave" y al "campo inerte". Modo de verificar la posibilidad de este fragmento significativo, en cuanto a constituir un nuevo lenguaje en la medida en que crea objetos, los insinúa y propone distintas relaciones entre ellos.

Ya Mignolo destacó cómo Amado Alonso advirtió anomalías sintácticas en Neruda: miembros coordinados que están obligados a pertenecer idiomáticamente a una misma categoría, no siempre, lo cumplían. Otro antecedente para el chileno, que aspiró a encontrar rupturas equivalentes y que las halló en el orden fónico y visual, aunque difícilmente, esta formalización del poema como objeto facilite su tradicibilidad. Sin embargo, y esto es destacable, fue una aspiración de vanguardia que quedó con escaso desarrollo frente al criterio que cada lengua construye sus propios objetos, y eso es parte del problema de vertir un poema a otra lengua. Pero queda la vocación caligramática que prosiguieron Tagore, Michaux y llegan a los intelectuales intentos del uso de la computación. Manteniéndose, en todos los casos, la construcción del poema como una forma donde se visualiza al objeto por una asociación de similaridad instántanea.

Ha sido también esa vocación por el caligrama la que intentó imponerle a la percepción del poema una nueva forma, totalizante, que se engarzó en una denominación figurada, tanto como en una denominación propia.

En el fragmento considerado, la palabra "ave" permite comprobar la 


\section{EL POEMA COMO SEMIÓTICA CONNOTATIVA}

función de la connotación en el hecho poético. Funciona para ser leída como uno de los nombres de Cristo. El poema continúa:

el triunfo del sol canta

y bajo el palio azul del cielo

deshoja tus cantares sobre el suelo.

Une tus notas a las de la campana

Que ya se despereza ebria de mañana

Evangelizando la gran quietud aldeana.

Es un amanecer en que una bondad brilla

La capilla está ante la paz de la montaña

Como una limosnera está ante una capilla.

Se esparce en el paisaje el aire de una extraña

Santidad, algo bíblico, algo de piel de oveja

Algo como un rocío lleno de bendiciones

Cual si el campo rezara una idílica queja...

("La capilla aldeana")

Si hasta en pintura -como apreció Jakobson- el realismo es una invención, es infructuoso entonces preguntarse sobre el grado de verosimilitud del caligrama (sugerido tipográficamente con la silueta de una capilla, la Cruz en lo alto y el zócalo en el remate inferior), tanto como por la mayor o menor fidelidad de uno u otro tropo. El teórico ruso, además, consideró cómo una tradición convierte a una imagen en ideograma. Desde el momento en que se está obligado, por el contrario, a recurrir a la metáfora, a la alusión, a la alegoría es porque se desea obtener una fortalecida forma expresiva.

Si el corpus del poema -aun una esta visión fragmentaria- logra la mímesis por su aspecto, es porque el lector tiene una experiencia de objeto-cruz. Con aspas en el remate sería un molino, y existen ejemplos. De este modo, las relaciones de motivación que tienen los significantes entre sí, y sobre todo los tropos entre sí, terminan por desencadenar una serie que se pretende ininterrumpida de imágenes, cuyo devenir y, por 
Alberto Perrone

continuidad de los mismos tropos, remite al nacimiento del Surrealismo: la poesía como una manifestación especial de mutuo engendramiento. En el poema la metáfora actúa como reproductora de metáforas que se vale, incluso, de un código que puede considerarse mimético (por representativo de formas objetivas de la realidad) y que para algunos teóricos constituye también la prosa.

En consecuencia, ese primer sistema que utiliza el poema y que pertenece al lenguaje de la sociedad porque es en ella donde el escritor ejerce su acto de habla, ha sufrido una elaboración para integrarse al código literario que, por un lado, ratifica un sistema de connotación religiosa $y$, por otro, lo alude irrespetuosamente.

Esta consideración de lo que resulta apropiado o no, en cierto momento y para cierto sistema, también queda aquí de manifiesto como significante específico del poema.

Freud dejó establecido, al menos dentro de su semiótica, que el sentido segundo de la conducta es el propio. Por esto mismo, para Barthes, la poesía contemporánea aparece en un sistema semiótico de connotación regresiva. Su tarea, que para algunos siempre es advertida al borde de la extinción, nace del constante enfrentamiento con la sociedad que permanentemente realiza en el uso una disolución del valor metafórico del lenguaje.

Doble código de Cohen para definir la poesía

pertinencia

\begin{tabular}{lcc}
\hline fase & connotativa & denotativa \\
\hline prosaica & - & + \\
absurda & - & - \\
poética & + & -
\end{tabular}




\section{EL POEMA COMO SEMIÓTICA CONNOTATIVA}

Este gráfico tiende a convertirse en una ecuación matemática. La Prosa es el resultado de un "más" denotativo por un "menos" connotativo; la Fase Absurda de un "menos" por un "menos"; y la Fase Poética resulta de un "menos" denotativa por un "más" connotativa.

El estado de búsqueda científica se observa en la falta de una simetría que complete el gráfico. Y resta como interrogante, que el autor no se plantea, cual podrá sèr la Fase "más" por "más".

La capilla aldeana, de Vicente Huidobro:

Ave
canta
suave
que tu canto encanta
sobre el campo inerte
sones
vierte
y ora-
ciones
llora.
Desde
la cruz santa
el triunfo del sol canta
y bajo el palio azul del cielo
tus notas a las de la campana
ya tus cantares sobre el suelo.
despereza ebria de mañana
amanecer en que una bondad brilla
amano la gran quietud aldeana.
uilla esta ante la paz de la montaña
una limosnera está ante una capilla.
algo bíblico, algo de piel de oveja
mo un rocío lleno de bendiciones
el campo rezara una idílica queja




\section{Alberto Perrone}

Llena de sus caricias y de sus emociones.

La capilla es como una viejita acurrucada $\mathrm{Y}$ al pie de la montaña parece un cuento de hada. Junto a ella como una bandada de mendigos Se agrupan y se acercan unos cuantos castaños Que se asoman curiosos por todos los postigos Con la manevolencia de los viejos huraños. Y en el cuadrito lleno de ambiente y de frescura En el paisaje alegre con castidad de lino Pinta un brochazo negro la solana del cura.

Cuando a la tarde alarga su sombra sobre el camino Parece que se metiera al fondo de la capilla Y la luz de la gran lámpara con su brillo mortecino Pinta en la muralla blanca como una raya amarilla. Las tablas viejas roncan, crujen, cuando entra el viento oliendo a rosas Rezaga triste en un murmulio el eco santo del rosario La obscuridad ya amalgamando y confundiendo así las cosas $\mathrm{Y}$ vuela un "Angelus" lloroso con lentitud del campanario.

(Para Alita revoloteando escalas mecánicas de puertos encantados.) 
NOTAS

\author{
LA SUBJETIVIDAD Y EL \\ CUERPO, UN ENSAYO SOBRE \\ MERLEAU-PONTY \\ Eduardo González Di Pierro*
}

\title{
El ente racional finito no tiene nada
} fuera de la experiencia. Ésta es la que contiene toda la materia de su pensar. El filósofo se halla necesariamente en las mismas condiciones. Parece, según esto, inconcebible cómo pueda elevarse por encima de la experiencia.

\section{Johann Gottlieb Fichte}

\section{Introducción}

L a tendencia general de la filosofía contemporánea puede muy bien resumirse en el título de la obra de Jean Wahl, Hacia lo concreto. Así, el pensamiento de Husserl creó una modalidad de pensar diferente de una doctrina o lo que pudiera llamarse una ideología; la fenomenología y su lema "a las cosas mismas" forman un corpus

*El Colegio de Michoacán. crítico de alcances importantísimos para el desarrollo de la filosofía.

Al mismo tiempo, la aparición de la filosofía de Bergson dirigida hacia los datos inmediatos de la conciencia, se une a las consideraciones fenomenológicas para realizar una importantísima inversión del platonismo y de su desatención a las particularidades como fuentes de significación original.

Hacia lo concreto, igualmente, se dirige Heidegger con su in-die-Weltsein y, ¿por qué no?, Freud y el psicoa- 
NOTAS

nálisis que funda una psicología de lo concreto dirigida a una tambaleante concreción humana poblada por fantasmas.

Pero, sin duda, el expositor más brillante y lúcido de esto que llamamos "filosofía de lo concreto" es Maurice Merleau-Ponty; la relación que establece entre el hombre y el mundo es de una radical originalidad. Superando la misma relación sartreana que sitúa al mundo frente al hombre, MerleauPonty en su reflexión fenomenológica devuelve la consustancialidad del sujeto y el mundo, del sujeto y $s u$ mundo. El mundo no es exterior al sujeto, que forma una amalgama primigenia con él; el percibir se constituye como acceso a lo que ya somos, introducción a un mundo particular formado de virtualidad, de posibilidad.

El sujeto y su campo (lo subjetivo) son, para Merleau-Ponty, la constitución misma del filosofar; el sujeto, que es cuerpo, introduce la anomalía de lo verdaderamente humano y muestra orgullosamente la virtud de lo ambiguo. La relación entre sujeto y cosmos es una relación de filiación. Sólo la reflexión y la percepción original pueden dar cuenta del misterio; sólo vivir explica la vida; las sustancias se tambalean, la objetividad pura se quiebra.

El hombre nace al mundo que es él, por la riqueza significativa de su cuerpo concreto. A partir de una reflexión de esta naturaleza, que es estética, podemos vislumbrar la verdadera naturaleza del filosofar: la creación de problemáticas y derivaciones como ética y epistemología.

La ontología merleaupontiana es una ontología estética, perceptiva; el origen del ser está en el percibir, la subjetividad se une para representar al torbellino humano y el ser no es el pleno engañoso, sino la falta positiva.

Lo concreto de que hablábamos se revela en Merleau-Ponty como lo expresivo; él no pretende la fundación de una cosmología, de una teoría del mundo, sino una especie de teoría sobre la reflexión de nuestra experiencia perceptiva y tal es nada más la consideración del mundo; así como no hay un puro a priori formal, trascendental, tampoco hay un empirismo radical: en ambas posiciones está el defecto de la exclusión de la subjetividad como constitutiva del filosofar mismo y la desconsideración del cuerpo como acceso al mundo (salvándose de esto último solo Spinoza). La subjetividad y *el mundo constituyen el estilo de habitar un mundo que no nos es ajeno, un mundo que es prolongación de nuestra corporalidad, de nuestra carne.

\section{Subjetividad y filosofía}

Hay que comenzar destacando el interés prominente, auténtico y sincero que Merleau-Ponty siente por la filosofía, por lo filosófico; la prueba no se encuentra únicamente en su magnífico Eloge de la Philosophie, sino también en sus obras más específicas; hay una 
apología constante del ejercicio filosófico en Merleau-Ponty. Esta apología consiste en una aguda e intensa reelaboración y reconsideración de los conceptos y las categorías desprendidas de la filosofía. En efecto, MerleauPonty reconstruye y replantea problemas constantemente, los convierte y los cualifica; lo que escépticos y positivistas tachan de defectuoso es señalado por él como característica positiva y virtuosa de la filosofía. Senala siempre como peculiaridad de la problemática filosófica la presencia de la relatividad como elemento constitutivo de la verdad y no como un obstáculo para la verdad; más aún, es lo que posibilita el ejercicio de la filosofía: no existe la verdad absoluta ni lo "absolutamente absoluto".

Se puede objetar que la objetividad de la filosofía se pierde y el ser, su objeto más caro, se destruye, pero, por el contrario, la introducción de este relativismo así concebido, supera los embrollos y equívocos en que había caído; se trata del encuentro más genuino con el ser, pues hay un elemento que resquebraja su sospechosa plenitud: la subjetividad.

En las llamadas "filosofías de lo absoluto" está también presente el elemento subjetivo; la cuestión subjetiva-emerge aun en los más áridos campos de la totalidad. La tradición ve negativamente todo relativismo, considerándolo como defecto. Sin embargo, es lo que constituye al discurso filosófico: "Percibimos una filosofía, es decir, sólo accedemos a ella desde una determinada perspectiva." ${ }^{11}$ Esta sencillísima razón destruye la pretensión unificadora de una filosofía "pura" que excluya al sujeto y sólo admita la pobreza numeraria de las estrictas dicotomías.

Merleau-Ponty intenta dejar en claro, con su característica sobriedad, que la problematicidad de la filosofía es, por sí misma, su esencia. Todo relativismo es, para Merleau-Ponty, ontológico: el ser es un fenómeno inseparable del sujeto, pues está en relación con el sujeto, dándose así el perspectivismo arriba citado, como condición de la expresividad del mundo; éste se torna expresivo cuando interviene la relación entre él y el sujeto (más adelante diremos cómo está constituida tal relación).

El ser pleno es nada pues nada deviene; entonces el ser parmenídeo es nada en realidad: cuando postula, en su clásica cita, "el ser es y el no ser nada es" está estableciendo una diferencia cualitativa en apariencia, que queda anulada en el mismo momento en que señala cuáles son las atribuciones del ser: inmutable, inmóvil, uno, único, eterno, contínuo, imperecedero, indivisible.

La afirmación de Parménides se convierte así, a la luz de lo que hemos hasta aquí expuesto, una contradic-

\footnotetext{
${ }^{1}$ M.T. Ramírez, La filosofia del quiasmo, 1985, México, UNAM, tesis de maestría en filosofía, p. 7.
} 
NOTAS

ción, porque decir que el ser es inmutable, inmóvil, etc., es decir, de acuerdo con lo dicho, que en realidad, no es el ser, pues, según la perspectiva merleaupontiana, para que haya potencialidad y devenir es necesaria la subjetividad y, como variantes de la relatividad, debemos unir temporalidad, historicidad, percepción... No hay, en conclusión, filosofía si no hay una dosis importante de subjetividad; asumir la relatividad es un buen punto de partida para un fructífero ejercicio de la filosofía.

Aun las filosofías más absolutistas arrastran consigo, para su existencia, este elemento. Tomemos como ejemplo a Bergson: interpretaciones erróneas la definen "absoluta" al suponer al ser como un "ser pleno" en donde la nada queda devaluada, ${ }^{2}$ apareciendo así una plenitud. Lo que debe oponerse a la filosofía bergsoniana no es una pura negatividad sino precisamente esa ambigüedad. Merleau-Ponty afirma que las observaciones del propio Bergson matizan ese pretendido absolutismo. El matiz más importante es la teoría de lo problemático, del planteamiento de los problemas, la invención y creación de cuestiones; es la vía intuitiva, $\tan$ cara a Bergson, la que opera esa introducción a lo expresivo de la problemática, de la maraña que es el discurso filosófico; y lo problemáti-

\footnotetext{
${ }^{2}$ Nos referimos aquí, desde luego, a la nada pensada en términos dialécticos, pues la nada pensada en términos fenomenológicos es indubitable.
}

co que está presente en Bergson está presente también en nosotros, como en el exterior y en la naturaleza.

Por lo tanto, a partir de lo anteriormente expuesto, dejaremos de hablar de una ausencia del sujeto o de una subordinación de éste al ser, para hablar de una coexistencia, de una concordancia; de una multiplicidad de duraciones con mi durée a la cabeza, sin perderme ni extasiarme con una duración universal, pretendidamente plena, eterna, absoluta. La filosofía es más $\alpha \rho \chi \tilde{\eta}$ que $\tau \hat{\eta} \lambda o \sigma$ : la valorización de un pasado que opone y enfrenta su consistencia a dos purezas extremas: la positividad pura del presente y la negatividad pura del futuro.

Pero ide dónde nos viene el "sentido primero del ser"? Merleau-Ponty corona su exposición afirmando que el significado primigenio del ser viene precisamente por el simple hecho de ser nosotros, refiriéndonos con esto al hecho de percibir. Comenzamos a llegar a la cuestión central. La percepción es el saber absoluto; al afirmar esto llegamos a una paradójica conclusión: el saber absoluto no es algo absoluto. El percibir es lo originalmente subjetivo, la entrada al ser. El acceso ontológico es "natural", ingenuo y tranquilo y no un artificioso "campo de saber". La percepción no supone un puro mirar pasivo, privado de la acción.

En primer término, la receptividad es, para Merleau-Ponty, otra virtud, una ventaja, pues no supone una pasi- 
vidad sin más sinó una verdadera "acción subjetiva"; en segundo término, el cuestionamiento que nace con la percepción no es privativo únicamente del sujeto, sino también pertenece al objeto; lo receptivo es gozoso por recíproco.

La percepción se constituye como una relación obsesiva con el ser, naturalmente indisoluble; en todas las esferas de la acción humana es visible esto: estoy obsesionado por mi amada, a la que no tengo en este momento preciso pero que, a la vez, llevo dentro constantemente, formando parte real de mí. ¿Por qué, entonces, busco poseer algo que ya, de entrada, tengo? Justamente porque pensamos que somos exteriores a las cosas, porque nos creemos objetos entre objetos; relaciones que hay que inventar; lo único que se inventa son pensamientos; hecho esto, nuestra relación con el mundo deviene originaria. Accedemos al reino de lo expresivo.

La relación entre el mundo y el sujeto es un intercambio auténtico entre yo y el mundo, entre el yo y la alteridad y este intercambio tiene sentido y cobra significación por la percepción; la relación se da a nivel fenoménico, coincide con las cosas porque éstas devienen expresivas de mí, dando lugar al quiasmo:

La percepción es la relación quiasmática misma, es el campo relativo, ambiguo y paradójico por excelen- cia. La dicotomía clásica sujetoobjeto (o cuerpo-alma) se modifica de una manera total si la pensamos en el campo del ser sensible: entre el sujeto sensible y el mundo sensible no hay relación de exterioridad, causalidad o reducción (...) hay sobreposición, mutua incorporación o doble referencia. ${ }^{3}$

Este quiasmo, esta sobreposición positiva, surge cuando surge la diferencia o, más exactamente, al comprender la propia diferencia como cualitativa (distinción real), formal, intensiva; así se comprenderá la relación expresiva mundo-sujeto, a partir del parentesco que Deleuze establece entre Merleau-Ponty y Spinoza, cuando habla de la "idea de infinito positivo" como la gran aportación actual de Merleau-Ponty "que alcanza su perfección en el spinozismo", en donde podemos distinguir la sustancia expresada en atributos, atributos en modos... y cuyo corolario más importante es la corrección del cartesianismo que concibe sustancias separadas con modos respectivos. Spinoza, a partir de su concepción de la Sustancia es, sin embargo, el primer antisustancialista.

No hay bloques estructurales, soportes diferentes, campos separados. $\mathrm{Y}$ aquí viene la conexión. Merleau-

${ }^{3}$ M.T. Ramírez, op.cit., p. 34.

${ }^{4}$ G. Deleuze, Spinoza y el problema de la expresión, 1975, Barcelona, Muchnik ed., p. 24, igualmente citado por Ramírez, op. cit., p. 58. 
NOTAS

Ponty concibe un universo sin sustancias separadas, sin estructuras independientes que expliquen a partir de sí la realidad; la percepción está antes que esas quiméricas creaciones y aún le precede el lenguaje, como a continuación veremos.

\section{Subjetividad y lenguaje}

El mundo y el sujeto, entonces, están en comunión, forman sistema, y accedo a los otros a través de mi cuerpo y no a través del puro pensamiento, es decir, no por un puro acto de analogía como quiere Husserl, ${ }^{5}$ porque son expresivos de mí, es decir, me habitan. No es que compartamos al mundo, puesto que somos el mundo mismo. Como dice Merleau-Ponty en Signos, los demás son relieves, son pliegues, variaciones de una pura realidad de la que yo formo parte o, mejor, de la que yo participo (expresivamente), "gemelos míos, carne de mi carne". La percepción de los otros se da inmediatamente, es decir, esa relación fenoménica de la que hablábamos se refiere, en sentido estricto, al plano de la apariencia: mostrarse-uno-a-otro. Si la reciprocidad es plena, no somos

${ }^{5}$ Cfr. E. Husserl, Meditaciones Cartesianas, 1986, México, F.C.E., 5a. meditación: Hay una parte en que Husserl da por supuesta la exterioridad irreductible de los otros, negando que me habiten, cuando dice, en un paréntesis: "sobre todo la cuestión de la posibiliđad de cómo llego yo desde mi ego absoluto a otros ego que, como otros, no existen realmente en mí sino que en mí hay sólo conciencia de ellos" (p.150). parte de lo mismo; se trata, pues, de reciprocidad interexpresiva; somos símbolos expresivos de las cosas y no una relación objetiva-física-empírica de pura disolución, y esto presupone la subjetividad.

Estrechamente emparentado a lo anterior está el pensamiento de Emmanuel Levinas cuando habla acerca de la significación y el sentido. En efecto, Levinas, toma como punto de partida para sus consideraciones acerca de la alteridad en su libro Humanismo del otro hombre, a Merleau-Ponty; pretende realizar una negación de las totalidades como entidades separadas, considerando, de esta manera, una totalización, sí, pero no analítica, no cuantitativa, sino una "totalización intuitiva" en la que nuestro cuerpo es el mundo y es la posibilidad; no hay funciones corporales que estén ceñidas a un grupo privilegiado y correspondiente de objetos, así como no hay significados dirigidos a determinados significantes: he ahí la posibilidad de la metáfora, de la riqueza de sentido.

Somos responsables de lo que percibimos, pues nuestro cuerpo unifica al ser (de ahí que no sea pleno) a partir de sus gestos, de sus virtualidades, de sus acciones. El cuerpo, para Levinas, como para Merleau-Ponty, es dual: percibe y expresa; percibe porque expresa, anulando la estricta dicotomía sujeto-objeto e introduciendo la hermosa ambigüedad de las imperfecciones. El cuerpo no sólo recibe, crea, más aún, su recibir es ya un crear, su 
NOTAS

receptividad es su forma de acutar; $y$, antes del mero percibir objetos, hay una instancia que unifica al ser, que engloba percepciones: la instancia del lenguaje. Para ambos filósofos los objetos significan por el lenguaje y no al revés. Que una significación esté unida a un contenido correspondiente responde a un simple bloqueo del pensamiento, una interrupción de la creación, una fractura de la intención.

Merleau-Ponty, ya lo sabemos, afirma que la percepción sin más es nuestro acceso original al mundo; pero, habiendo intersubjetividades, icómo es esta percepción? Percibimos un objeto $X$. Todos los sujetos tienen una posición espacial tal que ese mismo objeto es percibido desde diferentes ángulos, diferencia dada por la variedad de subjetividades perceptivas. La cuestión es: ¿cuál es la verdadera percepción?, o bien: si la percpeción es diferente en cada uno, entonces, ino es acaso mutilada, parcial y, por tanto, falsa? Merleau-Ponty afirma que una pura visión o la percepción dede un ángulo de una cosa es la percepción de una particularidad irreductible, virtualización de una totalidad y de cada una de las singularidades o perfiles de la cosa.

Ahora, dadas varias percepciones de cada perfil que expresa todas las posibilidades, Merleau-Ponty niega que todas las percepciones sean verdaderas o todas sean falsas; niega, también, que una sea la verdadera y las restantes falsas; rechaza, asimismo, que cada una sea verdadera de alguna manera; descarta la posibilidad de una verdad en sí vinculada a la noción de nóumeno kantiano, pero, al mismo tiempo dice que debe haber la verdad (desde luego, no en sentido absoluto), es decir, rechaza también el cuestionamiento hiperrelativista y protagórico de que no hay necesidad de la verdad. ¿Qué nos queda? El nivel de la comunicación, el campo del lenguaje.

Es por el lenguaje que se establece un consenso, una comunidad, respetando cada percepción, esto es, la percepción misma, el hecho de percibir; el lenguaje es silencioso, en el sentido de que es indirecto -tal como dice Levinas-de que es interior; ni la palabra es previa al pensamiento, ni el pensamiento precede a la palabra: irrumpen dinámicamente al unísono, nacen de las profundidades del ser movedizo. Así como lo invisible está como ausencia en nuestro campo visual, hablamos internamente más de lo que "decimos"; en un "mundo compartido" lo único que puede tener un sentido absoluto es el lenguaje.

La palabra tiene sentido sin que exista la necesidad de que agote el significado o los significados, simplemente "hay que ponerse de acuerdo", además, nuestro cuerpo, nuestra vida, es movimiento, como veíamos, y ése es nuestro sentido; de ahí que las palabras fluyan en nosotros pues, al fin seres de la contradicción, ambiguos e incoincidentes con nosotros mismos, 
NOTAS

debemos hablar por nuestro carácter temporal, porque somos tiempo.

La presencia del lenguaje es potencia y ensanchamiento, intensidad y expansión. Igualmente para Levinas, la función del lenguaje es la misma, siendo que el lenguaje separa, esto es, posibilita la trascendencia:

en su función de expresión, el lenguaje mantiene precisamente al otro al que se dirige, a quien interpela o invoca. (...) Pero por esto el lenguaje instaura una relación irreductible a la relación sujetoobjeto: la revelación del Otro. ${ }^{6}$

Y también:

La objetividad del objeto y su significación provienen del lenguaje (...) propone lenguaje un mundo. El mundo precisamente como propuesto, como expresión, tiene un sentido, pero no es nunca por esta misma razón, original de él. Para una significación, darse liebhaft, agotar su ser en una aparición exhaustiva, en un absurdo. ${ }^{7}$

Es así que para ambos filósofos la significación está presente en la idea de infinito, rompiendo la totalización y

${ }^{6}$ E. Levinas, Totalidad e infinito, 1977, Salamanca, Ed. Sígueme, p. 96.

${ }_{7}^{7}$ lbid., p. 118, Cfr. también para toda esta relación entre Levinas y Merleau-Ponty, de Levinas, Humanismo del otro hombre, pp. 29-33 y mi ensayo La alteridad y el problema del Otro, cap. II, pp. 6-10. la concepción de sustancias. Éstas son atributos o modalidades de la percepción (vgr. la ciencia); la significación dada en nuestra relación con el mundo no es, así, a priori, sino contemporánea. La significación se da en el diálogo (déparler), no precede ni sucede: palabra y significación irrumpen simultáneamente y así el sentido es una virtualización de infinitos sentidos.

\section{Cuerpo y subjetividad}

La relación viva y primigenia con el mundo está dada por el cuerpo, ese cuerpo que configura un espacio previo. El espacio objetivo es derivado del espacio estructurado por mi cuerpo: Merleau-Ponty parte de los análisis de Koffka, pero trasciende críticamente las explicaciones de la psicología estructural. La Gestalt afirma que percibir es percibir estructuras y no partículas atómicas sensibles; a partir de esta novedad podemos así pensar que habitamos un mundo estructural. Pero el peligro del estructuralismo (y la Gestalt) es que, aún así, se forma una sustancia privilegiada del mundo, se forma un campo definido, explicativo, definitivo.

Merleau-Ponty rebasa las consideraciones gestaltistas partiendo de ellas, sin negarlas, sino reelaborándolas. La espacialidad se da única, por así decirlo; la diferencia entre espacios es una concepción totalizante (empirsta o intelectualista, lo mismo 
da) que surge de concebir al cuerpo como objeto; estos dos espacios, a saber, el espacio corpóreo y el espacio exterior forman un sistema práctico, que no debería ser racionalizado:

Pero, al mismo tiempo, este espacio inteligible no es derivado del espacio orientado, no es más que la explicitación del mismo, y, arrancado de esta raíz, no tiene ningún sentido en absoluto, tanto es así que el espacio homogéneo no puede expresar al sentido del espacio orientado más que por haberlo recibido de él. ${ }^{8}$

El cuerpo debe ser considerado, entonces, espacio universal, puesto que la configuración de la exterioridad se da por mi espacio corporal. Sin mi cuerpo no habría espacialidad. Merleau-Ponty recurre a ejemplos patológicos para explicar esta cuestión de la corporalidad como el mundo mismo, para recalcar que nuestro cuerpo no está como espectador de un escenario colocado frente a él, que serían el mundo y los otros. En los "normales" todo acto es una situación experiencial ingenua, dotada de una signficación "sintetizada" por el sujeto sin que exista un análisis conceptual del acto en su totalidad. Todo movimiento corporal es un movimiento del sistema sujetomundo, de ahí que no se muevan partes

\footnotetext{
${ }^{8}$ M. Merleau-Ponty, Fenomenología de la percepción, 1985, México, Ed. Planeta, p. 119.
}

objetivas, sino potencias fenomenales, sentidos y signficaciones libres; la anticipación y la virtualidad son justamente la expresión de la riqueza de un cuerpo no objetivo. Cuando miramos, anticipamos una experiencia tactil, la que es virtualizada; luego, al ver, tocamos. En ciertos casos de enfermos esto no se presenta, pero en la mayoría de los movimientos concretos, éstos son una expresión de la potencia de un mundo particular, el enfermo confirma la cuestión porque para él, que es anormal, su cuerpo sí es un objeto, hace de su cuerpo un puro espacio objetivo, y hay que señalar la afirmación categórica que hace MerleauPonty en el sentido de que "no puede deducirse lo normal de lo patológico".. Toda suplencia, suplencia es, artificio; no es que en el no patológico exista una "naturalidad" debida al hábito que sintetiza y abrevia, sino que él, simple y sencillamente, percibe de manera normal. La diferencia fundamental es la siguiente: el cuerpo es la representación de las posibilidades del sujeto, cada movimiento corporal expresa virtualidades, interrelación entre sensaciones. En el caso patológico, en que el cuerpo es un objeto, todo movimiento es actual, está cerrado en sí mismo y su significación remite a una correspondencia unívoca y estática. Así pues, los signos del cuerpo no deben permanecer anclados a sí mismos, circunscritos en su en sí, sino

\footnotetext{
${ }^{9}$ Ibid, p. 124.
} 
NOTAS

que deben significar a través del mundo, y mi cuerpo y la percepción constituyen una totalidad armónica y expresiva. Aquí entra nuevamente la subjetividad, que aparece gracias al movimiento abstracto, de reflexión, introduciendo, al mismo tiempo, sobrepasando a la actualidad, lo virtual propio de lo humano.

Cuando el mundo es puramente actual, objetivo, el ser es esa plenitud detenida, fija y ya estructurada; cuando, por el contrario, el mundo significa a partir de posibilidades de movimientos, el ser es dinámico y cambiante, y enriquece las experiencias. De ahí que nuestros sentidos no se cierren en sí mismos, limitados a su objetos respectivos; Merleau-Ponty es claro al afirmar que un sentido es un estilo, una "variación" o una "manera" particular de ofrecerse y de acoplarse al mundo. Es por ello que la inducción es, para Merleau-Ponty el "veneno de la filosofía", ya que la explicación de los hechos no está dada para que la descubramos a posteriori; es inventada, y la invención dista mucho de ser inducción.

Para la Gestalt la conciencia se convierte a su vez en otro objeto, totalidad que no puede deshacerse en sus partes. Por tanto, hay que "dignificar" a la conciencia, revelando su peculiaridad irreductible a la cantidad. MerleauPonty es una especie de puente o de anillo de conjunción entre el estructuralismo y la fenomenología husserliana; busca las esencias, es cierto, pero no abandona una consideración de im- portancia para la inducción; en efecto, a propósito de Husserl, MerleauPonty afirma que la inducción unida al conocimiento reflexivo nos da lo que Husserl denomina psicología eidética. Continúa Merleau-Ponty en su interpretación:

mientras no hayamos dado, por una reflexión sobre nuestra experiencia de la imagen, sobre nuestra experiencia de la percepción, un sentido coherente y valedero a esas nociones, no sabremos nosostros mismos lo que quiera decir y lo que prueban nuestras experiencias sobre la percepción o sobre la imagen. ${ }^{10}$

Así, para Merleau-Ponty, virtualizar no es otra cosa que inventar presencias a partir de faltas, de ausencias. El movimiento abstracto tiene una función simbólica que ordena en un sistema a los datos sensibles, representativo de la conciencia y que nos remite a su vez a lo intencional: germen de la fenomenología: "si un ser es conciencia, es preciso que no sea más que un tejido de intenciones." ${ }^{11}$

El cuerpo es una variación del mundo, una expresión del sistema, simplemente. El mundo es, en primera instancia, algo que vivimos y que sentimos, su origen es la sensibilidad, la

${ }^{10}$ M. Merleau-Ponty, La fenomenologia y las ciencias del hombre, 1969, Buenos Aires, Ed. Nova, p. 42.

${ }^{11}$ M. Merleau-Ponty, Fenomenologia de la percepcion, p. 138. 
ambigüedad prístina que comienza ya a inventar, a inventar sentidos. La subjetividad y el cuerpo son mi acceso al mundo, pues ni la alteridad ni el universo están fuera de mí; mi acceso al mundo es "imperfecto" porque ambigua es mi relación con mi mundo, así es su esencia. Tratar de fijar una sustancia objetiva del mundo es una creación falsa porque el cuerpo está fuera de la oposición radial, de las dicotomías. El cuerpo es templo de la reflexión; a partir de esta idea, Merleau-Ponty interpreta tanto a la conciencia como al mundo, y esta interpretación bilateral es una de las características esenciales del sistema filosófrico merleaupontiano.

En resumen, la filosofía de Maurice Merleau-Ponty se propone resucitar, por medio de la genuina reflexión filosófica, al cosmos humano en base a dos cuestiones fundamentales:

1) ¿De qué manera tenemos acceso al mundo, cómo es que se nos muestran sus signos? y

2) ¿Quién hace tal ofrecimiento?

La primera cuestión es respondida con la teoría de la subjetividad, el comportamiento e, igualmente, con las consideraciones acerca de la percepción. La segunda tiene su respuesta en la cuestión del lenguaje, principalmente. 
NOTAS

SADAM REY, SADAM EN

COLONA*

Ghessan Salame**

D estruí, en 1979, el PC iraquí y diezmé a sus dirigentes.

Condené, como nadie lo hizo, la invasión soviética a Afganistán y suministré armas a los mujaidines.

Hice volver por la fuerza a Egipto dentro de la familia árabe, después de años de ostracismo debidos a los acuerdos de Campo David.

Hice la paz con vuestro amigo el Sha en 1975 y la guerra a vuestro enemigo el Ayatollah a partir de 1980.

Siempre estuve a favor de los precios petroleros bajos y lo he probado, desde 1973 hasta nuestros días.

Expulsé a Abu Nidal de Bagdad para apartarme del terrorismo y bajé el tono con Israel durante todos los años de guerra con Irán.

Sostuve firmemente al rey Hussein de Jordania, vuestro hombre y aliado.

Firmé dos acuerdos de no-agresión (en 1980 y de nuevo en 1989) con vuestro protegido saudí y en diez años no hice nada para perturbar su seguridad.

Hice todo esto porque pensé que podía ser vuestro mejor amigo en la

región; más aceptable que el Sha para mi población, menos minoritario que Assad, no otaniano como los turcos, más poderoso que los saudíes, menos aislado que Israel. Esto es lo que soy. Creí que lo habíais comprendido cuando se organizó conjuntamente, en la primavera de 1988, el aplastamiento de Irán, yo rechazándolo de la península de Fao y ustedes castigándolo en el mar: yo enviando mis misiles sobre Teherán y ustedes, manipulando subrepticiamente las resoluciones en la ONU. A Irán lo contuvimos juntos, y os perdoné vuestro desliz del Irangate.

Pero después que esta guerra terminó y que el Ayatollah murió, la Voice of America me compara con Ceaucescu. US News me llama en su portada 'el hombre más peligroso de la tierra', y es suficiente que yo importe una pieza de cañón o un pequeño encendedor de reactor para que me encuentre con vuestros servicios especiales y vuestros periodistas en la puerta, pisándome los talones. Vuestra complacencia bancaria se agotó y

* Tomado de Libération. Traducción de Nilda Ibarguren.

${ }^{* *}$ Director de investigaciones en el CNRS y profesor en el IEP. 
perseguís a los bancos que todavía me prestan, como la filial de la BNL italiana de Atlanta. A decir verdad, una vez contenido Irán ya no habéis tenido necesidad de mí; vuestro viejo aliado israelí os excita contra mí; vosotros incitáis a los kuwaities a privarme de su ayuda. Entonces os voy a dar una lección, y a ver qué hacéis."

No es que la Historia pueda reducirse a una historia de amor, pero en el conflicto irako-americano, tal vez de eso se trate. Meses antes de la invasión a Kuwait, Sadam se sentía un amante rechazado, abandonado, condenado incluso. De donde provienen una serie de endechas, destiladas a sus visitantes americanos y que se han resumido y reunido más arriba.

Pero hasta que la ONU no nos hiciera saber, en medio de la noche, que la guerra había comenzado, se podía pensar que ésta era evitable. Queda por saber por qué no lo fue.

Faltaba, desde luego, que Sadam se decidiera a retirarse de Kuwait. No lo hizo. No por quedarse con Kuwait, o sus riquezas. No porque el nacionalismo árabe, estilo prusiano trasnochado, lo cegara. No porque los palestinos no hubieran obtenido nada en cinco meses de tratativas. Si Sadam no retiró sus tropas fue porque pensó que, por más que hiciera, los americanos querían su pellejo. Más valía por ello intentar lo imposible, cambiar radicalmente $\mathrm{o}$, al menos, y ya que Washington había decidido su fin, encontrar una salida.
El sentir que se quería acabar con él es una idea de Sadam que precedió a Kuwait. Toda la conversación sostenida con la embajadora americana, April Glaspie, lo confirma.

Ya abierta la crisis, Sadam comprende que, a los ojos de Bush, él representaba a "Hitler, peor incluso que Hitler", una condena que cerraba todas las vías de salida. Si Sadam era Hitler, Washington se comprometía a liberar al mundo de su presencia. Sadam lo entendió como una condena sin vuelta. No estaba errado al pensarlo. Al comparar al señor de Bagdad con el Führer, quedaba vedado $\mathrm{Mu}$ nich, y en lo sucesivo todo acuerdo podía parecerlo. $\mathrm{Y}$ por lo tanto, se impedía todo acuerdo.

El rechazo americano de las propuestas francesas en la ONU, $\tan$ poco apremiantes para los americanos, acabó seguramente por convencer a Sadam de que no se le quería dejar espacio para ninguna puerta de salida. Norteamericanos cercanos a la administración nos lo repetían desde mediados de octubre, por lo menos. Su papel había terminado para Washington. Él era el testigo molesto de una época pasada, cuando se logró seapararlo de Moscú y luego lanzarlo contra el Ayatollah.

Por esto, hay en la trayectoria de Sadam un verdadero sentido trágico. Siendo un huérfano de padre, se había labrado un nombre, si no un apellido, a costa de mil aventuras, de mil golpes de mano, abusos de autoridad, golpes 
NOTAS

de Estado, de mil fechorías. Desde 1979, había eliminado sin ceremonias inútiles a su padre político, el viejo mariscal Bakr, y lo había remplazado en la conducción del Estado. Faltaba ahora que pudiera gobernar. Afectado por la hybris de los mal nacidos convertidos en potentados, tuvo el realismo de volverse útil a Occidente al día siguiente de la caída del Sha. Para su desgracia, y para la de su pueblo, sacó muy rápidamente de ello la intuición de un gran destino para sí, para su país, para los árabes.

Pero otros veían en él al instrumento expletivo antes que al jefe irremplazable. Los norteamericanos se acomodaban mal a sus ambiciones, la URSS de Gorbachov no lo quería, Francia le recordaba sus retrasos en los pagos, Gran Bretaña lo condenaba después del asunto Bazoft. En el nuevo contexto internacional, él resultaba a la vez arcaico y molesto. Buscó explicarse, pero los dictadores acorralados raramente son escuchados. Magro consuelo, presidió dos o tres cumbres árabes donde hizo una demostración de su fuerza, y de su serenidad. Sus pares lo aplaudieron soñando con su caída. Su "fuerza tranquila" ya no tranquilizaba a nadie.

Entonces, seguro de sus regimientos, y consciente de su destino, marchó hacia Kuwait la muerte, más como Edipo resignado y sereno que como musulmán creyente y fatalista. Y para los Sadam de esta clase, los pueblos cuentan muy poco. Arrastró al suyo, y tam- bién a otros pueblos, no porque se hubiera vuelto súbitamente carismáti$c o$, sino porque hablaba, al fin, un lenguje comprendido. No era un Nasser, con el cual había identificación por más que se dijera, sino un jefe que lograba, si no vencer, convencer. De la arrogancia de las gentes del Golfo, del poder inigualado de Israel y, especialmente, de la duplicidad norteamericana, él estaba convencido, porque ya era víctima de esos "males".

Sadam, el táctico hábil, el realista, el astuto, se ha transformado en Sadam el héroe de la tragedia; todavía astuto en la elección de los arbitrios cotidianos pero resignado ya en el desenlace final. Ya no intentó nada, liberó a los rehenes, concentró sus fuerzas y esperó los primeros obuses norteamericanos. Luego, juega a ganar tiempo para sí y a fatigar a sus enemigos, mezcla de la paciencia del hombre de las estepas y de la astucia del levantino. Si muere, es como héroe. Si sobrevive, es para ser un presidente "normalizado". Nada indica que esté dispuesto a esta nueva mutación.

Hasta aquí, Sadam se había mostrado como un táctico hábil, más bien útil a la gran estrategia regional de los Estados Unidos. El hundimiento de sus cálculos eleva paradójicamente a este hijo sin padre a la dimensión de un héroe de la tragedia árabe. 
NOTAS

\section{PORQUÉ LOS MAGREBÍES DE FRANCIA SE OPONEN A LA GUERRA DEL GOLFO...* Driss el Yazami**}

$\mathbf{E}_{1}$

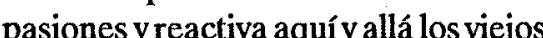
clichés, las fórmulas hechas, y somos conminados a tomar inmediatamente posición, sin matices ni estados de ánimo. En esta perspectiva, cada uno debe reintegrarse a su tribu, su "comunidad" de origen y declararse a favor de ella, callando críticas e interrogantes.

Este requerimiento de residencia comunitaria ha funcionado tanto mejor cuanto que, desde el comienzo de la guerra, hemos visto surgir por todas partes "llamados a la calma" lanzados a las comunidades supuestamente dispuestas a pelear, mientras otros se apresuraban a ir a tomar el pulso de ciertas mezquitas a la espera de no sé qué prédica encendida. La sospecha en lo relativo a la fidelidad y a la lealtad de las poblaciones de origen extranjero y particularmente magrebí, estaba aún más fortalecida porque tales llamados emanaban de responsables "co- munitarios" que deben saber, se dice, de qué hablan.

Sea lo que fuere, la primera lección de esta crisis es que las poblaciones residentes en Francia han reaccionado, en su inmensa mayoría, serenamente, cualquiera que haya sido su sentimiento profundo. Muy sencillamente porque saben dónde está su interés y quieren preservar ese espacio democrático cuyos méritos y beneficios conocen, aun cuando sea de manera confusa. Esta sana reacción dice mucho sobre la madurez de tales poblaciones y su grado de integración a esta sociedad y revela la adhesión que prestan a sus valores y a sus normas. Porque conocen por experiencia el estado de deterioro de su sociedad de origen y su déficit democrático permanente los magrebíes residentes en Francia aprecian en su justo valor el beneficio de la paz y de la libertad que asegura una sociedad democrática.

Por ello, el verdadero peligro que

\footnotetext{
"Tomado de Le nouvel observateur. Traducción de Nilda Ibarguren.

"* Miembro del comité central de la Liga de los Derechos del Hombre, coautor del llamado "Paz, democracia y deșarrollo".
} 
NOTAS

nos acecha no es el de esta confusa "guerra de las comunidades", sino la zanja que puede abrirse entre los pueblos del Norte y los de allende el Mediterráneo. Conocemos muy bien los problemas que horadan al mundo árabe, y sabemos que esta guerra no los resolverá

La invasión de Kuwait por el régimen iraquí no es admisible, y cuando exigimos una solución al problema palestino que hemos denunciado, lo hacemos en nombre de los principios, y en nombre de los principios muchos de nosotros hemos aprobado las medidas de embargo.

Teníamos demasiado presente en la mente esas espantosas imágenes de los kurdos de Halabja y el recuerdo de los relatos de nuestros amigos iraquíes torturados para creer un solo instante en Sadam Hussein y todavía menos para alistarnos en sus filas. Pero a la vez no podíamos olvidar a los niños de la Intifada y las indignaciones selectivas de la administración americana para creer en el advenimiento milagroso de una nueva era para la humanidad donde el derecho se impondría en todo el planeta a las lógicas del interés.

No podíamos olvidar a los jóvenes de Argel o de Fez segados en la flor de la edad, o a las mujeres emparedadas vivas de Arabia Saudita. No podíamos reconocernos en esa imagen caricaturesca del "camino árabe" que nos era remitida por las televisiones demasiado presionadas y que anulaban la com- plejidad de las aspiraciones y de los problemas de estos pueblos.

Sabíamos, por haber estado muy cerca de ellos, que, de Rabat a Kuwait justamente, las secciones de Amnistía Internacional trataban de abrirse camino, las orgnizaciones de defensa de los derechos humanos eran cotidianamente blanco de la represión, los grupos de mujeres eran cada vez más numerosos, y que movimientos culturales vivaces daban testimonio del pluralismo del mundo árabe. Desde el corazón mismo del pensamiento islámico, intelectuales valientes sometían la historia y al patrimonio musulmán a una relectura crítica y fecunda. Los elementos de un nuevo pensamiento democrático árabe se asentaban penosamente, y asistíamos a una lenta pero real impregación de esas sociedades por los ideales de democracia, de laicismo y de igualdad de sexos. Frente al polo constituido por los islamistas, un polo laico estaba en vías de cristalizar, a pesar de la represión de todos los regímenes árabes. "Moderados" o "radicales", los poderes establecidos rechazaban esta disidencia, coqueteaban con los integrismos y no veían en sus pueblos que exigían la ciudadanía más que eternos menores de edad cuya fidelidad era preciso ganar aun cuando vivieran en el extranjero.

La guerra y sus consecuencias deben abordarse con toda esta memoria y teniendo en cuenta esta complejidad. Si es justo exigir la restauración de la soberanía kuwaitíy el derecho de 
los israelíes a fronteras seguras y reconocidas, una verdadera política árabe de Francia y de Europa exige desde ahora otras ambiciones que deben ser enunciadas e ilustradas a pesar del fracaso de las bombas.

Es ahora cuando debemos reafirmar el derecho de los palestinos a una patria y es con el único representante elegido, la OLP, con quien debemos discutir. Es ahora cuando hay que hablar con Arafat y no ceder a las presiones en torno a su representatividad pues, al hablarle, se lanza la verdadera señal de esperanza a los palestinos y a los árabes y se ilustra lo que puede ser una innovadora concepción del derecho internacional.

Es ahora cuando tenemos que decir que la democracia es para los países árabes el único horizonte posible y cuando debemos asegurar a sus pueblos nuestra solidaridad en ese combate. Es hoy cuando nos toca proclamar que, de la misma manera que no aceptamos que una dictadura controle una parte significativa de las riquezas petroleras, juzgamos también inadmisible que algunas familias se arroguen, sin ninguna legitimidad, ese derecho.

El lenguaje de las armas no puede ser el único que tengamos con los pueblos de estos países; la presencia en la coalición de regímenes árabes ilegítimos y deshonrados no puede dispensarnos de buscar otro. La política y la democracia deben, aquí y ahora, retomar sus derechos y enunciar clara- mente sus fines. De no hacerlo, se está expuesto al debilitamiento y tal vez a la desaparición de todos los polos democráticos, que son los únicos interlocutores del futuro. 


\section{RESEÑAS}

LEE SMITH, Damas tiernas y hermosas, 1990, Barcelona, Ediciones Destino, 432 p. ISBN 84-233-1924-5.

¿Cómo ha cambiado el siglo XX en Norteamérica? De muchas maneras. Sin lugar a dudas, en forma perceptiblemente vertiginosa. Pero también a otros ritmos. No cambió de igual manera en Nueva York o en San Francisco que en las montañas rocallosas. Aún en el país que le ha marcado la hora al siglo XX los cambios han presentado diversos ritmos. Y algunos de ellos son comparables, por su lentitud, a los cambios en Tinguindín o en Cuzco. Por supuesto que en estos lugares en algún momento llegaron la electricidad, el automóvil, la radio, el teléfono, pero no en todos ellos hicieron acto de presencia a la misma velocidad. Vistos desde afuera y, sobre todo, desde el presente los cambios parecen vertiginosos. Desde adentro y a su ritmo son, evidentemente, más pausados. Así ocurrió en las montañas del Sur en Norteamérica. Así le ocurrió a Ivy Rowe en el período que va de 1900 a 1975. Es decir, en el lapso en el cual del uso del caballo que servía, entre otras cosas, para raptar doncellas, se pasó a la lucha por los derechos civiles, que se equipara a la lucha por los derechos humanos en otras partes del planeta.

Damas tiernas y hermosas de Lee Smith es la espléndida microhistoria literaria de una niña que a los diez años empieza a escribir cartas a inciertos destinatarios sobre una realidad norteamericana ignorada $o$, al memos, poco conocida. En esas cartas cuenta su infancia en las montañas del Sur y, más tarde, su peculiar y, al mismo tiempo, común adolescencia al lado de una madre de otras épocas. También cuenta en esas cartas, cada vez con memos faltas de ortografía y una voz poco a poco más propia, la vida de una madre soltera de entonces, la primera Gran Guerra para una joven norteamericana de las montañas del Sur, el matrimonio, la pérdida de la juventud, el amor fuera del matrimono y su progresivo envejecimiento. Pese a la tradición, Ivy cambia y, más mal que bien, se adapta a su vertiginoso siglo. De esta manera, su voz también cambia, y hace frente a los cambios, de acuerdo con sus propias necesidades. Así, al principio 


\title{
RESEÑAS
}

escuchamos una voz coloquial y tierna, que poco a poco se endurece, sin dejar de lado la ternura, la impotencia, la melancolía, el amor. Por esto, el relato epistolar de Lee Smith se sitúa perfectamente entre el relato de lo que fue esa agreste Norteamérica y la capacidad imaginativa que hace del relato una novela.

Tal vez desde Faulkner no se presentaba en la narrativa norteamericana un escritor tan notable como Lee Smith.

\author{
JULIÁN MEZA \\ Departamento Académico de \\ Estudios Generales, ITAM.
}


RESEÑAS

TERESA AVELEYRA-SADOWSKA, Hasta la tercera y cuarta generación, 1990, México, Joaquín Mortiz, 255 p. ISBN 968-27-0395-6.

Clara Da Silveira se enfrenta en su cama a la muerte y a la vida. Nació en la Colonia Rọma, y ni siquiera mereció el calificativo de sietemesina. Mientras duró la gravedad de su madre parturienta fue alimentada a cuentagotas con leche maternizada y caldo de legumbres.

Palabras más, palabras menos, así empieza Aveleyra-Sadowska su novela Hasta la tercera y cuarta generación. En ella entreteje retratos de personajes y familias y ocupa un lugar la evolución de la Ciudad de México, de los gustos y costumbres de sus habitantes.

Clara, la niña y Clarita, la mamá son los personajes. Con mucho humor, la narradora describe a su bebé, Clara, una vez que se ha afianzado a la vida: "las facciones graciosas -nada más- se perdían entre protuberancias carnosas en mejillas y barba; la papada era de vieja glotona; los pechos, de nodriza; el vientre, de Buda; los muslos, de pavo de Navidad..."

Alegre por vocación, Clara era tan sensible a los ruidos, a los malos olores, a las pesadillas infantiles, como aficionada a la naturaleza, al sol, a las flores, al arroz con leche, a la música, a recitar, a las travesuras, a jugar. Antes de entrar en parrulitos prácticamente sabía leer. Por parlanchina y juguetona su padre solía repetirle: "iClara, hijita, no hables tanto que nos aturdes!"

México, diciembre de 1924: "Clara tomó plena conciencia de la singularidad de la temporada. Ésta se inició con expediciones familiares a la 'Casa Boker' -donde había la mejor pirotecnia alemana- y a la plaza de La Merced. El aprovisionamiento era mayúsculo y repetido, pues se trataba de celebrar, con cien o más invitados, las nueve noches de las Posadas y -en familia, sólo en familia y en torno al Nacimiento- la fiesta de Navidad."

La imagen del padre: un ser amable e insociable, médico de ricos para poder serlo de pobres, generalmente serio y siempre bondadoso.

Almidón en las sábanas, colonia Jean Marie Farina, baños de tina, boiler de leña, director espiritual, nana, Congregación Mariana, Caballeros de Colón, Madres Católicas, Liga Mexicana de la Decencia, Catecismo del padre Ripalda, 


\section{RESEÑAS}

recortes de caramelo comprados por kilo en Larín, el Buick de siete asientos, teléfonos Ericcson y Mexicana, las tiendas elegantes: Maria Pavignani, La femme chic, Kamchatka y La Pompadour, los baños turcos del Hotel Régis sirven de marco nostálgico, divertido y equilibrado, a reflexiones como esta: "...ella siguió sintiendo que el primero y quizá el único mandato divino era 'Honrarás a tu padre y madre' ...sólo muchos años más tarde llegaría a pensar que ...faltó la justa contrapartida: 'Respetarás a tu hijo'."

Clara describe su casa como "una verdadera casbah: una casa grande y fortificada, cómoda e higiénica, pero fea, complicada y extravagante como esas colchas formadas de parches cosidos entre sí. Además, su sobrepoblación de antiguos cristos, santas y santos mártires, le daba aire de iglesia de novenario de penitencia; y la multiplicación de cerrojos, pasadores, pestillos, candados y trancas producía el escalofrío que debe de sentirse en las prisiones..."

En el cine Balmori, entonces en Avenida Jalisco, había matinés dominicales a los que no podían faltar Clara y sus hermanos. Los besos en las caricaturas, la literatura médica del padre, los fragmentos de las conversaciones de los mayores fueron para la niña -como para muchas de sus semejantes, antes y después, ayer y hoy a pesar de la televisión- fuente primaria de "educación" sexual, la forma de "perder la inocencia". Los padres, alarmados por los conocimientos de su hija la mandaron con el confesor, que se encargó de aterrarla con el sexto mandamiento, "ese misterioso 'No fornicarás" y, como consecuencia, "conoció, por primera vez, el terror que produce bascas, que aprieta las quijadas y hace doler, uno por uno, todos los dientes".

Primera Comunión. Vuelta a sentirse limpia. La persecución religiosa libera a Clara del terrible confesor y la conduce por corto tiempo al confesionario de un sacerdote comprensivo.

El tiempo pasa. Clara es inscrita en el Colegio Francés de la lejanísima Colonia del Valle. Nuevo hermano, muchas aventuras, inicio del oficio de escritora y primer enfrentamiento con su madre. Llegan los once años y descubre su condición de mujer.

La residencia de la familia paterna "tenía dos patios, varias cocheras, pesebres para el tronco de caballos, habitaciones suficientes para la servidumbre, y seis accesorias hacia la calle... El afrancesamiento reinante apenas si entró en aquella casa, que siguió la tradición de las antiguas mansiones mexicanas: patio principal de grandes losas de piedra; pozo con noria de malacate; arriates florecidos en torno;... escalera monumental de ida y vuelta hacia el alto corredor y las habitaciones de su familia..."

El abuelo, "de cepa liberal y adherido al positivismo de la época, miraba con indulgencia la beatería de sus hijas -'sustituto del matrimonio', decía... Permitió 


\section{RESEÑAS}

que a su casa entrara el periódico avanzado El Imparcial, pero no El diario del hogar, publicación dada a la mojigatería".

La familia materna, de origen "noble" y tapatío, tiene también su lugar en la historia. El amargado y cruel abuelo, que, sin embargo, fue capaz de entregarse a su familia y "dar a la esposa, aún joven y linda, ese poquito de ternura que no se le pudrió en la juventud", se ensañó particularmente con Clarita, su hija menor y madre de Clara. Clarita aprendió pronto a usar su privilegiada inteligencia natural para manipular al padre y, llegado el momento, "asumió con claridad su papel de seductora."

La fuerte y solitaria Clarita fue capaz de dejar a su anciano y rico padre cuando se enamoró de una joven de su edad. Clarita la seductora era temible al rechazar las pretensiones matrimoniales, hasta que Rafael, el doctor solterón, por los hechos más que por la edad, olvidó eso de que "al matrimonio sólo se entra como a una regadera de agua fría y le hizo la corte enviándole "ramos de violetas y primorosas cajas de fresas con crema."

"Rafael Da Silveira y Clarita Antuñano de los Ríos se casaron en la iglesia de Buen Tono, que entonces era iglesia de las bodas 'diferentes'."

Clara, la hija, vuelve a su casa cuando el cardiólogo la ha dado de alta y sigue con sus recuerdos: el colegio de monjas inglesas en donde estudiaría la secundaria hecha una mangani, las juveniles fantasías eróticas, los regalos y halagos paternos, las zarzuelas, las comedias blancas de las hermanas Blanch en el Ideal, los viajes en el vagón especial de Ferronales a Estados Unidos, la primera aventura en avión, el cinturón de culebra en el que el padre lleva sus centenarios de oro. Clara revive las manipulaciones de una madre castrante, ienvidiosa de su hija adolescente? En su ser retumban las terribles y frecuentes palabras maternas que reprueban la costumbre de leer: "No te basta con ser un marimacho que no sirve para nada en la casa, no te basta con no ser una mujer en tu hogar: ahora haces la víctima, para ponerme en mal con tu papá..."

Adolescente, es asaltada por toda clase de sentimientos contradictorios y despierta a la vida sin alguien que la guíe. Es conducida por libros sagrados y jesuitones, recomendados o no. Clara y su padre, cómplices. Clara obsesionada por la muerte, Clara adelgaza a pesar de los vasitos de Quina Laroche y las dosis diarias de Yodalactina Manuell, de Emulsión de Scott y de Fosselite B.

Tras ciento nueve páginas leídas de una sentada, Teresa da un respiro al lector. Luego llega al "Barrio de Metepec", a la fiesta de San Lorencito. Vida del sacerdote Cantera, en realidad nieto de su padre legal, hijo de su hermano, confesor-inquisidor de Clara, de ese desdichado "sacerdote a medias" cuya personalidad tenía tres facetas: "la belicosidad jesuítica, la solitareidad cartujana, y la propia insana inclinación hacia el sufrimiento propio y ajeno." 


\section{RESEÑAS}

Clara, la quinceañera humillada que no da su brazo a torcer, oye la opinión que tiene de ella su madre: "lo que pasa es que eres una cuerona, sí cuerona, de esas gentes que ni sienten agravios ni agradecen beneficios." Clara, obligada a permanecer en casa un año para descansar de la secundaria. Residente de "la línea Olinalá" -por aquello del nombre de su calle y de la línea Maginotpermanece oculta al mundo en una casa cuya puerta de fierro ha sido construida por Gabelich.

Las esperanzas familiares: que Clara estudiara medicina, pero ella se inscribió en Letras y en Filosofía en el local de Mascarones. Estudiaba y disfrutaba de su libertad en los camiones Roma Mérida y San Rafael. Un viejo y querido profesor y tres jóvenes eran sus cuatro enamorados. Último día en el siglo: enmedio de una tormenta capitalina que provoca un apagón la nueva postulante es dejada por su familia en su convento-cárcel de la calle Murillo en Mixcoac.

Otro paréntesis nos lleva a Italia y nos regresa a México con el padre Ambrosio y la historia de su madre, fundadora de una orden religiosa, hija de un diplomático italiano y embajador frustado en tiempos de Don Porfirio, viuda de un aguerrido capitán, cuyo décimo hijo es el sacerdote.

Clara en el convento es la número 49 , la vestal de primera clase, pero tiene que disfrutar la soledad en Dios en compañía de cinco desconocidas, azotarse nalgas y muslos en vez de la espalda porque en las congregaciones modernas no se usa una disciplina que puede dañar los pulmones.

En este ambiente de sufrimientos y alegrías, resurgió, más poderosa que nunca, la primera vocación de Clara: la alegría.

"La ceremonia de toma de hábito de Clara Da Silveira fue espectacular, gracias a que Doña Clarita... puso el mayor y más logrado empeño en mostrar, dentro y fuera del convento: ante las Oblatas, los numerosos parientes y amigos y, sobre todo, ante sí misma, cuán preciosa era la prenda de la cual se había desprendido por amor a Dios."

Después Clara se vuelve una coqueta novicia a la que pronto le caen responsabilidades y autoridad. Clara es la hermana escritora que hace sus primeros votos, temporales en voz alta y perpetuos en su fuero interno. Clara, madre maestra, sigue la regla paterna: "suavidad en la forma; firmeza en el fondo".

Clara y el padre Ambrosio: intercambio de ideas, desayunos, dudas, penas, gratitudes, traducción privada. Clara enferma gravemente. Su médico-papá prescribe paseos al aire libre, salidas del convento. Clara descubre las manipulaciones del padre Ambrosio. Clara y el sacerdote, enamorados. Clara separada de su convento por el clérigo enfurecido. Clara enviada a una casa de provincia. Clara en el campo. Clara huérfana.

Escuela, maestra, chofer, aventurera. La madre Clara enviada de vuelta a 


\title{
RESEÑAS
}

casa descubre que la ciudad también ha cambiado en el transcurso de seis años: los supermercados y Sears, la tienda gringa que hace furor.

Primer día mundano. Euforia y exaltación. Dudas e incertidumbres. Libertad que era a veces un camino "ancho y despejado, pero, la mayor parte del tiempo la asustaba como un vacío, como un abismo." iTraductora en la UNES$\mathrm{CO}$ o vendedora en Sears? El padre Bordas, que confiesa haberle visto "cara de fémina inquieta y andariega", le pide que tenga cuidado, no vaya a ser que le suceda lo que a las doncellas del Quijote, "que llegaban a los ochenta años con toda su virginidad a cuestas", y le ofrece ayuda para una beca en Francia, en donde lo primero que aprende es la delicia de los zapatos bajos y cómodos, Clara muchos años después escribe cerca del final...

\author{
LUZ MARÍA SILVA \\ Departamento Académico \\ de Estudios Generales, ITAM.
}




\title{
RESEÑAS
}

ZAMIATINE, Nous autres, 1990, París, Gallimard, 233 p. ISBN 2-07028648-7.

Después de Butler, Zamiatin. Antes de Huxley y de Orwell, Zamiatin. Con sus diferencias, pero también con sus semejanzas. A Butler le inquietaba el rudo ritmo del progreso técnico y en particular el de los relojes. A los otros tres también les preocupaba la técnica, pero antes que a Huxley y a Orwell a Zamiatin le angustian los sistemas totalitarios. Así, Nosotros es la primera novela sobre la utopía totalitaria del Siglo XX. Reeditada en francés en 1971, ¿ ipor qué volver a editarla en 1990? En 1971 tenía sentido, se pensará, porque la realidad totalitaria era evidente. ¿Y en 1990? Además de que nunca, ninguna sociedad estará a salvo de la amenaza totalitaria, Nosotros de Zamiatin posee un valor intrínseco desde el punto de vista literario que tal vez ni Un mundo feliz ni 1984 tienen.

Tras la perestroika, la insurrección rumana y la caída del muro de Berlín se puede creer que la amenaza totalitaria ha sido definitavamente conjurada. Me parece un error esta creencia. Ninguna sociedad, decía Jaspers, por culta y civilizada que sea, está a salvo del peligro totalitario. Recordar los futuros horrores que ya ocurrieron no está por demás. Disfrutar, hasta donde el horror no lo impide, de la prosa de Zamiatin es un gozo al cual difícilmente se puede renunciar.

Escrita en 1920, Nosotros fue y seguirá siendo una joya novelística de la literatura rusa. No sólo, evidentemente, por su tema, sino, sobre todo, por su estilo, por un estilo que recuerda a sus grandes maestros y traza el porvenir a sus grandes herederos, de Bítov a Ierofiev.

Tal vez un editor austero quiera ahora publicar en español una obra que parecería, falsamente, ademas de inédita, tardía, pero que en realidad sigue siendo de enorme actualidad en un universo en el que supuestos órdenes mundiales amenazan, gracias a sus tecnologías, con la homogeneización a la escala del planeta. Como lo advierte Zamiatin, el totalitarismo no es un accidente; es una vocación -poderosamente auxiliada por la técnica, ahora.

\author{
JULIÁN MEZA \\ Depto. Estudios Generales, ITAM.
}


RESEÑAS

G. VATTIMO y otros, En torno a la posmodernidad, 1990, Barcelona, Anthropos, 175 p. ISBN 84-7658-234-X.

El volumen que nos ocupa es derivado de un simposio sobre el tema. Los trabajos colectivos, tan solicitados en el mundo de los negocios, por lo general no favorecen a los productos del ocio. Supongo que este libro se debe "vender bien", mas su contenido resulta algo pobretón. Creo que es buen indicador sí, de que los españoles están leyendo mucho, a juzgar por la enorme cantidad de citas a que remiten algunas ponencias.

Del conjunto encuentro particularmente interesantes dos trabajos, en primer lugar el de Vattimo, que esboza ciertas tesis más desarrolladas en su sugestivo ensayo El fin de la modernidad.

Contra la impugnación que sufre este término, consecuencia de su abuso, sostiene Vattimo que el concepto de "posmodernidad" tiene sentido, y está en relación con la sociedad telemática. La dificultad para tratarlo en buena parte es herencia de su antecedente necesario e implícito, pues entre la diversidad de nociones comprendidas bajo el fenómeno conocido como "modernidad", quizá el único criterio que permitiría un acuerdo sería el de considerarlo "la época en la que el hecho de ser moderno viene a ser un valor determinante".

En el devenir secular, desde el Quattrocento, momento en el que "oficialmente" arrancaría la era moderna, el culto por la novedad, originalmente privativa de lo artístico, va desbordando todos los ámbitos del quehacer humano. Con el consecuente sentido progresivo que adquiere la historia, lógicamente "tendrá más valor lo que es más 'avanzado' en el camino hacia la conclusión".

La filosofía de éste y el pasado siglos, con Nietzsche y Marx a la cabeza, ha criticado la idea de la historia con sentido único, poniendo de manifiesto el carácter ideológico de sus representaciones: las imágenes del pasado siempre son productos elaborados desde determinadas perspectivas.

"En la hipótesis que yo propongo, la modernidad deja de existir cuando -por múltiples razones- pues nos permite desaparece la posibilidad de seguir hablando de la historia como unidad unitaria."

La crisis del historicismo acarrea la de la idea de progreso. La crisis del colonialismo irá acompañada de la de un cierto ideal de hombre: ilustrados, positivistas, historicistas en última instancia por debajo de sus enfrentamientos 


\section{RESEÑAS}

tácitamente coincidían en que el sentido de la historia era correlativo a la realización de la forma del europeo contemporáneo.

Para el estado de la sociedad posmoderna, destaca Vattimo, será determinante la acción de los medios de comunicación-causantes de lo Lyotard denominara "disolución de los grandes relatos"- que vendrían a consumar la profecía nietzscheana según la cual el mundo real finalmente ha de acabar convertido en fábula. "Por una especie de perversión de la lógica interna, el mundo de los objetos mensurables y manipulables por la ciencia técnica (el mundo de lo real, según la metafísica) ha venido a ser el mundo de las mercaderías, de las imágenes, el mundo fantasmagórico de los medios de comunicación."

Creo que una de las contribuciones más significativas de Gianni Vattimo en aquel mencionado ensayo, consiste en el reparo de la vertiente positiva del nihilismo. Aquí, retoma esas meditaciones para señalar que Heidegger, internándose en la brecha abierta por las intuiciones más intempestivas de Nietzsche, pone al descubierto cómo la racionalidad cientificista para poder manipular todas las cosas, concebirá lo existente como sistema de causas y efectos e irá reduciendo todo a puras apariencias mensurables, sustituibles, hasta acabar por menoscabar "a este nivel incluso al hombre mismo, su interioridad, su historicidad..." Este reconocimiento delata la radical impostura del "principio de realidad" fraguado por la tecnología.

La irrefrenable profusión de los mass media aglutina un espectáculo abigarrado y disímbolo de imágenes del mundo. "En este relativo caos residen nuestras esperanzas de emancipación", estima Vattimo. Es decir, el desmoronamiento del sistema hegemónico, consecuencia de esta desordenada multiplicidad, no constituiría una pérdida de lamentar, sino posibilidades de revertir la institución de una cosmovisión subordinada por la ratio instrumental. Buena observación y mejor invitación, sin duda. (La constatación de un mundo desbaratado es circunstancia ideal para proponerse la creación de otro mejor, después de todo, todo cosmos humanamente imaginable exige como condición de posibilidad la precedencia de un caos.) Pero peligrosa de estimular un inoportuno optimismo a la orden del día si no se balancea con una exigencia de ascesis y trabajo. (A propósito, cuando Nietzsche proclama la necesidad de un orden "más allá del bien y del mal", no está proponiendo una licencia para el "todo vale", sino exhortando a una renovada lucha contra el filisteísmo.)

En el otro trabajo que me interesa destacar, Patxi Lanceros practica una inteligente lectura del texto de Walter Benjamin, "El carácter destructivo", que nos permite apreciar una interesante afinidad de las meditaciones de éste con "la chance del nihilismo" postulada por Vattimo.

Así como los renacentistas armaron para el medievo una imagen oscurantista 


\title{
RESEÑAS
}

-de la cual querían alejarse- inventando a la antigüedad otra idílica -para proponer un nostálgico retorno- y la Ilustración procedió análogamente estigmatizando al antiguo régimen, hoy asistimos a un fenómeno semejante: "Nunca la modernidad fue tan inequívocamente una como cuando ha tenido que oponer resistencia a la dispersión posmoderna." Mientras la posmodernidad opaca la luminaria moderna y denuncia el terrorismo idolátrico del progreso técnico; lo moderno pervive como reivindicación de seguridad ante la neobarbarie.

El debate posmoderno nos revela que los avatares de la cultura son múltiples y traumáticos. No ceden "ni al indolente monismo continuista, ni a la lógica binaria de la revolución, ni a la teleología trinitaria de la dialéctica". El actual momento de rupturas, como el Renacimiento o la modernidad, no puede reducirse a un proyecto homogéneo, situación por la que Lanceros defiende la denominación de "estrategias posmodernas".

En tanto que la modernidad en general ha pretendido especular la realidad, Nietzsche quiso pensar el pensamiento, evitando el optimismo de la representación que identifica la palabra con la cosa. Lanceros reconoce este legado intelectual en Benjamin, quien en el ensayo que trata, contra los dogmatismos propone la tarea antiinstitucional de la destrucción.

"El carácter destructivo no ve nada duradero. Pero por eso mismo ve caminos por todas partes" (W.B.). Destruye lo existente, pero no para quedarse ante la demolición, sino por la pluralidad de alternativas que se abren por entre los escombros. "No se trata de buscar para encontrar, sino para seguir buscando: invitación al perpetuo movimiento - comenta Lanceros- alerta frente al acomodo."

Foucault lo intuyó: "escapar realmente de Hegel supone apreciar exactamente lo que cuesta separarse de él." El pensamiento posmoderno sabe que en cada rendija mal vigilada puede acechar la seducción teleológica, la trampa hegeliana.

\author{
ALBERTO SAURET \\ Departamento Académico \\ de Estudios Generales, ITAM.
}




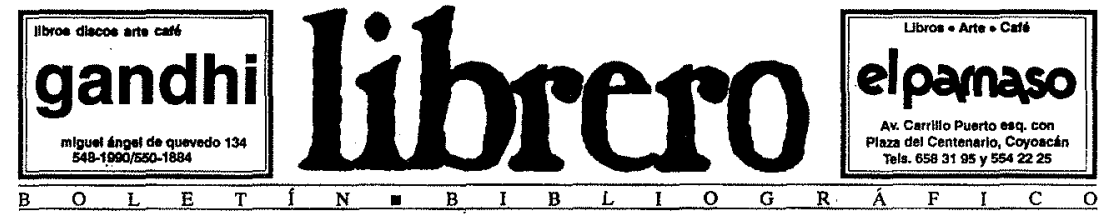

AIESEC es un esfuerzo organizado y dinámico para encontrar la solución a sus problemas por medio de su programa de prácticas gerenciales a nivel internacional. Cuarenta y dos años a nivel internacional y veintisiete años de experiencia en México nos respaldan.

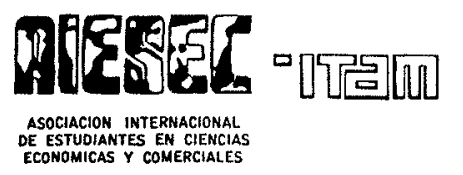

AIESEC-ITAM

Río Hondo \# 1 Col. Tizapán

San Angel 01000 México D.F

Tel. -550-9300 al 01 ext. 125

Fax.- 548-5620 At'n. AIESEC

Telex.- 1775725 PTECME At'n. AIESEC

Para mayores informes contacte con nosotros:

Bitnet.-AIESEC@ITAMVMS1

\section{Revista de}
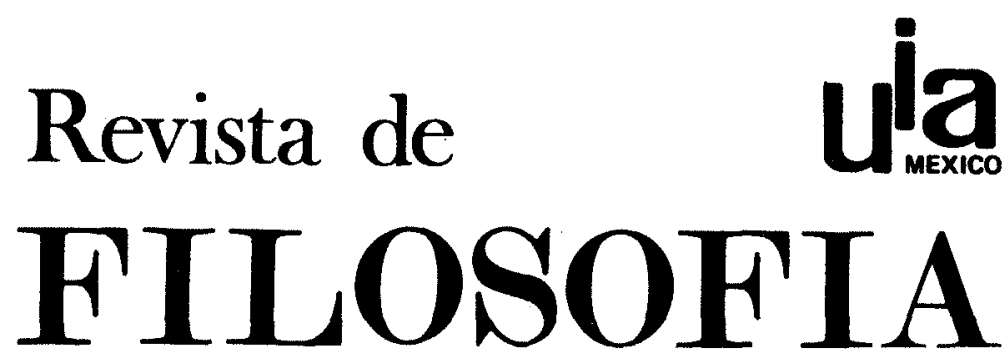

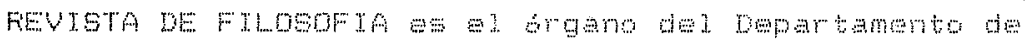

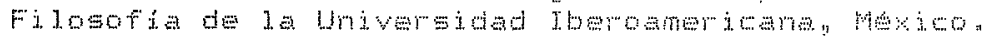

Foses periodicided cuatrimestral desoe 1960.

Dirigia pot rose Fuber samabria

Consejo edtorial. Tuan Manuel Silva $y$

Jorge: Agurre Bala.

Thromarion y correspondermin it

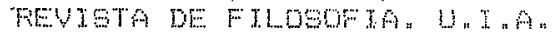

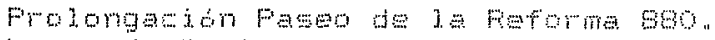

Lomas de Ganta Fe, Del. A "Dregen.

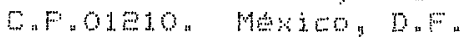




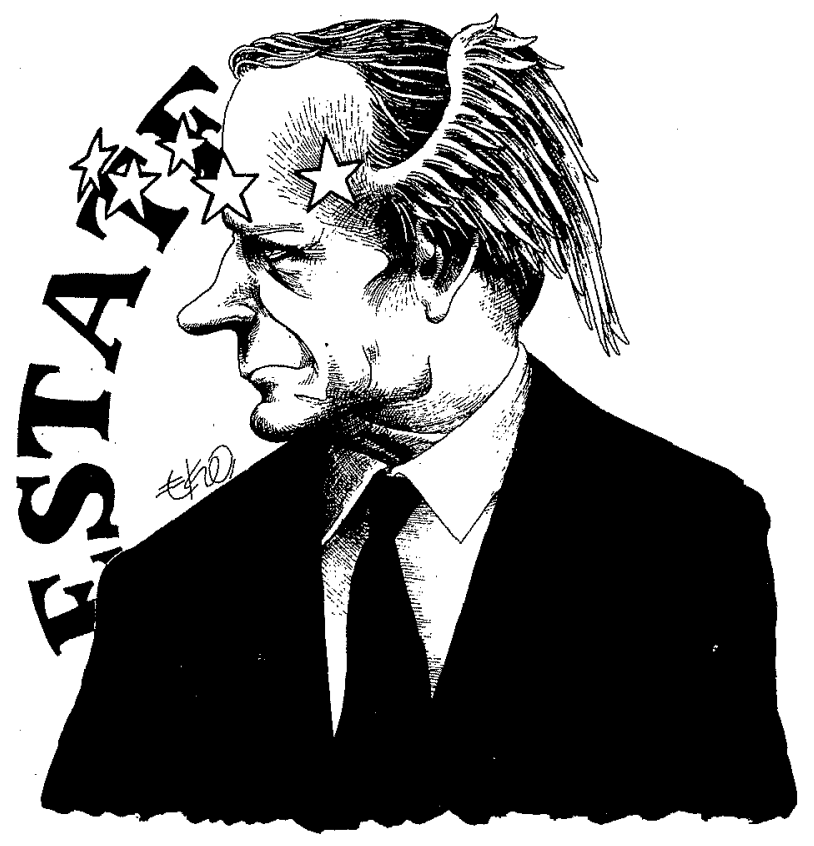

\section{Ios hechos se comentan de muchas maneras.}

\section{unomásuno juzgue decida.}




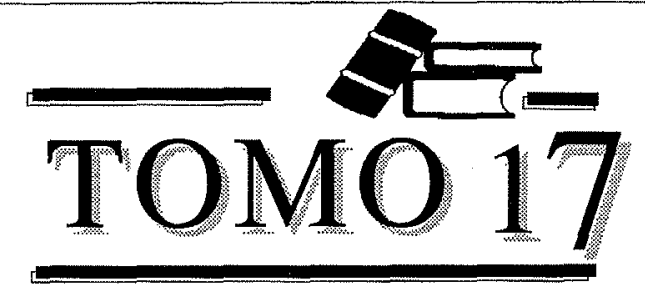

Una librería nueva de todo a todo

\section{Atención Personal}

Cafetería y Estacionamiento

Insurgentes Sur 2090

San Angel, a un costado

del monumento a

Alvaro Obregón

\section{QUESO PAN Y VINO, S. A.}

Desayunos a Partir de las 7:30 A.M.

i NUEVOS PLATILLOS !

AV. DE LA PAZ No. 40-106 SAN ANGEL 660-22-57.

\section{BUENA MESA Y AMIGOS}




\section{El Colegio de México} PUBLICACIONES

Blanca Torres (coord.)

Interdependencia: ¿un enfoque útil para el anślisis de las relaciones México-Estados Unidos?

Ilán Bizberg

Estado y sindicalismo en México

Lorenzo Meyer (comp.)

México-Estados Unidos, 1988-1989

Francisco Zapata

Ideología y política en América Iatina

Soledad Loaeza y Claudio Stern (coords.)

Las clases medias en la coyuntura actual

Victor Islas Rivera

Estructura y desarrollo del sector transporte en México

Departamento de Publicaciones

Camino al Ajusco 20, Pedregal de Sta. Teresa 10740 México, D.F. Telefono 5686033 exts. 297 y 388

\section{Los autores del Fondo ENRIQUE FLORESCANO}

Ensayos sobre el desarrollo económico de México y América Latina (1500-1975)

Los seis ensayos que tratan el caso de México hacen énfasis en los momentos de transición y cambio que afectaron a la economfa durante el largo periodo que va del siglo $\mathrm{XV}$ al $\mathrm{XIX}$, o intentan explicar las características básicas de la estructura económica y definir sus componentes, o ambas cosas.

\section{De venta en librerías}

\section{$\frac{c}{e}$}

Fondo de Cultura Económica

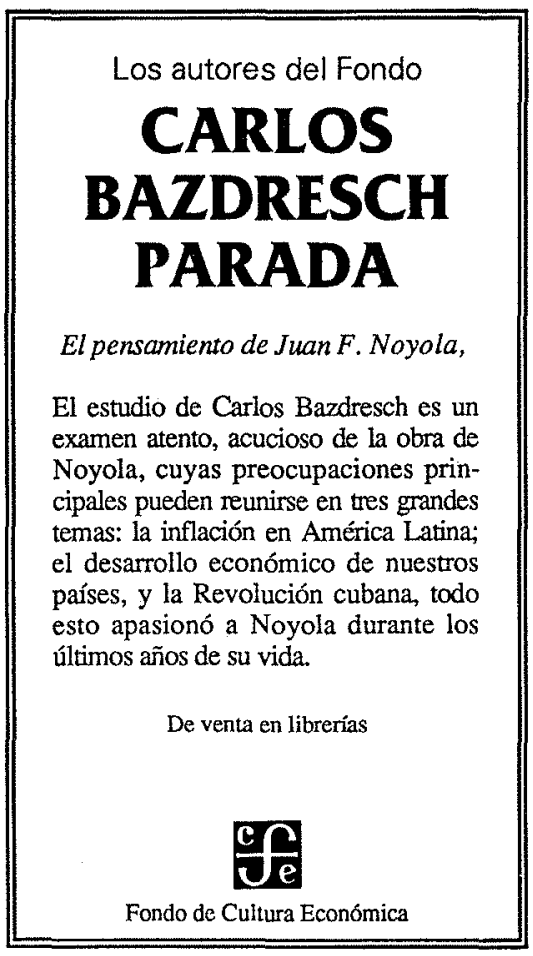




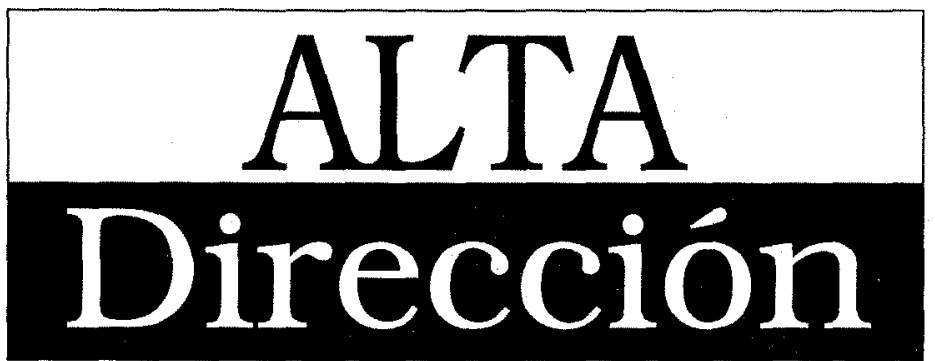

La Revista de Análisis y Desarrollo Gerencial

\section{" Información bimestral para todo el año"}

Suscripciones y Venta Publicitaria:

Hamburgo 306-B

Colonia Juárez. 06600 México D.F.

Telefono: 2865590
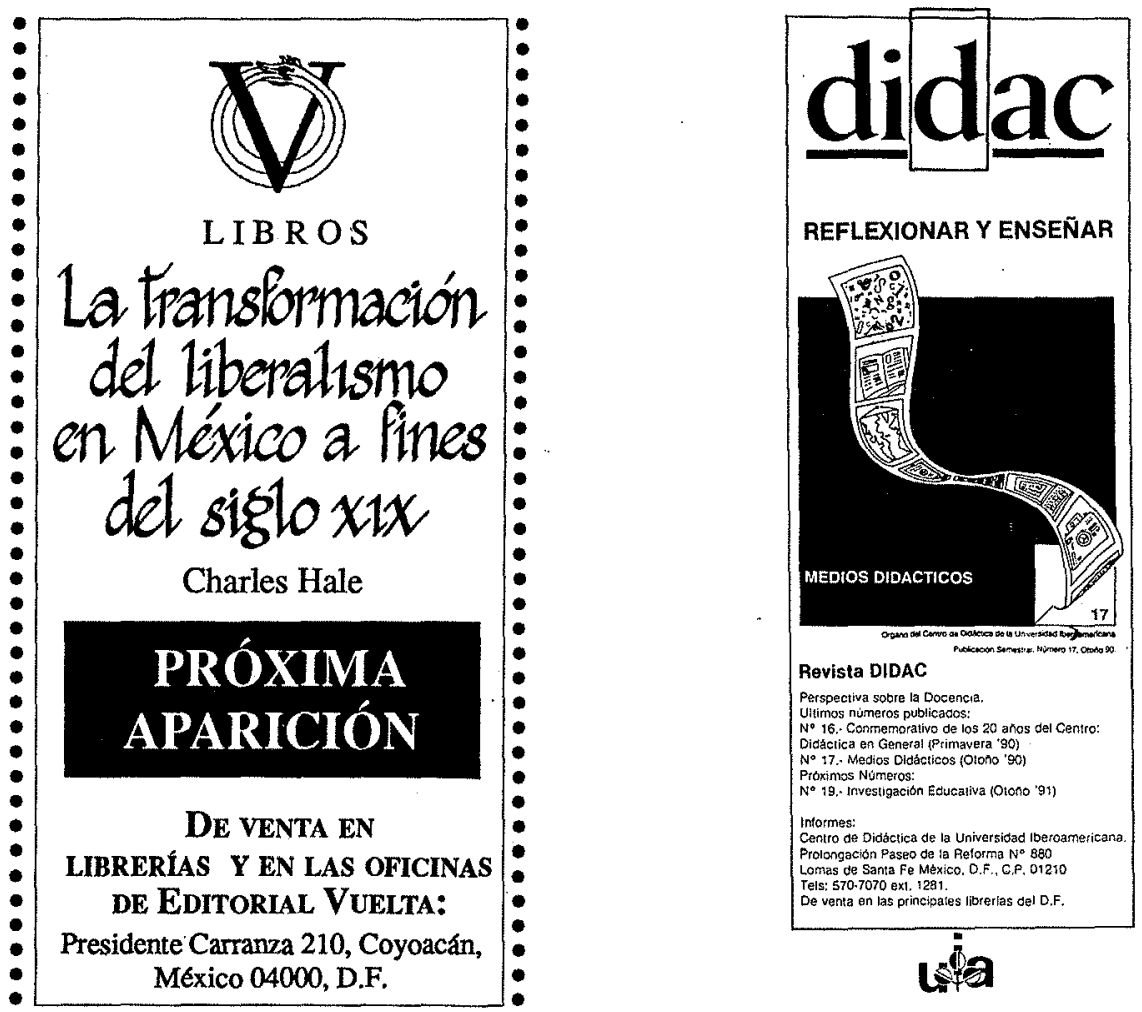


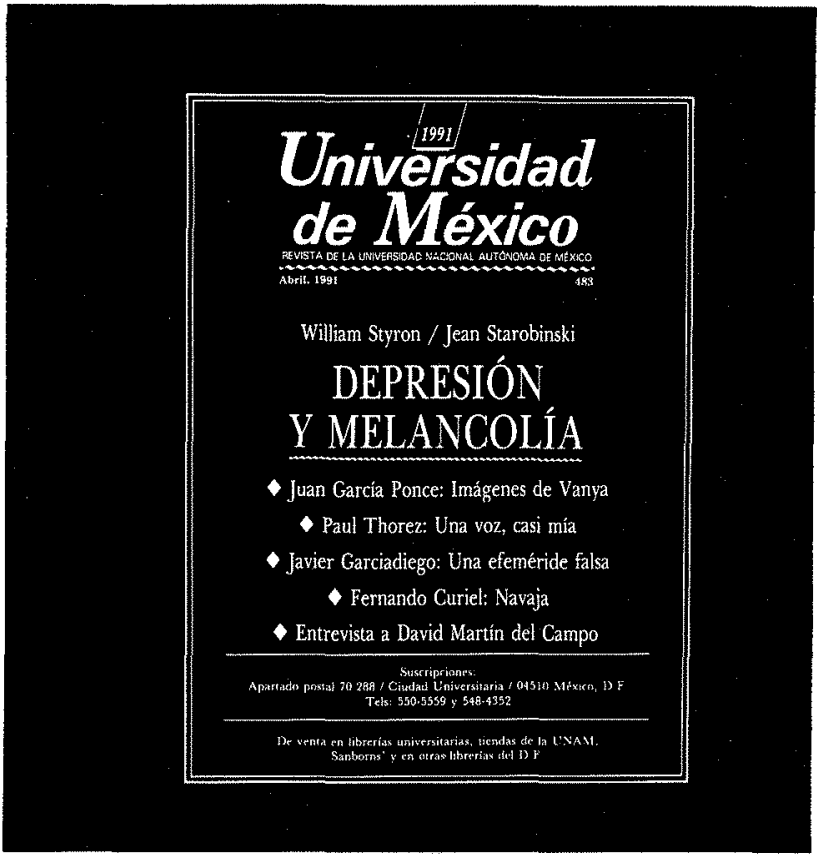

\section{CENTRE D'ÉTUDES MEXICAINES ET CENTRAMÉRICAINES}

Colección de Documentos para la Historia de Nayarit, Jesn Meyer ed, y autor tomos II a V. Thomas Calvo, autor tomo I

I Los albores de un nuevo mundo, siglos xvi-xvI, Dos siglos críticos en los que los habitantes de la costa y del plan estuvieron sometidos a la Conquiste mientras que los nayaritas del este y del oeste se dedicaban a resistir la integración al sistema colonial, refugiándose en el Nayar (es el periodo menos conocido y más importante por ser la matriz del mundo por venir).

II Nuevas mutaciones: el siglo xvitr. Siglo de luz y sombra, de mucho movimiento, en esa tierra fronteriza de la dinámica Nueva Gaticia. Siglo de expansión territorial y de proyección imperial; se funda San Blas, "Gibraltar de las Américas" como pieza clave en el control del Paćfico, de las Californias y del lejano norocste amenazado por los cosacos nisos.

III El Gran Nayar. "Reducido y pacificado en 1722" es la región serrana de los coras y huicholes, mexicaneros y otros grupos indigenas. Historia de las misiones jesuitas y franciscanas; de la aculturación y de la resistencia violenta y pacífica de los indios nayaritas; del conflicto entre los jesuitas y el Estado borbonico.

IV Le Tierra de Manuel Lozada. Historia agraria de todo el siglo Xtx; historia político-militar en cuanto está ligada a los problemas de tierras y comunidades. La segunda parte está dedicada a Manuel Lozada, líder agrario, político y militar entre 1853 y 1873 , y verdadero fundador del estado de Nayarit.

V De cantón de Tepic a estado de Nayaril, 1810-1940. Jean Meyer y Alicia Hernández

Remite al tomo IV al que complementa en los aspectos demogrăficos, economicos y sociales. Se le da mucha atención al puerto de San Blas factor decisivo en la prosperidad y autonomización de la zona. La segunda parte trata de la revolución de independencia, del porfiriato $y$ de la Revolución.

Trace 18. Centroamerica después de Esquipulas II

Seis autotes centroamericanos y tres franceses estudian la crisis político militar en sus dimensiones intemas y externas, globales y pecutiares a cada pars. A la guerra de "baja intensidad", corresponden "las democracias de baja intensidad".

La mitad del mundo, cuerpo y cosmos en los rituales otomies. Jacques Galinier, coedición con la UNAM y el INI, 746 págs.

Análisis de las correspondencias entre la concepción de los actos rituales, la imagen del cuerpo y la vision del mundo de los otomíes en el sur de la Huasteca. Se ilumina el sentido profundo de las "costumbres", de la devoción a los muertos y del camaval, el díálogo tenebroso del sexo y de la muerte.

CEMCA, Sierra Leona 330, 11000 Méxleo DF, tels, $5405921 / 5405922$, FAX 5405923. 


\section{ESTUDIOS}

Puntos de venta en la ciudad de México

ARGHIVO GENERAL DE LA NACIÓN • CASA DEL LIBRO • BUÑUEL • EU REKA • FONDO DE CULTURA ECONÓMICA • IBERO • EL PARNASO • PRADO • EL RELOX • SOR JUANA • MULTIPAPELERIA ERMITA • EDICIONES QUINTO SOL • GRANÉN PORRÚA • ZAPLANA • TAB (HOTEL JENA, MOCEL) • E.N.A.H. GANDHI • EL GALLO ILUSTRADO. INTERACADÉMICA • PARROQUIAL DEL SUR - POLANCO • DEL SÓTANO • SALVADOR ALLENDE • EL JUGLAR • ÁBACO • DE TODO • MARTI • MADERO • TOK'S • AMOXTLI • C.I.D.E. - GATESA • COLEGIO DE MEXICO • SUPER LIBRO (PERISUR) • U.A.M. • POLIFORUM GULTURAL SIQUEIROS • BRITANICA • FRANGESA - BIBLIOGRAFICA • NUEVO CONCEPTO • FERNANDO PORRUA • CENTRO, (SAN ANGEL) •

Búsquela también en las principales ciudades de toda la República

CUPÓN DE SUSCRIPCIÓN (Use letra de imprenta)

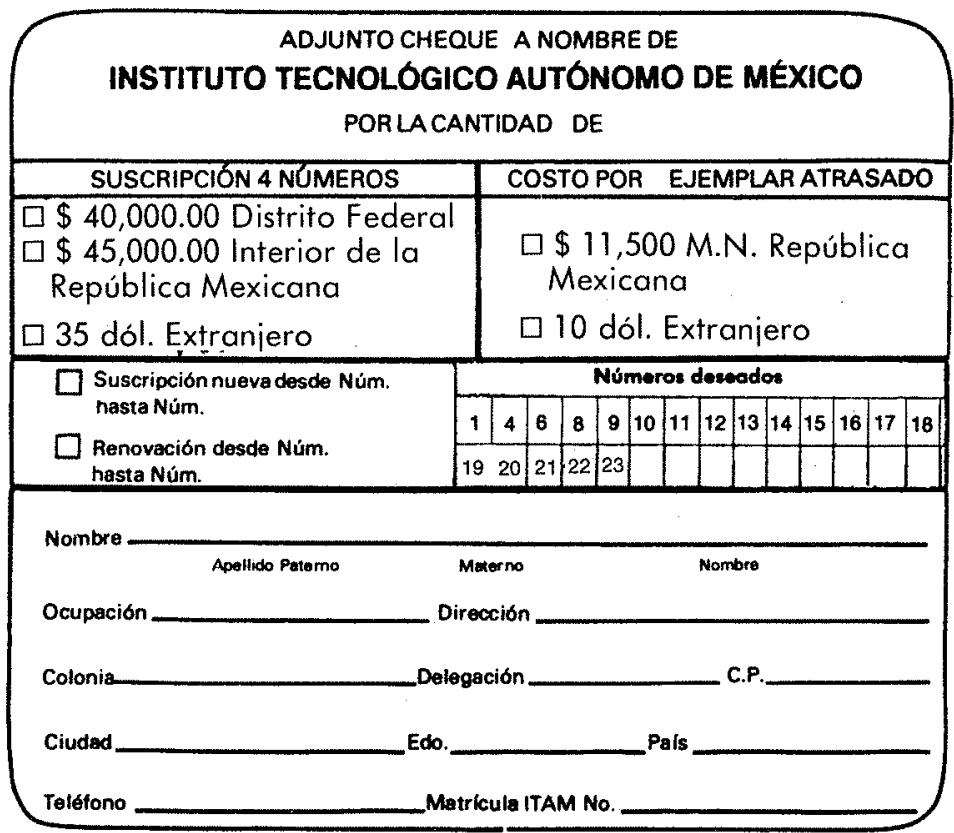




\section{Nuevo Centro [l] de Investigación y Estudios de Posgrado}
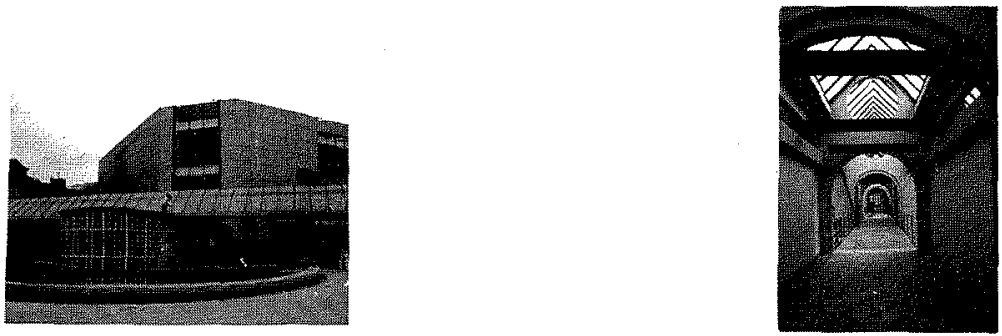

Investigación, excelencia académica, pluralidad
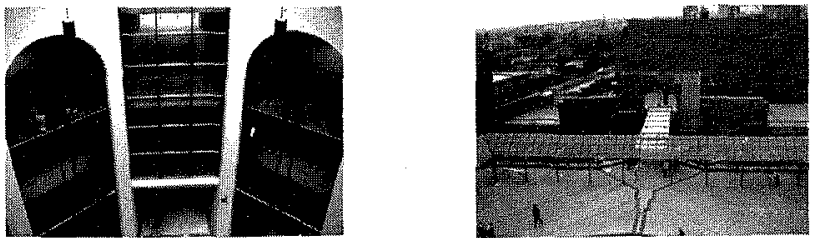

43 años contribuyendo al desarrollo integral de una sociedad más libre y más justa
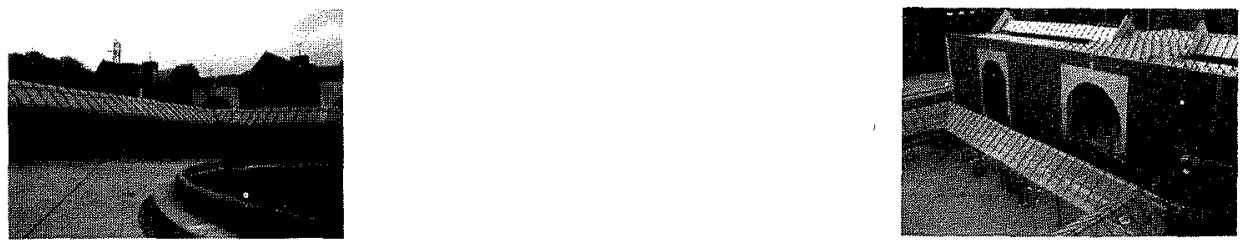

INSTITUTO TECONOLÓGICO AUTÓNOMO DE MÉXICO

NUEVO PLANTEL:

Camino de Santa Teresa No. 930

Col. Héroes de Padierna

Delegación Magdalena Contreras, C.P. 10700

México, D.F.

Tel. 5683099 


\section{CITAM Derechos Reservados.}

La reproducción total o parcial de este artículo se podrá hacer si el ITAM otorga la autorización previamente por escrito.
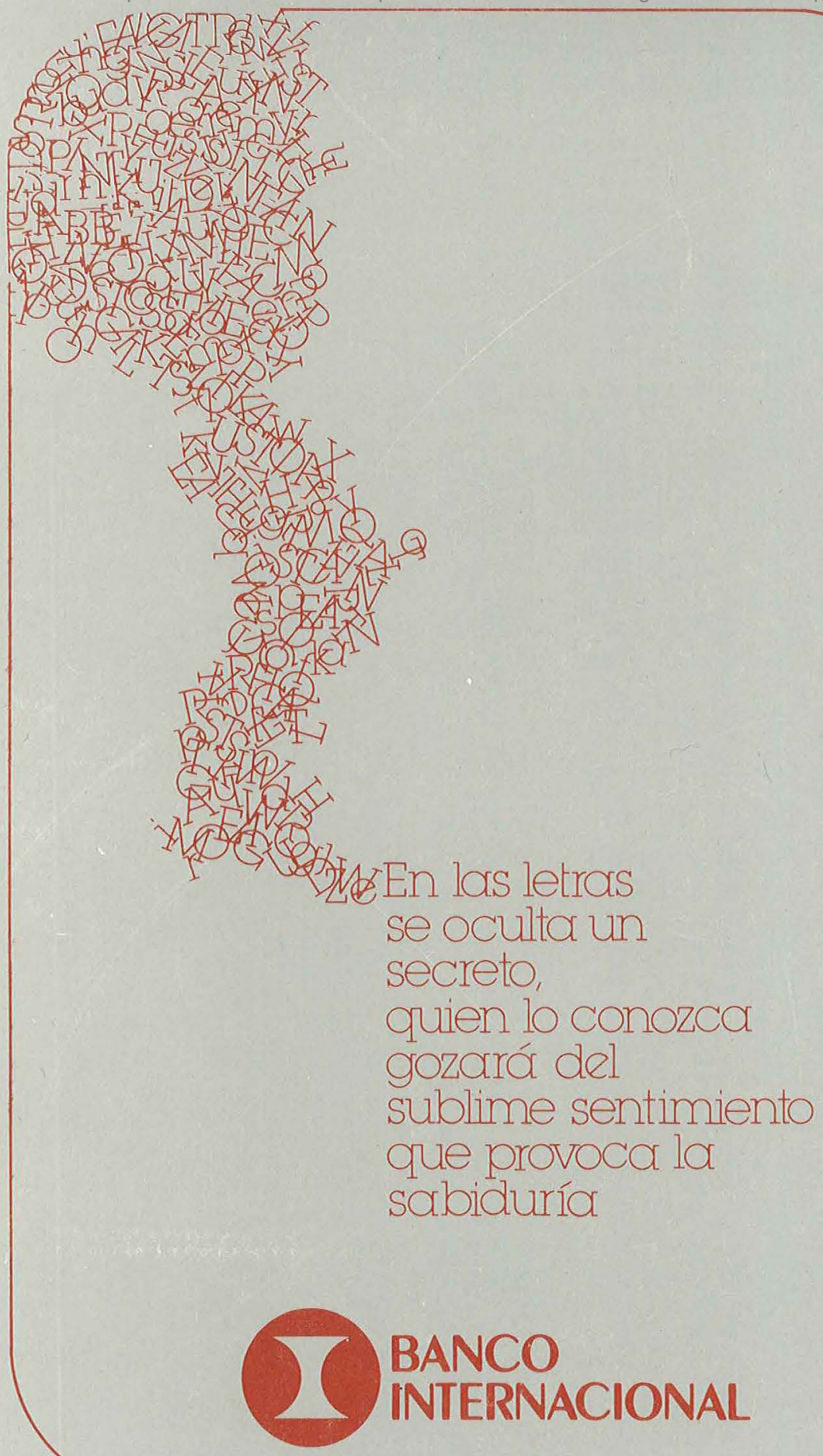